\title{
A 60-million-year Cenozoic history of western Amazonian ecosystems in Contamana, eastern Peru
}

Pierre-Olivier Antoine ${ }^{\mathrm{a}, *}$, M. Alejandra Abello ${ }^{\mathrm{b}, \mathrm{c}}$, Sylvain Adnet ${ }^{\mathrm{a}}$, Ali J. Altamirano Sierra ${ }^{\mathrm{d}}$, Patrice Baby ${ }^{\mathrm{e}, \mathrm{f}}$, Guillaume Billet $^{\mathrm{g}}$, Myriam Boivin a ${ }^{\text {, Ysabel Calderón }}{ }^{\mathrm{e}, \mathrm{f}}$, Adriana Candela ${ }^{\mathrm{h}}$, Jules Chabain ${ }^{\mathrm{a}}$, Fernando Corfu ${ }^{\mathrm{i}}$, Darin A. Croft ${ }^{\mathrm{j}}$, Morgan Ganerød ${ }^{\mathrm{k}}$, Carlos Jaramillo ${ }^{1}$, Sebastian Klaus ${ }^{\mathrm{m}}$, Laurent Marivaux ${ }^{\mathrm{a}}$, Rosa E. Navarrete ${ }^{\mathrm{n}}$, Maëva J. Orliac ${ }^{\mathrm{a}}$, Francisco Parra ${ }^{\mathrm{e}, \mathrm{n}}$, María Encarnación Pérez ${ }^{\mathrm{o} p}$, François Pujos ${ }^{\mathrm{q}}$, Jean-Claude Rage ${ }^{\mathrm{g}}$, Anthony Ravel ${ }^{\mathrm{a}}$, Céline Robinet ${ }^{\mathrm{a}, \mathrm{h}}$, Martin Roddaz ${ }^{\mathrm{e}}$, Julia Victoria Tejada-Lara ${ }^{\mathrm{d}, \mathrm{r}, \mathrm{s}}$, Jorge Vélez-Juarbe ${ }^{\mathrm{t}, \mathrm{u}}$, Frank P. Wesselingh ${ }^{\mathrm{v}}$, Rodolfo Salas-Gismondi ${ }^{\mathrm{a}, \mathrm{d}}$

a Institut des Sciences de l'Evolution, UMR 5554 CNRS, IRD, EPHE, Université de Montpellier, Place Eugène Bataillon, 34095 Montpellier cedex 5, France

b Laboratorio de Sistemática y Biología Evolutiva (LASBE), Museo de la Plata, Paseo del Bosque s/n, B1900FWA La Plata, Argentina

c Consejo Nacional de Investigaciones Científicas y Técnicas (CONICET), Argentina

${ }^{\mathrm{d}}$ Museo de Historia Natural-Universidad Nacional Mayor San Marcos, Departamento de Paleontología de Vertebrados, Avenida Arenales 1256, Lima 11, Perú

e Géosciences-Environnement Toulouse, Université de Toulouse, UPS (SVT-OMP), LMTG, CNRS, IRD, 14 Avenue Édouard Belin, F-31400 Toulouse, France

${ }^{f}$ Convenio IRD-PeruPetro, Av. Luis Aldana 320, San Borja, Lima, Peru

g Sorbonne Universités, CR2P, MNHN, CNRS, UPMC-Paris 6, Muséum national d'Histoire naturelle, CP 38, 8 rue Buffon, 75231 Paris cedex 05, France

${ }^{\text {h }}$ División Paleontología Vertebrados, Museo de la Plata, Paseo del Bosque s/n, B1900FWA La Plata, Argentina

i Department of Geosciences, University of Oslo, P.O. Box 1047 Blindern, NO-0316 Oslo, Norway

j Department of Anatomy, School of Medicine, Case Western Reserve University, Cleveland, OH 44106, USA

${ }^{\mathrm{k}}$ Geological Survey of Norway, 7491 Trondheim, Norway

${ }^{1}$ Center for Tropical Paleoecology and Archeology, Smithsonian Tropical Research Institute, Balboa, Ancon AA 0843-03092, Panama

${ }^{m}$ Department of Ecology and Evolution, J.W. Goethe University, Max-von-Laue-Str. 13, 60438 Frankfurt a. M., Germany

${ }^{\mathrm{n}}$ Paleosedes E.U. Tv 27 n57-49 Campin, Bogotá, Colombia

${ }^{\circ}$ CONICET, Museo Paleontológico Egidio Feruglio, Av. Fontana 140, Trelew, Argentina

${ }^{\mathrm{p}}$ Field Museum of Natural History, 1400 Lake Shore Drive, Chicago, IL, USA

${ }^{q}$ IANIGLA, CCT-CONICET-Mendoza, Avenida Ruiz Leal s/n, Parque General San Martín, 5500 Mendoza, Argentina

${ }^{\mathrm{r}}$ Department of Earth and Environmental Sciences, Lamont Doherty Earth Observatory of Columbia University, Palisades, NY 10964, USA

${ }^{s}$ Division of Vertebrate Paleontology, American Museum of Natural History, NY 10024, USA

${ }^{\mathrm{t}}$ Department of Mammalogy, Natural History Museum of Los Angeles County, Los Angeles, CA, USA

u Department of Paleobiology, National Museum of Natural History, Smithsonian Institution, Washington, DC, USA

v Naturalis Biodiversity Center, P.O. Box 9517, 2300 RA Leiden, Netherlands

\section{A R T I C L E I N F O}

\section{Article history:}

Received 5 July 2015

Received in revised form 23 October 2015

Accepted 5 November 2015

Available online 12 November 2015

Handling Editor: M. Santosh

\section{Keywords:}

Fossil record

Paleobiology

Stratigraphy

Paleogeography

South America

\begin{abstract}
A B S T R A C T
We provide a synopsis of $\sim 60$ million years of life history in Neotropical lowlands, based on a comprehensive survey of the Cenozoic deposits along the Quebrada Cachiyacu near Contamana in Peruvian Amazonia. The 34 fossilbearing localities identified have yielded a diversity of fossil remains, including vertebrates, mollusks, arthropods, plant fossils, and microorganisms, ranging from the early Paleocene to the late Miocene-?Pliocene $(>20$ successive levels). This Cenozoic series includes the base of the Huchpayacu Formation (Fm.; early Paleocene; lacustrine/fluvial environments; charophyte-dominated assemblage), the Pozo Fm. (middle + ?late Eocene; marine then freshwater environments; most diversified biomes), and complete sections for the Chambira Fm. (late Oligocene-late early Miocene; freshwater environments; vertebrate-dominated faunas), the Pebas Fm. (late early to early late Miocene; freshwater environments with an increasing marine influence; excellent fossil record), and Ipururo Fm. (late Miocene-?Pliocene; fully fluvial environments; virtually no fossils preserved). At least 485 fossil species are recognized in the Contamana area ( 250 'plants', 212 animals, and 23 foraminifera). Based on taxonomic lists from each stratigraphic interval, high-level taxonomic diversity remained fairly constant throughout the middle Eocene-Miocene interval (8-12 classes), ordinal diversity fluctuated to a greater degree, and family/species diversity generally declined, with a drastic drop in the early Miocene. The Paleocene-?Pliocene fossil assemblages from Contamana attest at least to four biogeographic histories inherited from (i) Mesozoic Gondwanan times, (ii) the Panamerican realm prior to (iii) the time of South America's
\end{abstract}

\footnotetext{
* Corresponding author.

E-mail address: pierre-olivier.antoine@umontpellier.fr (P.-O. Antoine).
} 
Cenozoic "splendid isolation", and (iv) Neotropical ecosystems in the Americas. No direct evidence of any North American terrestrial immigrant has yet been recognized in the Miocene record at Contamana.

(c) 2015 International Association for Gondwana Research. Published by Elsevier B.V. All rights reserved.

\section{Contents}

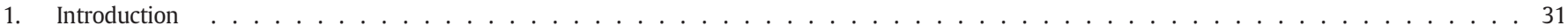

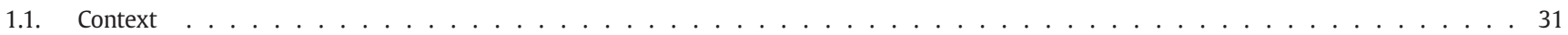

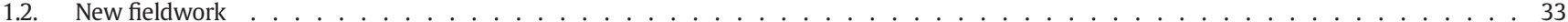

2. Material and methods . . . . . . . . . . . . . . . . . . . . . . . . . . . . 35

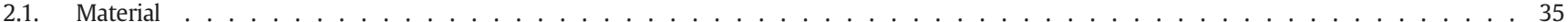

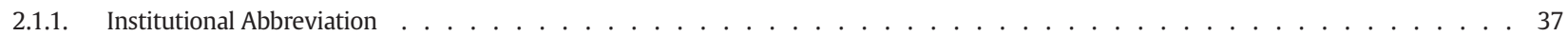

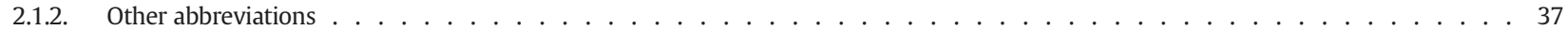

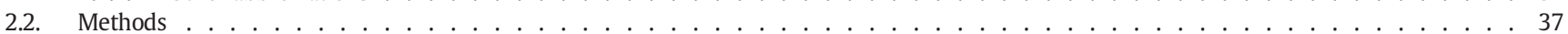

2.2.1. Lithostratigraphy . . . . . . . . . . . . . . . . . . . . . . . . . . . 37

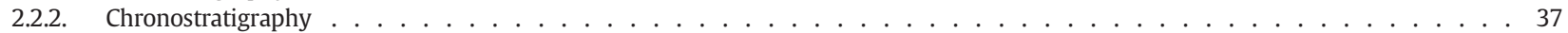

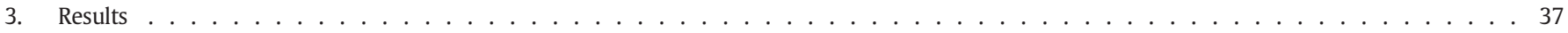

3.1. Lithostratigraphic units and fossil assemblages . . . . . . . . . . . . . . . . . . . . . . . . . . . . . . 37

3.1.1. Huchpayacu Formation (Paleocene) . . . . . . . . . . . . . . . . . . . . . . . . 37

3.1.2. Pozo Formation, Lower Member; 'Pozo Sands' (middle and ?late Eocene interval) . . . . . . . . . . . . . . . . . . . . . . . . 38

3.1.3. Chambira Formation (Oligocene-?early Miocene) . . . . . . . . . . . . . . . . . . . . . . . . . . . . . . . . 40

3.1.4. Pebas Formation (late early to early late Miocene interval) . . . . . . . . . . . . . . . . . . . . . . . . . 44

3.1.5. Ipururo Formation (late Miocene-?early Pliocene) . . . . . . . . . . . . . . . . . . . . . . . . . . . . . . 48

3.1.6. Ucayali Formation (?late Pliocene-Pleistocene) $\ldots \ldots \ldots \ldots$

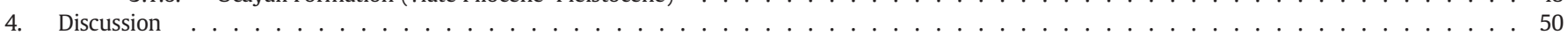

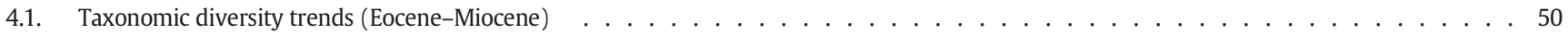

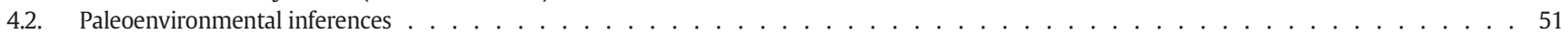

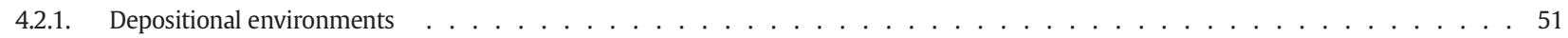

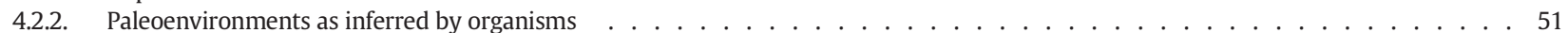

4.2.3. Correlation with other Amazonian sub-basins . . . . . . . . . . . . . . . . . . . . . . . 5 51

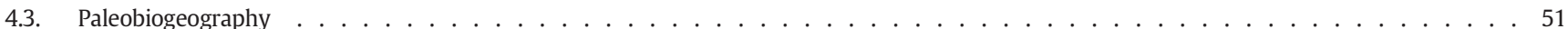

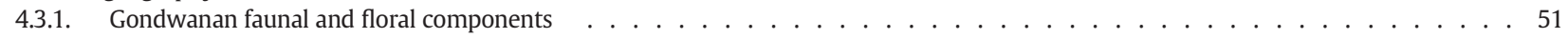

4.3.2. Panamerican heritage (and Holarctic outliers) ． . . . . . . . . . . . . . . . . . . . . . . . . . . . 52

4.3.3. South American endemics . . . . . . . . . . . . . . . . . . . . . . . . . . . . . . . 52

4.3.4. Neotropical markers - no evidence for the Great American Biotic Interchange . . . . . . . . . . . . . . . . . . . . 53

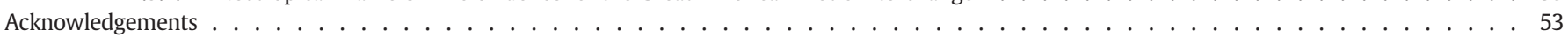

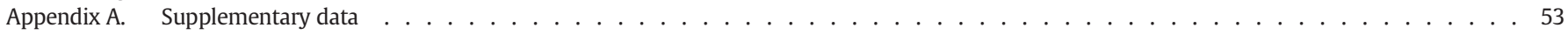

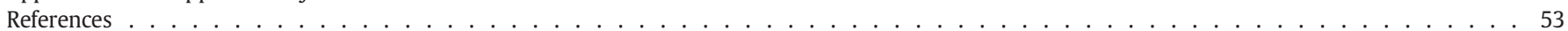

The heavy vegetation in the jungles of eastern Peru conceals rock exposures; travel is possible only along trails; the best and only place to study the geology is along stream beds.

[Kummel (1948: 1221)]

\section{Introduction}

\subsection{Context}

The Cenozoic fossil record of northern (tropical-equatorial) South America, particularly the Paleogene interval, consists almost exclusively of small numbers of specimens from scattered outcrops with generally poor age constraints (for a review, see Hoorn and Wesselingh, 2010; Hoorn et al., 2010a). In contrast to the Patagonian steppe or Andean highlands (see Flynn et al., 2012), intense vegetation cover, severe surface weathering, and seasonal flooding in Amazonia widely hamper access to extensive exploitable outcrops throughout most of this region.

The first fossils reported from Amazonia were Miocene mollusks from Pebas in Eastern Peru (Gabb, 1869; Woodward, 1871), a small village east of Iquitos, Loreto Department (Fig. 1A) which subsequently gave its name to both a Miocene formation and the gigantic corresponding megawetlands system (see Hoorn et al., 2010b for a review). Subsequently, blue clays and lignite seams from this Miocene formation were extensively investigated for pollen (e.g., Hoorn, 1993, 1994), fish (Monsch, 1998), and mollusks (e.g., Wesselingh et al., 2002, 2006; Wesselingh and Ramos, 2010). The first fossil insects and mites from western Amazonia were uncovered in amber fragments originating from a late middle Miocene lignite level of the Iquitos area (Antoine et al., 2006; Petrulevičius et al., 2011; Perrichot et al., 2014). More recently, a species-rich crocodylomorph assemblage (seven species, including three new taxa of shell-crushing caimans) was described from the same seam (Salas-Gismondi et al., 2014, 2015).

Very few descriptions of fossil vertebrates from other areas of Amazonian lowlands in Peru were published before the 1980s (Anthony, 1924; Patterson, 1942; Spillmann, 1949; Willard, 1966; Buffetaut and Hoffstetter, 1977). By contrast, many field campaigns were organized in the 1980s and 1990s to search for Neogene and Pleistocene vertebrates, especially mammals, along the Madre de Dios/Acre River (Fig. 1A; Frailey, 1986). Perhaps the most notable discovery of these campaigns was Amahuacatherium peruvium, a gomphotheriid proboscidean of disputed affinities and age, which was unearthed from an outcrop of the Madre de Dios River, near its confluence with the Los Amigos River (=Cerro Colorado section; Campbell et al., 2000, 2001; Alberdi Alonso et al., 2004; Ferretti, 2008; Campbell et al., 2010; Mothé and Avilla, 2015). Located in a high cliff with extensive landslides, the concerned section ranges from the late Miocene to the late Pleistocene, as constrained by magnetostratigraphy (Campbell et al., 


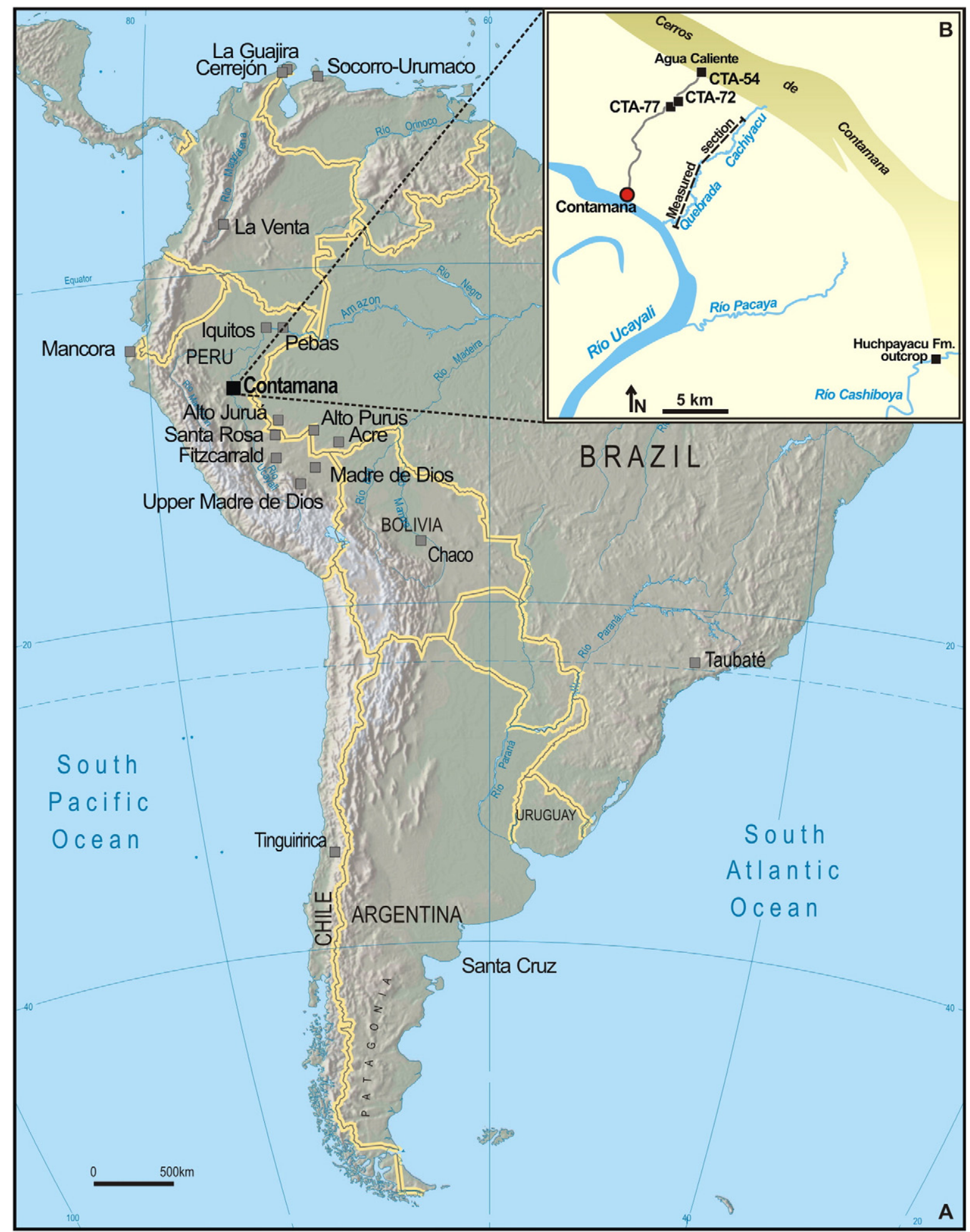

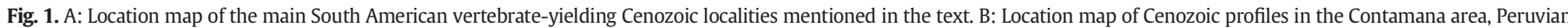
Amazonia.

2010), radioisotopy, and geomorphology (Olivier et al., 2009). A Pleistocene thorny bamboo, referred to as Guadua sp., was recognized in blue clays $6 \mathrm{~m}$ below the top of the same cliff (Olivier et al., 2009).

The discovery of the Santa Rosa locality, in eastern Peru (Fig. 1A) represented a real milestone in the paleontology of Amazonian lowlands, as it included the first indisputable species-rich Paleogene vertebrate assemblage from Proto-Amazonia. It led to the publication of a monograph (Campbell, 2004), mainly focusing on mammals, that described rodents (Frailey and Campbell, 2004), marsupials (Goin and Candela, 2004), a possible gondwanathere (Goin et al., 2004), bats (Czaplewski and Campbell, 2004), and notoungulates (Shockey et al., 2004). It also yielded cingulate xenarthrans, described by Ciancio et al. (2013), and the earliest and basalmost South American primate described thus far (Bond et al., 2015). In the absence of any temporal constraint other than mammalian biochronology (which has been difficult given that most Santarosan taxa are unique to that site), the age of 
this locality remains unclear: it may be either "?late Eocene" (e.g., Bond et al., 2015) or, more probably, early Oligocene (Shockey et al., 2004; Croft et al., 2009: 197; Antoine et al., 2012; Kay, 2015).

In the last decade, field efforts were also undertaken in the Fitzcarrald Arch (Fig. 1A), the topographic high bordering upper Amazonian sub-basins (see Espurt et al., 2010). These field campaigns enabled the discovery of a rich and diversified vertebrate fauna, assigned to the late middle Miocene Laventan South American Land Mammal Age (SALMA), and dominated by mammals, fish, and crocodylomorphs ('Fitzcarrald Local Fauna'; Salas-Gismondi et al., 2006; Antoine et al., 2007; Salas-Gismondi et al., 2007; Negri et al., 2010; Goillot et al., 2011; Pujos et al., 2013; Tejada-Lara et al., 2015). Concurrently, the same multidisciplinary team surveyed the upper Madre de Dios River (Fig. 1A), leading to the recognition of an early middle Miocene mammal assemblage ("Colloncuran" SALMA; Antoine et al., 2013), as well as an early Miocene mammalian faunule that is noteworthy for producing the earliest crown platyrrhine known so far (MD-61, "Pinturan" age; Marivaux et al., 2012), and an early middle Miocene mammal assemblage ("Colloncuran" SALMA; Antoine et al., 2013). Microfossils (foraminiferans), macrofossils (oysters and selachians), geochemical, and sedimentological evidence from the area document the occurrence of a (late) Paleocene marine incursion in the Southern Peruvian Foreland Basin (SPFB; Louterbach et al., 2014). A large early Eocene xenungulate mammal, of both Patagonian and eastern Brazilian affinities, was recently recovered in northwestern coastal Peru, further indicating that South American subaerial areas formed a single biogeographic realm in early Paleogene times (Máncora locality, Fig. 1A; Antoine et al., 2015).

The first pre-Pleistocene fossils from Brazil consisted of remains of the giant Miocene caiman Purussaurus, which were collected from the Alto Purus River banks in the late $19^{\text {th }}$ century (Fig. 1A; BarbosaRodrigues, 1892). Since then, the Amazonian fossil record near the Brazilian-Peruvian border has been widely explored by intense fieldwork along the Madre de Dios River, the Purus River, and in the Alto Juruá (Fig. 1A). Published works focus mainly on vertebrates (Paula-Couto, 1956; Simpson and Paula-Couto, 1981; Frailey, 1986; Kay and Frailey, 1993; Cozzuol, 2006; Kay and Cozzuol, 2006; Negri et al., 2010; Ribeiro et al., 2013; Kerber et al., 2015), mollusks, and ostracods (Muñoz-Torres et al., 2006; Wesselingh et al., 2006; Wesselingh and Ramos, 2010; Gross et al., 2013).

In Colombia, fossils found at the Cerrejón Coal Mine (Cerrejón Fm., Guajira; Fig. 1A) include fossil leaves, seeds, fruits and a diverse record of pollen and spores (Jaramillo et al., 2007; Doria et al., 2008; Herrera et al., 2008; Wing et al., 2009). This locality also yielded the most complete and diverse middle-late Paleocene ( $59 \mathrm{Ma})$ tropical South American fauna (e.g., Cadena, 2014). This assemblage notably encompasses a giant snake (Head et al., 2009), crocodiles (Hastings et al., 2010, 2011), and turtles (Cadena et al., 2010). Regarding vertebrates, chelonian remains are by far the most abundant for the Paleogene interval in Colombia (e.g., upper Paleocene Bogotá Fm.; lower Oligocene Mugrosa Fm.; upper Oligocene Tuné Fm.; Cadena, 2014). The Neogene period is mostly documented in two distinct areas, near the Colombian-Venezuelan border (La Guajira Peninsula; Fig. 1A; fluviolacustrine to marine environments; lower-middle Miocene UitmaJimol-Castilletes formations; e.g., Moreno et al., 2015) and in the Huila Department (La Venta area; fluviolacustrine environments; middle Miocene Villavieja and La Victoria formations; e.g., Stirton, 1953; Kay and Madden, 1997). The middle Miocene La Venta fauna is one of the few diverse Cenozoic vertebrate faunas in tropical South America (Fig. 1A; e.g., Hirschfeld and Marshall, 1976; MacFadden, 1990; Lundberg, 1997; Madden et al., 1997; MacFadden, 2006). The fossil mammals consist of marsupials, xenarthrans, rodents, astrapotheres, litopterns, toxodonts, typotheres, primates, sirenians, and bats (Kay and Madden, 1997; Czaplewski et al., 2003). Mollusk, arthropod, and vertebrate faunas from La Guajira Peninsula and the Socorro-Urumaco formations in Venezuela (Fig. 1A) further indicate the presence of biotic connections between the paleo-Amazonas-Orinoco system and coastal areas of Colombia-Venezuela during Neogene times (Sánchez-Villagra et al., 2000, 2004; Sánchez-Villagra and Scheyer, 2010; Rincón et al., 2014; Hendy et al., 2015; Jaramillo et al., 2015; Moreno et al., 2015; Salas-Gismondi et al., 2015; Vallejo-Pareja et al., 2015).

In contrast with the Andean highlands (for a review, see Flynn et al., 2012), little work has been done on the Cenozoic fossil record of Amazonian lowlands from Bolivia (e.g., Hulka et al., 2006; Uba et al., 2009; Tineo et al., 2015) or Ecuador (e.g., Tschopp, 1953).

Most of these localities represent a series of snapshots in the history of Proto-Amazonia and/or glimpses into the evolutionary history of a given taxonomic group, which are not easily correlated temporally, although synthetic works have begun to pave the way for broader analyses: see Hoorn (1993) and Jaramillo et al. (2011) for Neogene and Cenozoic palynostratigraphy, respectively; Wesselingh et al. (2006) for Miocene mollusks; Sheppard and Bate (1980), Muñoz-Torres et al. (1998), Ramos (2006), Wesselingh and Ramos (2010), or Gross et al. $(2013,2014)$ for ostracods and/or foraminifers; Lovejoy et al. (1998, 2006), Monsch (1998), Brito and Deynat (2004), Brito et al. (2007), and Lundberg et al. (2010) for fish evolution and distribution; Negri et al. (2010) for mammals and birds; Hovikoski et al. (2010), Lundberg et al. (2010), Boonstra et al. (2015) for sedimentological and paleontological arguments of Miocene marine incursions.

The region of Contamana, in Loreto, Peruvian Amazonia (Fig. 1A-B), is a notable exception among localities in the Amazonian basin. Today, Contamana is located in the North Amazonian foreland basin, NW of the Fitzcarrald Arch, and near the Ucayali River (Fig. 1). Due to Andean tectonics, this area is folded with NW-SE structures (Fig. 2), which provides access to a thick stratigraphic section documenting an extremely long and continuous sedimentary record (Jurassic-Holocene), unparalleled Amazonia. The section was thoroughly described and measured for "petroleum prospects" by the Comisión Geológica de la Montaña during the 1940s in two distinct zones, i.e. along the Cushabatay River and along the Cachiyacu River (as Quebrada Cachiyacu; Kummel, 1948). Nevertheless, the fossils of these areas, which were suggested to be rich and diverse (Kummel, 1948), were never collected nor properly described. For instance, the paleontological appendix of the Contamana area geological map (Lipa et al., 1997) only lists a single charophyte assemblage, originating from an early Paleogene interval (Fig. 1A; see Section 3.1.1; Romero-Pittman in Lipa et al., 1997).

\subsection{New fieldwork}

Since 2008, a multidisciplinary international team has made annual expeditions to the Contamana area, with the aim of comprehensively surveying the Cenozoic deposits along the Quebrada Cachiyacu. This long-term survey resulted in the discovery of scattered outcrops on mud trails and on the new road to Quebrada Agua Caliente (Figs. 1A2 ). In total, at least 34 fossil-yielding localities have been identified, that have yielded fossil remains of vertebrates (fish, amphibians, sauropsids, and mammals) as well as mollusks, arthropods (ostracods and crustaceans), plant fossils (palynomorphs, charophytes, seeds, fruits, and silicified wood), microorganisms (foraminiferans, poriferans, and algae), and dinoflagellates, as listed in the Supplementary Data. In a single continuous section on the SW flank of the Maquía Anticline, we recognize 20 successive fossil-bearing levels, ranging from the middle Eocene up to the late Miocene-?Pliocene, in the SW flank of the Maquia Anticline (Fig. S1). The main characteristics of all concerned localities are detailed in the Table 1.

Two recent studies by our team have focused on a fossil-rich level from the Quebrada Cachiyacu (namely CTA-27; Figs. 2-3), that is late middle Eocene in age, around the Lutetian-Bartonian transition. To date, this locality has yielded both the earliest South American hystricognathous rodents (stem Caviomorpha; Antoine et al., 2012) and freshwater stingrays (Potamotrygonidae; Adnet et al., 2014). Yet, the thanatocoenoses of other levels from the same area have yet to be described and characterized. 


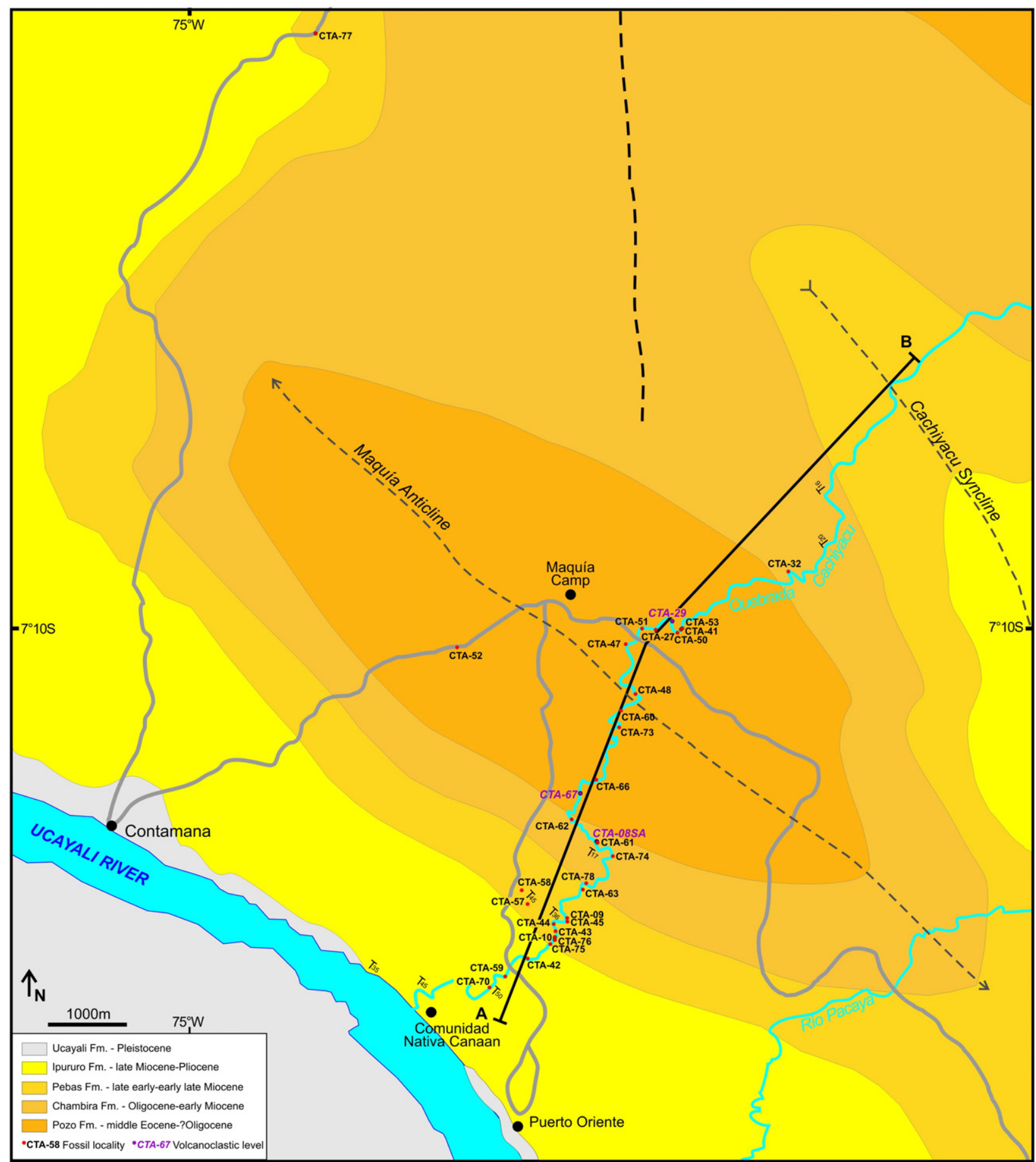

A

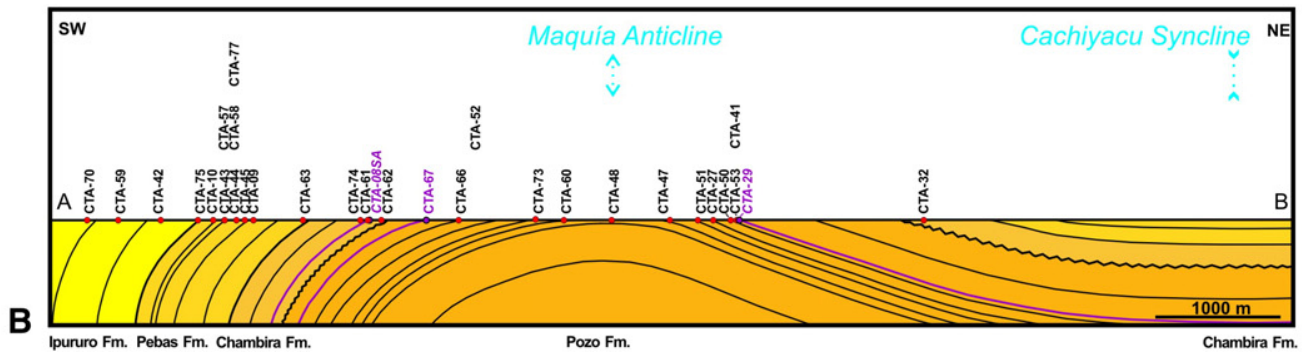

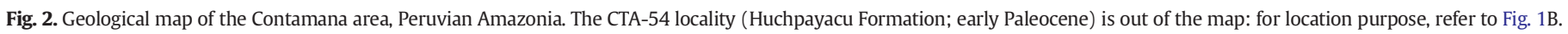
Modified from Lipa et al. (1997). 
Table 1

Location of Cenozoic fossil-yielding localities and other outcrops of interest nearby Contamana, Peruvian Amazonia.

\begin{tabular}{|c|c|c|c|c|c|}
\hline Locality & Lat. (S) & Long. (W) & Formation, member & Hypothesized/constrained age & Depositional environment \\
\hline CTA-08SA & 7.35421 & 74.95375 & Chambira & $26.56 \pm 0.07 \mathrm{Ma}(\mathrm{U} / \mathrm{Pb}$ on zircons $)$ & Distal ash, fluvial setting \\
\hline CTA-09 & 7.36361 & 74.95708 & Pebas & Late early-early middle Miocene & Fluvial setting \\
\hline CTA-10 & 7.36538 & 74.95812 & Pebas & Late Miocene & Fluvial setting \\
\hline CTA-27 & 7.33011 & 74.94733 & Pozo, lower member & Late middle Eocene & Fluvial setting \\
\hline СТА-29 & 7.32859 & 74.94556 & Pozo, lower member & Late middle Eocene & Fluvial setting \\
\hline CTA-32 & 7.32374 & 74.93284 & Chambira, base & Late Oligocene & Oxbow lake \\
\hline CTA-41 & 7.32923 & 74.94468 & Pozo, lower member & Late middle Eocene & Fluvial setting \\
\hline CTA-42 & 7.36743 & 74.96035 & Ipururo & Late Miocene-Pliocene & Fluvial setting \\
\hline CTA-43 & 7.36497 & 74.95793 & Pebas & Earliest late Miocene (Mayoan) & Tidal interface \\
\hline CTA-44 & 7.36415 & 74.95833 & Pebas & Middle-late Miocene transition & Coastal channel, marine influence \\
\hline CTA-45 & 7.36388 & 74.95708 & Pebas & Middle Miocene & Coastal channel, tidal influence \\
\hline CTA-47 & 7.33113 & 74.95127 & Pozo, lower member & Middle Eocene & Fluvial setting, marine influence \\
\hline CTA-48 & 7.33632 & 74.95067 & Pozo, lower member & Middle Eocene & Floodplain \\
\hline CTA-49 & 7.33522 & 74.95158 & Pozo, lower member & Middle Eocene & Floodplain \\
\hline CTA-50 & 7.32957 & 74.94492 & Pozo, lower member & Late middle Eocene & Fluvial setting \\
\hline CTA-51 & 7.32948 & 74.9492 & Pozo, lower member & Late middle Eocene & Fluvial setting \\
\hline CTA-52 & 7.33193 & 74.9707 & Pozo, lower member & Late middle Eocene & Floodplain \\
\hline CTA-53 & 7.32921 & 74.94461 & Pozo, lower member & Late middle Eocene & Fluvial setting \\
\hline CTA-54 & 7.2147 & 74.94937 & Huchpayacu, lower member & Paleocene & Lacustrine setting \\
\hline CTA-57 & 7.36191 & 74.96111 & Pebas & Earliest late Miocene (Mayoan) & Oxbow lake \\
\hline CTA-58 & 7.36004 & 74.96223 & Pebas & Middle-late Miocene transition & Marine setting/mangrove \\
\hline CTA-59 & 7.36878 & 74.96551 & Ipururo & Latest Miocene-Pliocene & Fluvial setting \\
\hline CTA-60 & 7.33964 & 74.95255 & Pozo, lower member & Middle Eocene & Fluvial setting \\
\hline CTA-61 & 7.35448 & 74.95366 & Chambira, base & Late Oligocene & Fluvial setting \\
\hline CTA-62 & 7.35335 & 74.95573 & Chambira, base & Late Oligocene & Fluvial setting \\
\hline CTA-63 & 7.36053 & 74.95551 & Pebas, base & Early Miocene (Colhuehuapian) & Lacustrine setting, marine influence \\
\hline CTA-65 & 7.32893 & 74.94551 & Pozo, lower member & Late middle Eocene & Fluvial setting \\
\hline CTA-66 & 7.34876 & 74.95431 & Pozo, lower member & Late middle Eocene & Fluvial setting \\
\hline CTA-67 & 7.35015 & 74.95563 & Yahuarango top & Late middle Eocene & Distal ash, fluvial setting \\
\hline CTA-72 & 7.25116 & 74.97200 & Chambira/Pebas & Late Oligocene-early Miocene? & Floodplain \\
\hline CTA-73 & 7.34160 & 74.95241 & Pozo, lower member & Late middle Eocene & Fluvial setting \\
\hline CTA-74 & 7.35618 & 74.95241 & Chambira & Late Oligocene & Fluvial setting \\
\hline CTA-75 & 7.36596 & 74.95855 & Pebas, top & Late Miocene (Mayoan-Chasicoan) & Fluvial setting \\
\hline CTA-76 & 7.36553 & 74.95818 & Pebas & Late Miocene & Estuarine embayment \\
\hline CTA-77 & 7.25229 & 74.97757 & Pebas & Middle-late Miocene transition & Marine setting/mangrove \\
\hline CTA-78 & 7.35988 & 74.95498 & Chambira top & ?Early Miocene & Floodplain deposit, terra firme \\
\hline SYNCL-CACH & 7.30093 & 74.92073 & ?Pebas & ?Miocene & Fluvial setting \\
\hline
\end{tabular}

Based on this unrivalled paleontological corpus, the current work documents $\sim 60$ million years of life history in the Neotropical lowlands (early Paleocene to ?Pliocene), with a focus on the biotas and their physical environment, spanning the final stages of Proto-Amazonia and the onset of modern Amazonia.

\section{Material and methods}

\subsection{Material}

All fossils described in the present work were found in-situ by our team in the Contamana area, while prospecting or excavating during the 2008-2014 field campaigns (see Supplementary Data). Small remains (microvertebrates, arthropods, mollusks, and charophytes) were collected by screening-washing of rock samples ranging from $200 \mathrm{~g}$ (preliminary tests) up to ca. $850 \mathrm{~kg}$ (e.g., CTA-27, CTA-32, CTA-61, CTA-44, and CTA-43), with a $0.7 \mathrm{~mm}$ and/or $1 \mathrm{~mm}$ and/or $2 \mathrm{~mm}$ mesh. We have not used acid etching, in order to preserve delicate calcified shells (foraminiferans, mollusks, ostracods, and crabs). Each and every specimen recognized a priori as belonging to a fossil organism was collected in the field, then adequately preserved, and subsequently studied by the team member(s) with the greatest experience working with the relevant taxonomic group. Taxa already described from the Cachiyacu section (rodents [Antoine et al., 2012] and freshwater stingrays from CTA-27 [Adnet et al., 2014]) will not be described herein, but the corresponding results will be included in the discussion. Specimens were tentatively identified at species level whenever possible. Nonetheless, many of them have a formal taxonomic assignment only at a higher taxonomic level (see
Supplementary Data). Specimens that were left in open nomenclature are either $(i)$ lacking diagnostic features (often due to their fragmentary state) or (ii) likely to document new taxa to be described in the near future in dedicated papers, an undertaking far beyond the scope of the present work. The specimens are stored in the Museo de Historia Natural, Universidad Nacional Mayor de San Marcos, Lima, Perú (MUSM).

Localities (termed CTA-XX and numbered in the order in which they were recognized in the field) were named separately when consisting of distinct outcrops. In very few cases, lateral equivalents were subsequently and unambiguously recognized based on geometrical and/or lithostratigraphical and/or paleontological correspondences between close exposures (e.g., CTA-41 and CTA-53 or CTA-44 and CTA-58; Fig. 3). In few other cases, distinct stratigraphic levels were distinguished within a single thick exposure, where distinct depositional environments were suspected to occur (i.e., marine-influenced vs. fluvial settings in CTA-44). Fossil-yielding levels usually are $10 \mathrm{~cm}$ up to 50 $\mathrm{cm}$-thick. None of them is more than $1 \mathrm{~m}$-thick. The hypothesized sedimentation rates as calculated by Roddaz et al. (2010: Table 5.2) for the Northern Peruvian foreland basin are around $1 \mathrm{~mm} / \mathrm{year}$. As a consequence, time-averaging within a given locality is likely negligible, especially given that the complete fossil-yielding series is ca. 2,800 m-thick, with a continuous record exceeding $1,300 \mathrm{~m}$ for the middle Eocene-?Pliocene interval (Fig. 3).

Upper case letters are used for the upper dentition (I, incisor; C, canine; P, premolar; M, molar; D, decidual tooth) and lower case letters for lower dentition (i, incisor; c, canine; p, premolar; m, molar; d, decidual tooth). All measurements are given in millimeters, except where noted otherwise. 


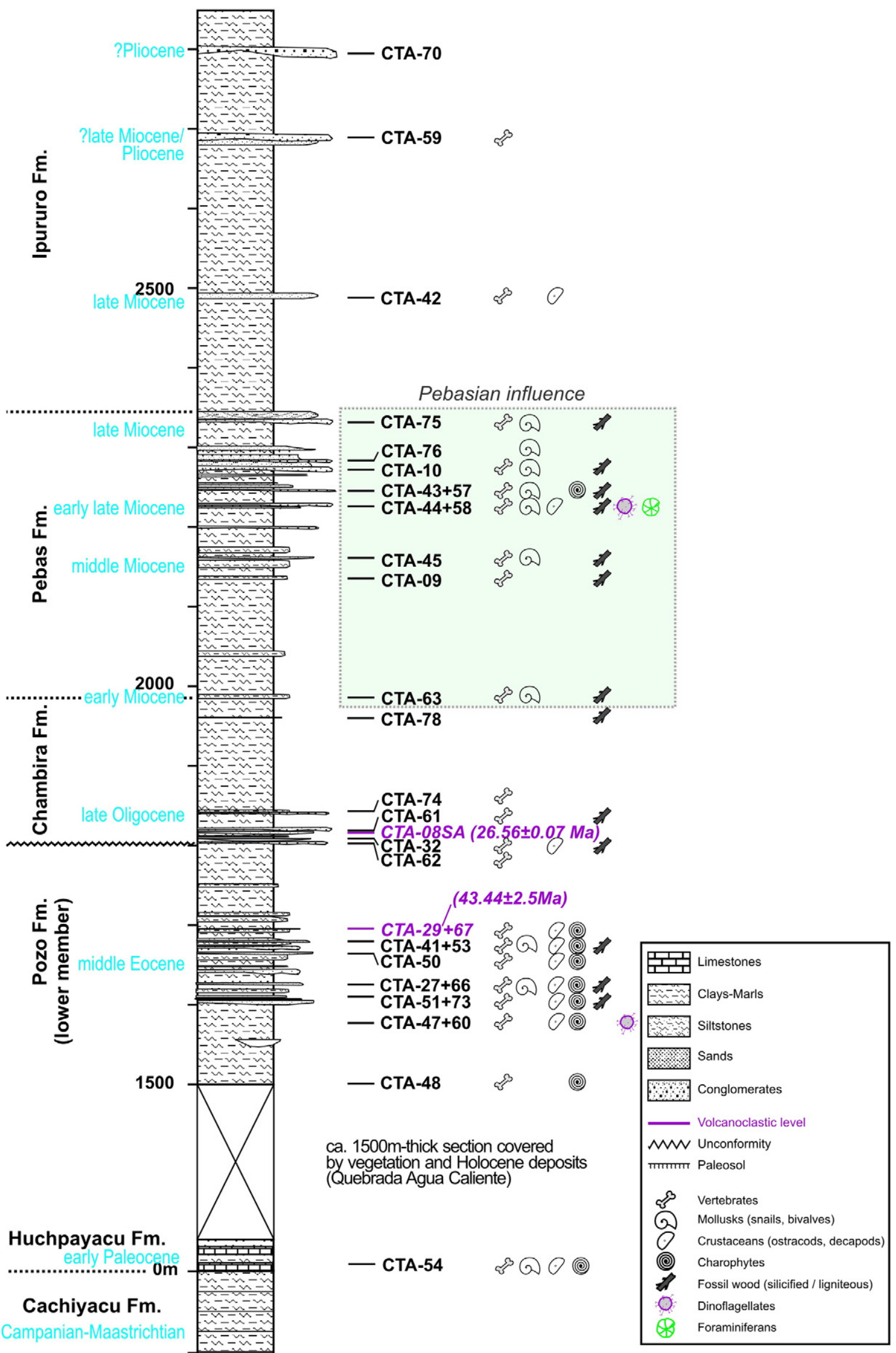

Fig. 3. Synthetic section of Cenozoic deposits in the Contamana area, Peruvian Amazonia. See Fig. S1 for more information on hypotheses for correlation. 


\subsubsection{Institutional Abbreviation}

MUSM, Museo de Historia Natural de la Universidad Nacional Mayor San Marcos, Lima, Perú.

\subsubsection{Other abbreviations}

FAD, First Appearance Datum; FLO, First Local Occurrence; Fm., Formation; GABI, Great American Biotic Interchange; LAD, Last Appearance Datum; LLO, Last Local Occurrence; NPFB, Northern Peruvian foreland basin; PMWS, Pebas Mega-Wetland System; SALMA, South American Land Mammal Age; SPFB, Southern Peruvian foreland basin.

\subsection{Methods}

\subsubsection{Lithostratigraphy}

The nomenclature of Cenozoic formations from the Contamana area mostly follows that proposed in the seminal monograph by Kummel (1948) and subsequent works (e.g., Christophoul et al., 2002; Hermoza et al., 2005; Roddaz et al., 2010 and references therein; Louterbach et al., 2014).

\subsubsection{Chronostratigraphy}

The chronostratigraphy for the Cenozoic deposits of Contamana (Quebrada Agua Caliente and Quebrada Cachiyacu sections) was achieved by combining biochronological proxies (nanofossils: dinoflagellates; microfossils: spores and pollen, charophytes, foraminiferans, and ostracods; macrofossils: mollusks and vertebrates) and radioisotopic data ( $\mathrm{Ar} / \mathrm{Ar}$ on feldspars; $\mathrm{U} / \mathrm{Pb}$ on zircon grains).

2.2.2.1. Biochronological proxies. All fossil specimens we have collected in-situ during 2008-2014 were regarded $a$ priori as potentially useful in a biostratigraphical perspective. The concerned specimens were then investigated independently by specialists of the corresponding taxonomic groups. Biochronological inferences were provided agnostically, discussed in detail, and then synthesized to be presented here. In most cases, geo- and biochronological results derived from the different taxonomic groups were consistent. Nevertheless, some Contamana assemblages appear to document novel co-occurrences of taxa, a situation analogous to that described for faunas such as Tinguiririca, Chile (an early Oligocene site interposed between the Mustersan and Deseadan SALMAs; Flynn et al., 2003) (Fig. 1A) and potentially Los Sapos, Argentina (an Eocene site possibly interposed between the Riochican and Vacan SALMAs; Tejedor et al., 2009). This is particularly true for charophytes, mollusks, decapods, or vertebrates.

Palynostratigraphy has been used as the main biostratigraphic tool by numerous oil companies and researchers in the region over the last 50 years, with excellent results (Germeraad et al., 1968; Regali et al., 1974; Bayona et al., 2008; Jaramillo et al., 2009). The palynological zones used in the region (Germeraad et al., 1968; Lorente, 1986; Muller et al., 1987; Hoorn, 1993; Jaramillo et al., 2011) have been calibrated with planktonic foraminifera and carbon isotope stratigraphy (Germeraad et al., 1968; Muller et al., 1987; Carvajal-Ortiz et al., 2009; Jaramillo et al., 2011).

2.2.2.2. Radioisotopic methods. The tuff CTA-29 (Figs. 2-3) was dated by ${ }^{40} \mathrm{Ar} /{ }^{39} \mathrm{Ar}$ laser step heating on feldspar grains, following a protocol detailed in Antoine et al. (2012). The tuff CTA-08SA (Figs. 2-3) was previously correlated with CTA-29 (Antoine et al., 2012). However, fieldwork performed in 2012-2014 allowed for the discovery of new outcrops, including both fossil-yielding localities (e.g., CTA-66, CTA-73) and ashlevels (e.g., CTA-67). Together with new dating proxies (U/Pb dating of zircon grains from CTA-08SA by one of us [FC]), this additional corpus has enabled us to provide a far more complete scenario for correlating both flanks of the Maquía Anticline (Supplementary Data), and to build up a consistent synthetic section (Fig. 3).

In particular, the age of CTA-29 (NE flank; Fig. 2) has not changed ( $43.44 \pm 2.5 \mathrm{Ma}$, on feldspar grains); this ash is now tentativelycorrelated with CTA-67 (SW flank; Fig. 2), based on all available dating proxies. CTA08SA is located much higher in the stratigraphic section, which is consistent with both its radioisotopic age $(26.56 \pm 0.07 \mathrm{Ma}$; $\mathrm{U} / \mathrm{Pb}$ on zircon grains) and the fossil content of surrounding levels (i.e., CTA-61 and CTA-62, discovered in 2012; Fig. 2).

The CTA-08SA tuff contains zircons that are generally subrounded and with a variety of appearances, suggesting that they are mostly detrital. A selection for analysis was made using zircon crystals that preserve euhedral crystal faces with no evidence of sedimentary damage likely to further coincide with a long gap before deposition. The crystals were treated with chemical abrasion (Mattinson, 2005) to remove effects of secondary $\mathrm{Pb}$ loss, and were then analyzed by ID-TIMS as described for this lab by Corfu (2004). Decay constants are from Jaffey et al. (1971). The analyses, reported in Table S1, indicate that at least five of the grains are detrital: one of them is Precambrian (ca. 1,100 Ma), one is Permian (264 Ma) and the other three are latest Eocene to Oligocene in age. The youngest crystal gives an age of $26.56 \pm 0.07 \mathrm{Ma}$ (Fig. S2; Table S1), which is likely to be close to the time of eruption/deposition.

\section{Results}

\subsection{Lithostratigraphic units and fossil assemblages}

In the following section, formations will be described in stratigraphic order, with a special emphasis on their context, exposures, thickness, paleontological content, inferred time range, and depositional environment(s).

From the bottom up to the top of the Cenozoic series, we have recognized the base of the Huchpayacu Fm. (early Paleocene), the Pozo Fm. (middle + ?late Eocene), and complete sections for the Chambira Fm. (late Oligocene-late early Miocene), the Pebas Fm. (late early to early late Miocene), and Ipururo Fm. (late Miocene-?Pliocene). The Ucayali Fm. (Pleistocene) was not investigated from a paleobiological perspective during our fieldwork. Due to intense surface weathering and vegetation cover, the Casa Blanca Fm. (white sandstones, ?PaleoceneEocene in age; cropping out in the Cushabatay section; Kummel, 1948) could not be identified during our fieldwork.

\subsubsection{Huchpayacu Formation (Paleocene)}

3.1.1.1. Description. In the Contamana area, the lowermost part of the Cenozoic section is only observed in the Agua Caliente section, where gray charophyte-rich marls and limestones crop out in a single $10 \mathrm{~m}$-thick exposure (CTA-54; Fig. 1A; Table 1). It seems to conformably overlie the Campanian-Maastrichtian marine black shales referred to the Cachiyacu Fm. in the same section. This unit was initially described as representing the lowermost strata of the Yahuarango Fm. by Kummel (1948: 1259; "marl, gray, filled with charophytes") and RomeroPittman in Lipa et al. (1997). However, such a succession resembles that depicted by Kummel (1948: 1257) in the Quebrada Cushabatay section $100 \mathrm{~km}$ to the NW and in the Río Cashiboya by Romero Pittman in Lipa et al. (1997), $25 \mathrm{~km}$ to the SE (Fig. 1A). Accordingly, we assign this charophyte-rich level to the Huchpayacu Fm. instead of the Yahuarango Fm.

We were unable to observe the supposedly overlying deposits of the Casa Blanca Fm. (white massive sandstones, 60 m-thick in the Cushabatay area; Kummel, 1948) nor the hypothetic Yahuarango Fm. sensu stricto (see Roddaz et al., 2010 for further discussion), both of which were weathered and completely covered by vegetation. Nevertheless, given the dipping observed for Cenozoic deposits in the concerned sections, the position of the basal Huchpayacu marls and limestones can be estimated at about $1,500 \mathrm{~m}$ below the base of the lowermost levels observed in the Maquía Anticline, and here referred to the Lower Pozo Fm. (Figs. 2-3), i.e. to the Upper Member of the Yahuarango Fm. sensu Kummel (1948) and Antoine et al. (2012). This is in good agreement with the thickness of the corresponding interval, as 
proposed by Kummel (1948) based on direct observation in the "Cerros de Contamana" ( $8 \mathrm{~km}$ further to the NE from the syncline core denoted by "B" in Fig. 2) - a remote zone we did not investigate.

3.1.1.2. Paleontological content (Fig. 4). Screening-washing of $\sim 4.5 \mathrm{~kg}$ of sediment at CTA-54 (Fig. 1A) has allowed for the recovery of thousands of charophyte gyrogonites (Fig. 4), associated with unidentified bone fragments (Vertebrata indet.) and inner casts of gastropods, but no pollen. The corresponding charophyte assemblage includes fourteen taxa, referred to as Chara "Grambastichara" subcylindrica (Fig. 4A), Sphaerochara inconspicua (Fig. 4B), S. huaroensis (Fig. 4C-E), Nitellopsis supraplana sulcata (Fig. 4F-H), N. (Tectochara) merianii (Fig. 4I-J), Peckisphaera cf. portezuelensis / Peckichara sp. (Fig. 4K-M), Peckichara cf. varians (Fig. 4N), Peckichara sp., Pseudolatochara sp., Chara? sp., Lamprothamnium sp., Brevichara sp., Platychara cf. perlata, and Characeae indet. This assemblage includes South American, Gondwanan, and cosmopolitan morphospecies (Table 2).

3.1.1.3. Age. The base of the Huchpayacu Fm. can be constrained only broadly based on the charophyte assemblage of CTA-54 (Table 2). Aside from panchronic taxa, such as Nitellopsis (Tectochara) merianii, Chara? sp., or Brevichara sp., most taxa converge toward a Paleocene age for CTA-54 (Chara "Grambastichara" subcylindrica, Sphaerochara inconspicua, Nitellopsis supraplana sulcata, Peckichara sp., Peckichara cf. varians, Pseudolatochara sp., Lamprothamnium sp.; Mourier et al., 1988; Feist and Brouwers, 1990; Musacchio, 2006; Mebrouk et al., 2009; Vialle et al., 2013). Sphaerochara huaroensis and Platychara cf. perlata have early Paleocene LADs (Jaillard et al., 1993, 1994; Louterbach et al., 2014). Accordingly, the "Sphaerochara Zone" as defined in the Peruvian Andes is early Paleocene in age (Jaillard et al., 1993, 1994), which further supports a Danian age for CTA-54. The co-occurrence of Peckisphaera cf. portezueloensis, of latest Cretaceous affinities (Musacchio, 1973; Chassagne-Manoukian et al., 2013), with several Sphaerochara species (early Paleocene), is not in conflict with this hypothesis.

The charophyte assemblage as described by Romero-Pittman in Lipa et al. (1997) along the Río Cashiboya (Fig. 1B) and including Sphaerochara brevesterensis, Tectochara supraplana supraplana (= Nitellopsis supraplana supraplana), Tectochara ucayalensis ucayalensis, and T. u. gradata, might document the same "Sphaerochara Zone" (Jaillard et al., 1994). Accordingly, we assume an early Paleocene age for this level as well.

There are no charophyte species in common between CTA-54 (Huchpayacu Fm.) and any locality assigned to the Pozo Fm. (Supplementary Data), which further supports the presence of a long stratigraphic gap between both rock units.

3.1.1.4. Depositional environment. The high abundance of charophyte oogonia and the occurrence of grayish limestones and violine marls testify to poorly drained lacustrine and/or fluvial environments, in good agreement with the conclusions of Romero-Pittman in Lipa et al. (1997), at least for the documented outcroup/interval (base of the Huchpayacu Fm. in CTA-54).

3.1.1.5. Correlation. From North to South, comparable formations have been recognized in Northern Peru (Rentema Fm., around Bagua: Mourier et al., 1988; Naeser et al., 1991; in the Huallaga Basin: Hermoza et al., 2005), in Peruvian Andes (around Cuzco: Jaillard et al., 1994), in Southern Peru (Gil et al., 2001), and in Bolivia (Santa Lucía Fm.; e.g., Gayet et al., 2003).

3.1.2. Pozo Formation, Lower Member; 'Pozo Sands' (middle and ?late Eocene interval)

3.1.2.1. Description (Fig. 5). As noticed above, only the lower member of the Pozo Fm. crops out in the Quebrada Cachiyacu profile at Maquía (300 m-thick in the SW flank of the anticline and 500 m-thick in the NE flank; Figs. 2B; S1). However, this interval is widely exposed, as these deposits form the core of the Maquía Anticline (Fig. 2). They consist essentially of red mudstones and variegated paleosols (blue, yellow, red, and purple) with anhydrite veins locally, alternating with scattered inframetric channelized sandstone lenses (Fig. 5A-B), most of which have yielded a diversified fossil content (Fig. 6; Supplementary Data). In exposures such as CTA-51, CTA-27 (Fig. 5B), CTA-29 or CTA-66 (Fig. 5D), these sandstones are massive, gray to yellowish, and unconsolidated. They include millimetric calcareous nodules of diagenetic origin (Fig. 5D), locally encrusting fossil elements (charophyte oogonia, crab claws, fish scales and vertebrate teeth and bones). In some places (e.g., CTA-41), millimetric red clay pebbles occur within microconglomerates.

The concerned unit includes a $30 \mathrm{~cm}$-thick red-brown tuffaceous silty sand exposed in the NE flank of the Maquía Anticline (CTA-29; Figs. 2-3, 5C; S1). It was dated by $\mathrm{Ar} / \mathrm{Ar}$ on feldspar grains (43.44 \pm $2.5 \mathrm{Ma}$; see Antoine et al., 2012) and, based on lithostratigraphy, it is considered to be laterally equivalent to a tuffaceous level cropping out in the SW flank of the Maquía Anticline (CTA-67; Figs. 2-3; S1). No fossil-yielding outcrop referable to the Pozo Fm. was recognized in the Agua Caliente section.

3.1.2.2. Paleontological content (Fig. 6). In the Quebrada Cachiyacu section, 11 fossiliferous outcrops are referred to the Lower Pozo Fm. They document unambiguously nine successive levels (from the base upward, CTA-48, CTA-47 + 60, CTA-51, CTA-27, CTA-73, CTA-50, CTA$41+53$, CTA-29, and CTA-66; Figs. 2-3; S1). Most (if not all) fossiliferous levels yield numerous ostracods (Cypridacea and Cytheracea; e.g., Neocyprideis apostolescui and Ilyocypris aff. lusitanica in CTA-27; Fig. 6G-H) and charophyte gyrogonites (13 taxa, widely dominated by Raskyella pecki meridionale; Fig. 6B-D; Table 2), which strongly contrasts with the overlying deposits from the Chambira, Pebas, and Ipururo Fms. (not a single ostracod recovered, only one charophyteyielding locality; Table 2). The most diversified assemblage is CTA-27 (Antoine et al., 2012; Adnet et al., 2014). It encompasses plant remains (silicified wood chunks and seeds; charcoal; charophytes; Table 2) and palynomorphs (first listed in Antoine et al., 2012). The pollen assemblage from CTA-27 is diverse and well preserved (Table S3). The concerned palynoflora is strictly continental and it indicates a tropical rainforest habitat, with no evidence of savanna vegetation. Palynoflora is composed by a rich diversity of rainforest taxa including Spirosyncolpites spiralis (Fabaceae), Striatopollis catatumbus (Fabaceae), Tetracolporopollenites maculosus (Sapotaceae), Perisyncolporites pokornyi (Malphigiaceae), among many others. The faunal community from CTA-27 includes mollusks (pachychilid gastropods and bivalves; Fig. 6J), crustaceans (ostracods and trichodactylid crabs; Fig. 6I; Yeo et al., 2014), and 49 vertebrate taxa. The concerned vertebrate fauna (Fig. 6L-AF) includes freshwater stingrays (Potamotrygon ucayalensis Adnet et al., 2014), characiform actinopterygians (Fig. 6L-N), anurans (pipid and 'leptodactyloid'), snakes (anilioid and booid), a lizard (platynotan?), chelonians, crocodylomorphs (Sebecus; gavialoid and caimanines; Fig. 6P-Q), a wide array of metatherians (didelphimorphs, sparassodont, bonapartherioid and prepidolopid polydolopimorphians, as well as palaeothentoid paucituberculatans; Fig. 6R-Z), the astegotheriine dasypodid Stegosimpsonia cf. chubutana, five caviomorph rodents, notoungulates, an astrapothere, a litoptern, and a pyrothere (Fig. AC-AE; for further details, see Antoine et al., 2012). Microchiropteran bats are probably also represented, for a total of 26 mammalian taxa (Supplementary Data). One possible gondwanathere tooth from CTA-27 mentioned by Antoine et al. (2012) appears to more likely represent an upper premolar of a polydolopimorphian marsupial. However, two other fragmentary teeth may still pertain to gondwanatheres.

Other localities, either situated below (e.g., CTA-47 [Fig. 5A] or CTA-51) or above CTA-27 in the section (e.g., CTA-29 or CTA-66; Figs. 3, 5C-D) do yield highly analog assemblages (especially regarding charophytes [Table 2], ostracods, potamotrygonid selachians, 


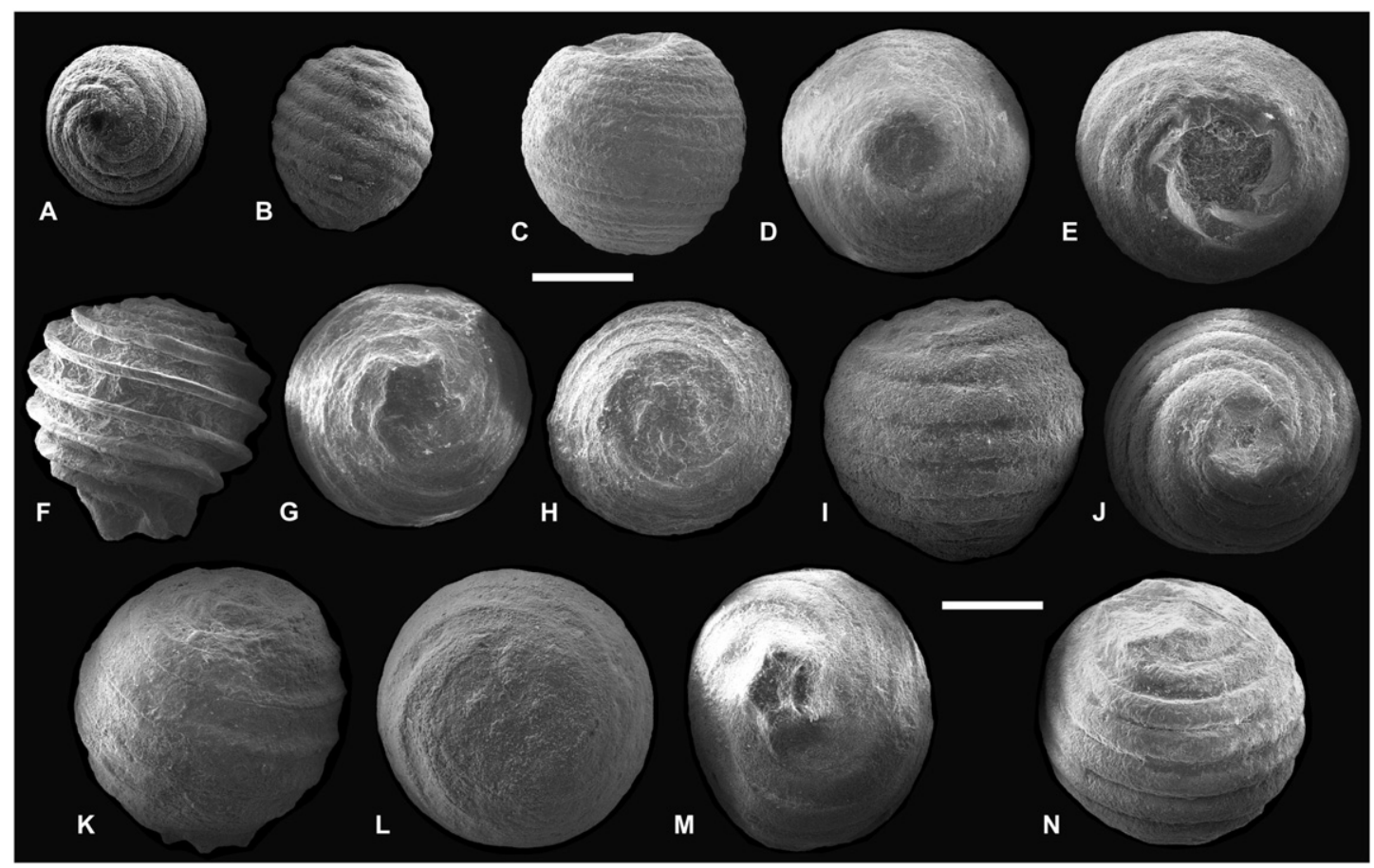

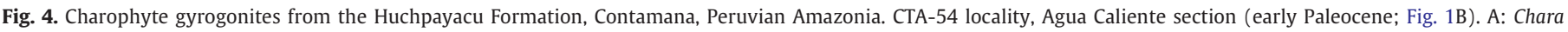

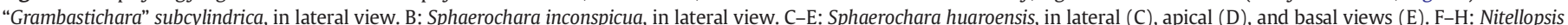

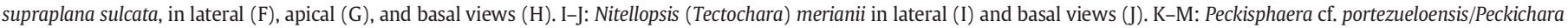
sp., in lateral (K), apical (L), and basal views (M). N: Peckichara cf. varians, in lateral view. Scale bars $=500 \mu \mathrm{m}$.

osteichthyans, crocodiles, rodents, and metatherians; Figs. O, AA-AB), although less species-rich (Supplementary Data). Only CTA-29 provides further information on xenarthrans, with an unidentified tolypeutine dasypodid and a cingulate (Fig. 6AB) showing close affinities with Eocoleophorus from the late Oligocene of Taubaté, Brazil and Salla, Bolivia; Salas-Gismondi et al., 2011) and Yuruatherium from the late Eocene-early Oligocene of Argentina and Peru (Ciancio et al., 2013).

Overall, the fossil assemblages recovered throughout the Lower Member of the Pozo Fm. in Contamana seem to document a single phase of Proto-Amazonian ecosystems, under stable conditions, by late middle Eocene times (Barrancan age; Antoine et al., 2012; Woodburne et al., 2014).

3.1.2.3. Age. As the upper Member of the Pozo Fm. seems not to crop out in the studied area, no age range can be ascertained for the complete formation. However, based on both mammalian biostratigraphy and palynostratigraphy (Antoine et al., 2012), and radioisotopy ( $\mathrm{Ar} / \mathrm{Ar}$ on feldspars in CTA-29; Fig. 5C; Antoine et al., 2012), the exposed unit is unambiguously assigned to the late middle Eocene (from CTA-48 up to CTA-29 [NE flank] and CTA-66 [SW flank]; Figs. 3; S1). The CTA-27 locality is estimated at $\sim 41 \mathrm{Ma}$ on the same ground (Antoine et al., 2012), coinciding with the early Bartonian stage (Vandenberghe et al., 2012) and the Barrancan age (Casamayoran SALMA; Woodburne et al., 2014). Depending on the species concerned, charophytes from the Lower Member of the Pozo Fm. (Table 2) span the Santonian-early Oligocene interval (e.g., Lychnothamnus (Pseudoharrisichara) tenuis and Lychnothamnus major, respectively; Musacchio, 2010; Sanjuan and Martín-Closas, 2012), with a strong Eocene signature (Raskyella pecki meridionale, Nodosochara jorbae, and Stephanochara acris; Martín-Closas and Guerrero, 2005; Adaci et al., 2007; Sanjuan and Martín-Closas, 2014). The ostracods further support an Eocene age for the fossiliferous part of the Pozo Fm. on the Contamana area, based on the co-occurrence of Neocyprideis apostolescui (middle-late Eocene; Mebrouk et al., 2009) and Ilyocypris aff. lusitanica (earliest Eocene affinities; Colin and Antunes, 2003).
Given the preserved thickness of the Lower Pozo Fm. above CTA-29 in the NE flank of the Maquía Anticline ( $300 \mathrm{~m})$, its top is likely to record the late Eocene interval.

3.1.2.4. Depositional environment. The exposed part of the Pozo Fm. (300-550 m-thick) consists only of thin lenses of reddish silt and yellowish sandstone, of fluvial origin, alternating with thick intervals of variegated paleosols and distal floodplain deposits (Fig. 5A). Some levels scattered throughout the exposed units show thick interwoven anhydrite veins, likely due to seasonal variation. The paleontological content (charophytes, pollen, and spores; decapods, mollusks, and ostracods; fish, crocodylomorphs, and mammals; Fig. 6) is mostly of continental affinities, either aquatic or terrestrial/arboreal (Antoine et al., 2012; Adnet et al., 2014). In the entire studied area, the only evidence for a marine influence during the concerned interval is the co-occurrence of dinoflagellates Cleistosphaeridium, Leiosphaeridia, and Spiniferites in the lowermost observable level (CTA-47; Table S3). This marine influence may coincide with what is reported on coeval deposits from the Huallaga area (marine and/or tide-influenced Pozo Fm.; Hermoza et al., 2005). Above in the Pozo Fm., a single ostracod recognized in CTA-27 (Neocyprideis apostolescui; Fig. 6G) may indicate euryhalinemesohaline conditions, but this taxon is known to tolerate salinity changes and is associated with a strictly freshwater fauna and flora with no evidence of marine influence (Antoine et al., 2012; Adnet et al., 2014).

In the Contamana area, the Upper Pozo Fm. was most probably eroded, and then unconformably overlain by deposits of the Chambira Fm. after differential vertical movements at local and/or regional scale. This hypothesis is supported by a strong discrepancy in the preserved thickness of the Pozo Fm. above the marker ash (Fig. S1), between the SW flank of the Maquía Anticline (Pozo/Chambira transition $~ 50 \mathrm{~m}$ above the ash at CTA-67) and its NE flank (Pozo/Chambira transition $\sim 300 \mathrm{~m}$ above the ash at CTA-29).

3.1.2.5. Correlation. These levels can be correlated with those of the Cruzeiro Formation in the upper Yuruá ("red beds" at the Peru/Brazil 
Table 2

Stratigraphic and temporal distribution of charophyte taxa recognized in the Paleogene of Contamana (Huchpayacu and Pozo Fms.), Peruvian Amazonia.

\begin{tabular}{|c|c|c|c|c|c|c|c|c|c|c|}
\hline \multirow[t]{2}{*}{ Taxon name } & \multicolumn{9}{|c|}{ Localities/number of specimens } & \multirow{2}{*}{$\begin{array}{l}\text { Stratigraphic range } \\
\text { (and references) }\end{array}$} \\
\hline & 崔 & 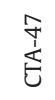 & 点 & $\stackrel{m}{\prod^{\prime}}$ & 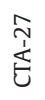 & $\begin{array}{l}0 \\
\vdots \\
\vdots \\
\vdots\end{array}$ & 온 & $\stackrel{+}{\stackrel{+}{+}}$ & 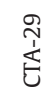 & \\
\hline $\begin{array}{l}\text { Chara "Grambastichara" } \\
\text { subcylindrica }\end{array}$ & 15 & & & & & & & & & $\begin{array}{l}\text { Paleocene-early Eocene; } \\
\text { Mourier et al. (1988) }\end{array}$ \\
\hline Sphaerochara inconspicua & 13 & & & & & & & & & $\begin{array}{l}\text { Cretaceous-Paleocene; } \\
\text { Feist \& Brouwers, (1990) }\end{array}$ \\
\hline Sphaerochara huaroensis & 19 & & & & & & & & & $\begin{array}{c}\text { early Paleocene; } \\
\text { Jaillard et al. (1994) }\end{array}$ \\
\hline Nitellopsis supraplana sulcata & 12 & & & & & & & & & $\begin{array}{c}\text { Paleocene-early Eocene; } \\
\text { Mourier et al. (1988) }\end{array}$ \\
\hline $\begin{array}{l}\text { Peckisphaera cf. portezueloensis } \\
\text { - Peckichara sp. }\end{array}$ & 11 & & & & & & & & & $\begin{array}{l}\text { latest Cretaceous; Chassagne- } \\
\text { Chassagne-Manoukian et al. } \\
\text { (2013) }\end{array}$ \\
\hline Pseudolatochara sp. & 16 & & & & & & & & & $\begin{array}{l}\text { Cretaceous-Eocene; } \\
\text { Vialle et al. (2013) }\end{array}$ \\
\hline Nitellopsis (Tectochara) merianii & 14 & & & & & & & & & panchronic \\
\hline Peckichara cf. varians & 2 & & & & & & & & & $\begin{array}{c}\text { Paleocene; } \\
\text { Musacchio, (2006) }\end{array}$ \\
\hline Chara? sp. & 20 & & & & & & & & & panchronic \\
\hline Lamprothamnium sp.? & 20 & & & & & & & & & $\begin{array}{c}\text { Paleocene; } \\
\text { Musacchio, (2006) }\end{array}$ \\
\hline Brevichara sp.? & 4 & & & & & & & & & panchronic \\
\hline Platychara cf. perlata? & 5 & & & & & & & & & $\begin{array}{c}\text { late Cretaceous-early } \\
\text { Paleocene; Louterbach et al. } \\
\text { (2014) }\end{array}$ \\
\hline Peckichara sp.? & 3 & & & & & & & & & $\begin{array}{c}\text { late Cretaceous-Paleocene; } \\
\text { Mebrouk et al. (2009) }\end{array}$ \\
\hline Charales indet. & 30 & 4 & & & & & & & & panchronic \\
\hline Raskyella pecki meridionale & & 5 & 4 & & 3 & 2 & 30 & 41 & 15 & $\begin{array}{c}\text { Eocene; Martín-Closas \& } \\
\text { Guerrero, (2005) }\end{array}$ \\
\hline Nodosochara jorbae & & 4 & & & & & & & & $\begin{array}{c}\text { Eocene; } \\
\text { Adaci et al. (2007); Sanjuan \& } \\
\text { Martín-Closas, (2014) }\end{array}$ \\
\hline $\begin{array}{l}\text { Pseudolatochara sp.? - } \\
\text { Latochara sp.? }\end{array}$ & & 3 & & & & & & & & $\begin{array}{l}\text { Paleocene-Eocene; } \\
\text { Vialle el al. (2013) }\end{array}$ \\
\hline Lamprothamnium stipitatum & & & 6 & & & & & & & panchronic \\
\hline Nitellopsis (Tectochara) latispira & & & & 2 & & & & & & $\begin{array}{l}\text { late Eocene-early Oligocene; } \\
\text { Sanjuan \& Martín-Closas, } \\
\text { (2014) }\end{array}$ \\
\hline Chara (Grambastichara) tornata & & & & 10 & & & & & & panchronic \\
\hline Psilochara sp. & & & & 6 & & 2 & & & & panchronic \\
\hline Stephanochara acris & & & & & 4 & & & & & $\begin{array}{c}\text { Ypresian; } \\
\text { Adaci et al. (2007) }\end{array}$ \\
\hline Lychnothamnus major & & & & & & 1 & & & & $\begin{array}{c}\text { early Oligocene; San Juan \& } \\
\text { Martín-Closas, (2014) }\end{array}$ \\
\hline $\begin{array}{l}\text { Lychnothamnus } \\
\text { (Pseudoharrisichara) tenuis }\end{array}$ & & & & & & 1 & & & & $\begin{array}{c}\text { Santonian-Campanian; } \\
\text { Musacchio, (2010) }\end{array}$ \\
\hline Lychnothamnus sp.? & & & & & & 2 & 4 & & & panchronic \\
\hline Total number of specimens & 184 & 16 & 10 & 18 & 7 & 6 & 34 & 41 & 15 & \\
\hline
\end{tabular}

border; Oppenheim, 1937). The inferred time span also coincides with that documented by the NPFB for the Pozo Fm using low-temperature thermochronology (Hermoza et al., 2005; Roddaz et al., 2010). Although documenting somewhat distinct depositional environments (freshwater-dominated in the Ucayali basin; marine/tidal-dominated in the Huallaga basin), both units are laterally equivalent. 'Pozo Sands' in the Huallaga and Marañon basins (NPFB) are considered laterally equivalent to the Upper Tiyuyacu Fm. in the Oriente Basin of Ecuador, which is capping a important erosional unconformity with strong geodynamic significance (Christophoul et al., 2002). This interval is not unambiguously documented in the SPFB (see Louterbach et al., 2014 for a review).

\subsubsection{Chambira Formation (Oligocene-?early Miocene)}

3.1.3.1. Description (Fig. 7). In the Contamana area, coarser deposits of the Chambira Fm. overlay unconformably the variegated paleosols and silts of the Lower Pozo Fm.

On both flanks of the Maquía Anticline, the Chambira Fm. mainly consists of thick compounds of red paleosols, with intercalated conglomerates and sandbars (with trough and planar cross-stratifications; CTA-74) at the base. The base of the Chambira Fm. is defined by the lowermost channelized conglomerates showing both sharp quartz pebbles and multicolor volcanic/metamorphic clasts and a sandy matrix (CTA- 

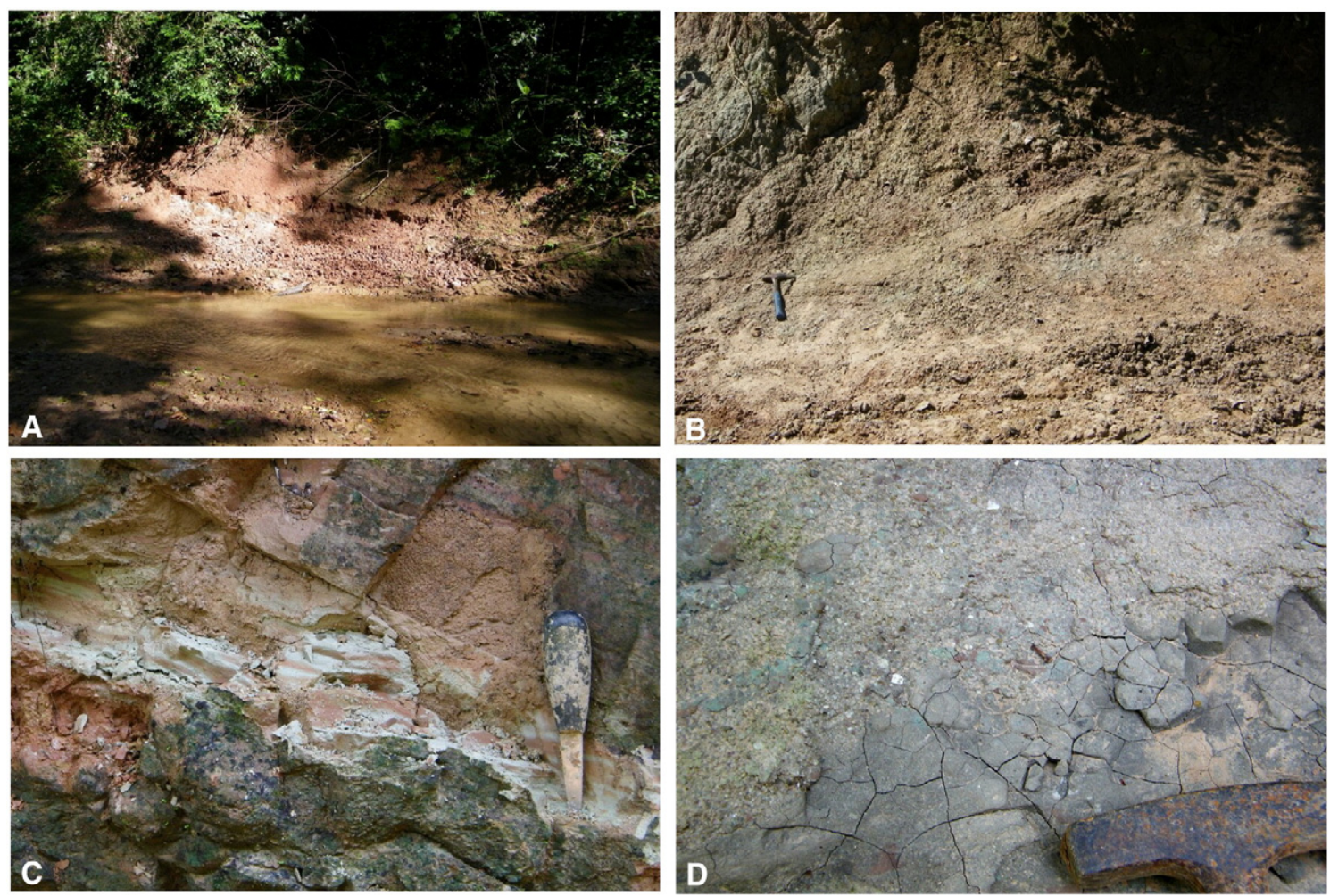

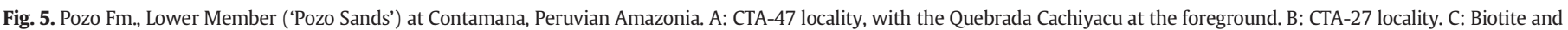
feldspar-yielding tuff dated $43.44 \pm 2.5 \mathrm{Ma}$ at CTA-29. D: Carbonated nodule-rich sandy clays at CTA-66.

62; Figs. 2-3; S1). Another conglomerate with similar characteristics (CTA-61; Fig. 7C) occurs $15 \mathrm{~m}$ above the latter level in the SW flank, further attesting to a drastic change in the regional sedimentary dynamics. On the NE flank of the Maquía Anticline, a $50 \mathrm{~cm}$-thick and $10 \mathrm{~m}$-wide fluvio-lacustrine channel (CTA-32; Figs. 2-3) is located $\sim 30 \mathrm{~m}$ above the basal conglomerate (Fig. S1). This lens consists of a $15 \mathrm{~cm}$-thick conglomerate with centimetric pebbles of fluvial origin, topped by bluish lacustrine clays, which have yielded an abundant and species-rich vertebrate fauna (CTA-32; Fig. 7A-B; see Supplementary Data).

The middle and upper parts of the Chambira Fm. provided no fossil record except for a tree stump of an unidentified dicot (CTA-78; Figs. 2, 7D). These deposits primarily consist of red paleosols intersected locally by anhydrite veins, with rare intercalated sandbars. A remote and species-poor vertebrate locality, situated on the road to Agua Caliente (CTA-72; Fig. 1B; Supplementary Data), is correlated to an unidentified term of the Chambira Fm., based on both its extrapolated stratigraphical position and compatible facies (red paleosol with anhydrite veins).

The total thickness of the Chambira Fm. is $180 \mathrm{~m}$ in the SW flank of the Maquía Anticline (Figs. 3, S1). In the NE flank, the transition seems to be gradational with the Pebas Fm. and we have not recognized any unquestionable level referable to the latter in the Cachiyacu syncline. It is impossible to estimate properly any thickness for the Chambira Fm. in the Agua Caliente section.

3.1.3.2. Paleontological content (Fig. 8). The Chambira Fm. in the Contamana region encompasses only five fossil-yielding localities, widely dominated by vertebrates, in three distinct areas: three successive levels are recorded in the SW flank of the Maquía Anticline (from the base to the top, CTA-62, CTA-61, and CTA-74; Fig. 2); a single locality, interpreted as documenting both a sub-coeval interval and distinct environmental conditions, was uncovered in the NE flank of the Maquía Anticline (CTA-32; Figs. 2, 7A-B, S1); the last one, CTA-72, was found in 2014 on the road to Agua Caliente. Its fossil content is of poor taxonomic and stratigraphical interest (Figs. 1-2; Supplementary Data). There is no palynological record for the entire Chambira Fm. in the Contamana area. Two fossiliferous localities are especially species-rich (CTA-32 and CTA-61).

CTA-32 yielded fossil wood, crabs, and 43 vertebrate species (Fig. 8AF, N-R; Supplementary Data). This assemblage includes potamotrygonid freshwater stingrays, a wide array of osteichthyans (serrasalmine, anostomid, cynodontid, erythrinid, and characid characiforms (Fig. 8A); pimelodid and loricariid siluriforms; a perciform), anurans (at least one non-pipid), snakes (two booids and two non-booids, including a possible colubroid), chelonians, four crocodylomorphs (a sebecid, two caimanines, and a gavialoid), a bird, plus 24 mammalian taxa. Five metatherians are recognized: a stem metatherian (?herpetotheriid), a ?palaeothentid and two abderitid paucituberculatans (Abderites sp. and cf. Abderites; Fig. 8D-E), and a microbiotheriid. Placentals are represented by scutes referable to cingulate xenarthrans (cf. Neoglyptatelus, of uncertain affinities; a pampatheriid (Fig. 8F), close to Yuruatherium from Santa Rosa, Peru as described by Ciancio et al. (2013); a tolypeutine dasypodid), tooth fragments of native ungulates (hypsodont notoungulate, ?litoptern, and astrapotheriid astrapothere), teeth of six distinct rodents (two caviomorphs of uncertain affinities, a small erethizontid, and three octodontoids including an adelphomyine and cf. Eosallamys sp.; Fig. 8N), teeth of three microchiropterans (an emballonurid [Fig. 80], an vespertilionoid, and a ?rhinolophoid), and a pollical phalanx of an anthropoid primate (Fig. 8P-R).

The fossil assemblage of CTA-61 (Fig. 8G-M) encompasses exclusively 39 vertebrate taxa, with amphibian, snake, crocodylomorph, and chelonian components highly similar with those of CTA-32 (Supplementary Data). Yet, fish faunas widely differ between the two sites, especially as regards characiforms (a piranha-like characid, an erythrinid, a characid, and an unidentified characiform with hook-like teeth only occur in CTA-32; CTA-61 yields two unidentified characiforms with domed and tricuspid teeth, respectively), but also siluriforms (a small pimelodid and a loricariid are recognized in CTA32; a large Phractocephalus-like pimelodid siluriform is recorded only in CTA-61) and perciforms (an unidentified cichlid occurs in CTA-32). Twenty-one mammalian species are recognized in CTA-61. The fauna 

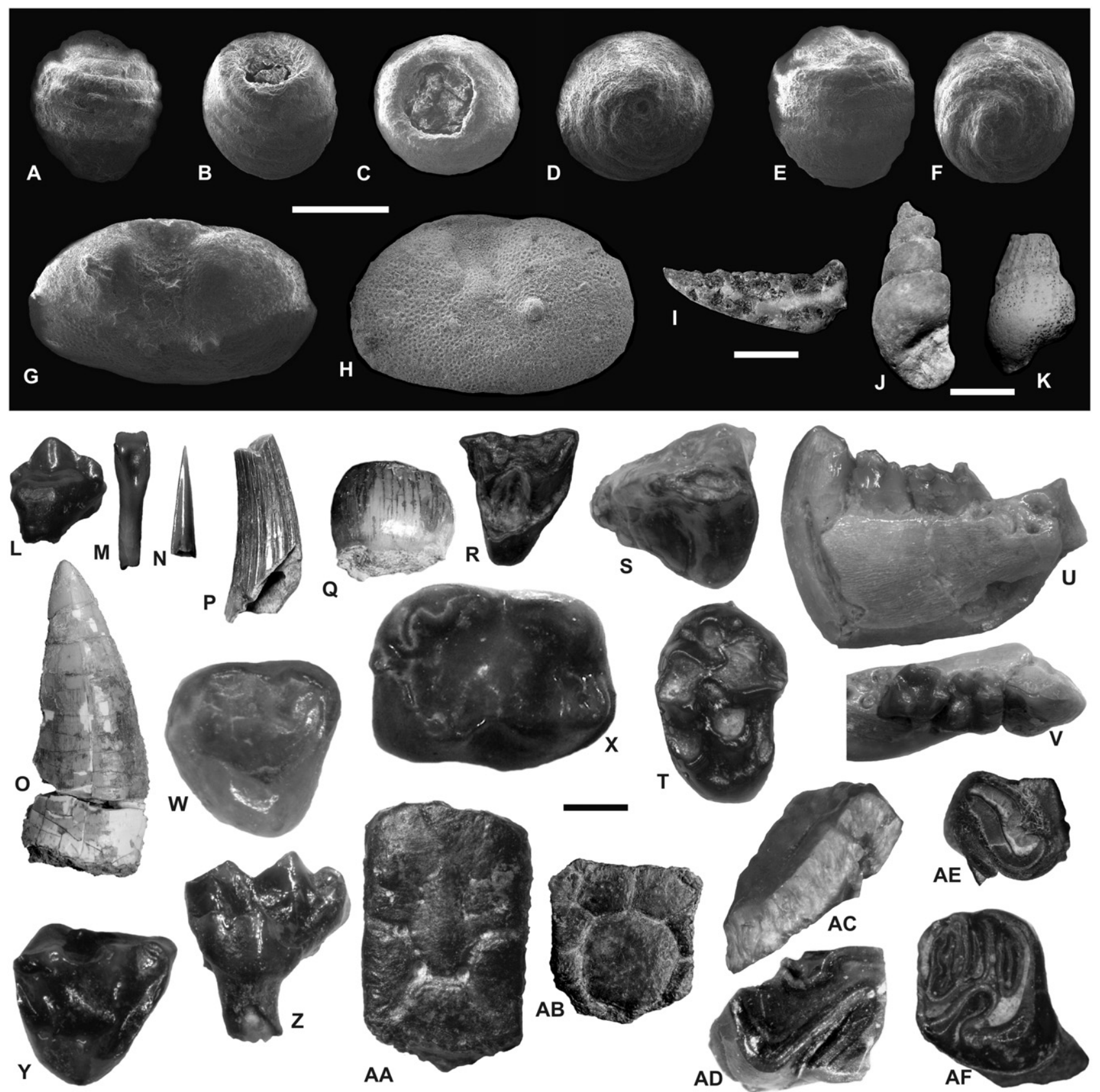
cavioid (Supplementary Data). The rodent assemblage notably includes cf. Eoincamys sp. (Fig. 8L), Eoespina? sp. and Deseadomys sp. (Fig. 8M; not Ethelomys sensu Vucetich et al., 2015). A primate has been recognized in CTA-61, provisionally identified as a soriacebine homunculid, and another one, of uncertain affinities, at CTA-32. Faunal differences between CTA-32 and CTA-61 may primarily be due to distinct ecological conditions and/or depositional environments (high-energy stream in CTA-61 vs. pond in CTA-32, with contrasted grain sizes resulting in systematic fossil biases), rather than a significant temporal gap between the two sites.

Such discrepancies between CTA-32 and CTA-61 may coincide at first order with highly distinct conditions in terms of ecology and depositional environments (high-energy stream vs. steady pond in CTA-61 and CTA-32, respectively, with contrasted grain sizes engendering a systematic bias for fossil specimens), instead of documenting a significant stratigraphical gap between CTA-32 and CTA-61.

Contrary to what was observed in most fossil-yielding levels of the Pozo Fm., neither charophyte oogonia nor ostracods were recovered in the Chambira Fm. in the studied area (Table 2). Furthermore, in contrast to the fossil content of both the Pozo Fm. (below) and the Pebas Fm. (above), Chambira thanatocenoses are widely dominated by their vertebrate component in the Contamana area (no mollusk is recorded either through inner casts or shells). As regards plant fossils, only a tree stump of undetermined affinities (within dicotyledons) was recovered in the uppermost term of the Chambira Fm. (CTA-78; Fig. 7D).

3.1.3.3. Age. A $30 \mathrm{~cm}$-thick tuffaceous bed (CTA-08SA) was recognized in the lowermost part of the Chambira Fm. in the SW flank of the Maquía Anticline (Figs. 2-3). We have not recovered any lateral equivalent of this bed in the NE flank. This level was dated by $\mathrm{U} / \mathrm{Pb}$ on zircon grains giving an inferred age of $26.56 \pm 0.07 \mathrm{Ma}$, which coincides with the late Oligocene Chattian stage, and the Deseadan SALMA (Vandenberghe et al., 2012) [See Supplementary Data]. Given the local dipping, the CTA-61 locality is situated $\sim 4 \mathrm{~m}$ above this tuffaceous bed and thus is no older than about 26.5-26.4 Ma.
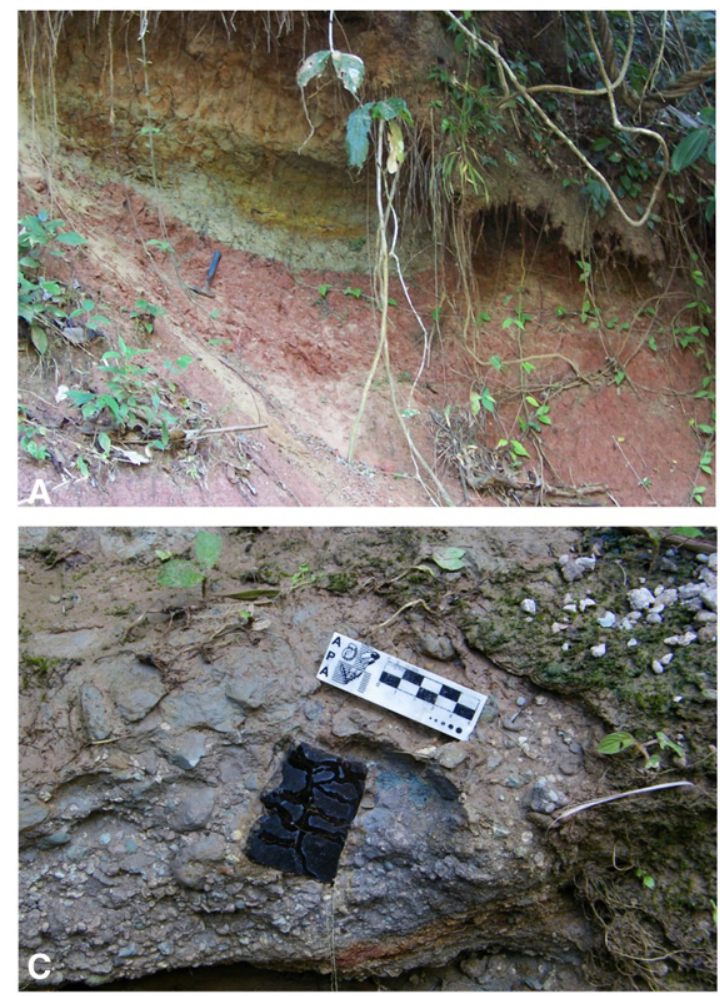

The mammal fossil record of the late Oligocene is mostly documented in Argentina, Bolivia (Salla), Brazil (Taubaté), Uruguay (Fray Bentos; Bond et al., 1998), and SW Peru (Moquegua; Shockey et al., 2006; Croft et al., 2009; Shockey et al., 2009), as synthesized by Woodburne et al. (2014) and Vucetich et al. (2015). Vertebrates from the Chambira Fm. (Supplementary Data) encompass typical Deseadan taxa (abderitid marsupials, an archaeohyracid or basal hegetotheriid, and the octodontoid Deseadomys; Vucetich et al., 2015), as well as taxa of either earlier (the rodents cf. Eoincamys sp., Eoespina sp., and cf. Eosallamys sp. [Santa Rosa; Frailey and Campbell, 2004]) or later affinities (a caenolestid, Abderites, the caimanine cf. Purussaurus, or the cingulate cf. Neoglyptatelus).

In the Contamana area, most available proxies (ash CTA-08SA and fossil assemblages CTA-32 and CTA-61) consistently point to a late Oligocene age for the base of the Chambira Fm (Supplementary Data). The concerned conglomerate further attests to a drastic change in the regional sedimentary dynamics, and its deposition probably coincided with the onset of a major exhumation phase in the eastern Cordillera of the Central Andes during the late Oligocene (Mora et al., 2010; Eude et al., 2015). Unfortunately, we could not find any chrono- or biostratigraphic data higher up in that formation. Yet, the level that we interpret as documenting the base of the overlying Pebas Fm. is early Miocene in age ( 20-17 Ma; Colhuehuapian-Santacrucian SALMAs; see hereafter). In other words, as the Pebas Fm. conformably overlies it, the Chambira Fm. most likely spans the late Oligocene-earliest Miocene interval in the Contamana area.

3.1.3.4. Depositional environment. Three main depositional environments are recognized for the Chambira Fm. The conglomerates and sandbars observed in the lower term on the SW flank of the Maquía Anticline indicate the occurrence of channelized fluvial settings (Fig. 7C). The gray-blue clays topping the conglomeratic channel (CTA-32) in the NE flank would point to the coeval occurrence of a steady water pond (which is further supported by the crocodile and fish fauna; Fig. 7A-B; Supplementary Data). The blue clays of CTA-32 yield neither
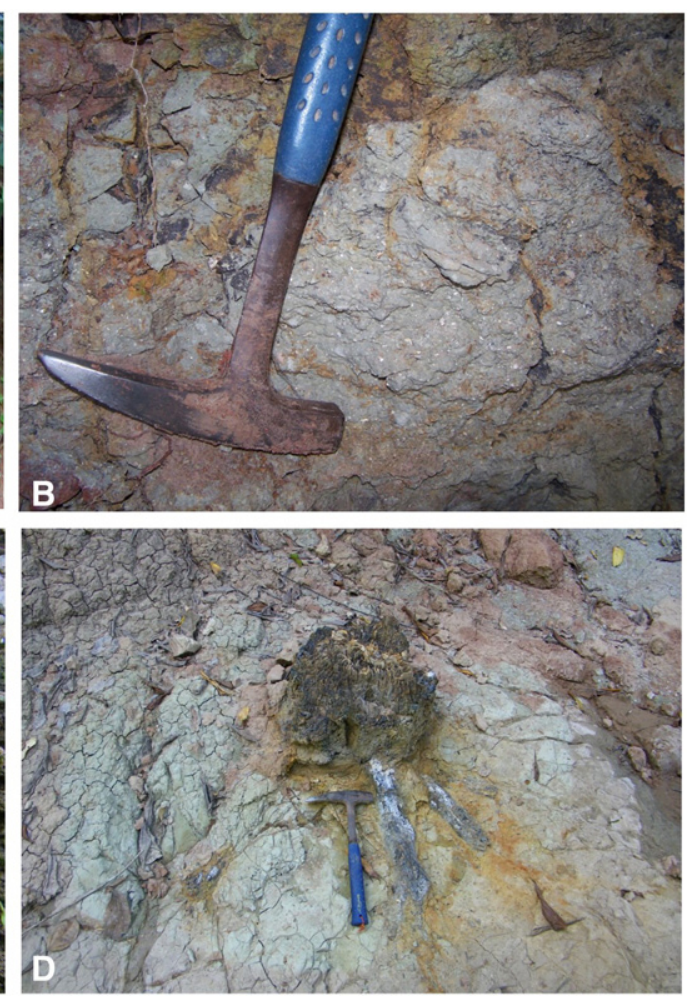

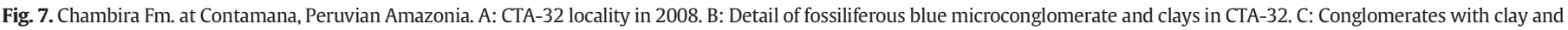

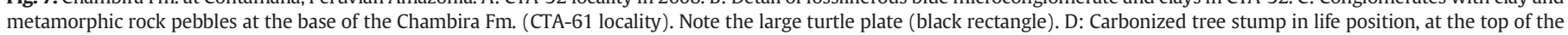
Chambira Fm. (CTA-78) 
carbonized/lignitous wood nor pyrite nodules (contrary to what is observed throughout the Pebas Fm.). These channels are intercalated with distal floodplain deposits and paleosols, implying the preponderance of terra firme in the area, which is in turn consistent with the paleontological content as recorded in the concerned deposits (see above) and the presence of a fossil tree stump, found in-situ at the top of the Chambira Fm. (CTA-78; Figs. 3, 7D, S1). No marine influence is recorded throughout the Chambira Fm. in the Contamana area, either based on sedimentology, ichnology, or paleontology (Supplementary Data; Table S3).

3.1.3.5. Correlation. The Chambira Fm. is also recognized in the NPFB and SPFB (e.g., Roddaz et al., 2010). Based on observations in the NPFB, Marocco et al. (1996) proposed that the deposits of the Chambira Fm. were ranging from the late Oligocene up to the middle Miocene, in fairly good agreement with our own observations.

\subsubsection{Pebas Formation (late early to early late Miocene interval)}

3.1.4.1. Description (Fig. 9). The Pebas Fm. is here for the first time recognized formally in the Ucayali Basin area, based on both sedimentological and paleontological arguments. Unambiguous Pebasian deposits crop out only in the SE flank of the Maquía Anticline and on the road to Agua Caliente (CTA-77; Figs. 1-2). The lowermost outcrop assigned to that formation (CTA-63; Figs. 2-3) consists of a 5 m-thick sequence with blue silts showing herringbone cross-bedding, covered by laminated blue clays with millimetric leaf litters and topped by a $2 \mathrm{~m}$-thick blue clay, with pyrite nodules, lignitous wood and litter, and a rich vertebrate fauna. The Pebas sequence mainly comprises blue floodplain siltites and red paleosols, with scattered intercalated conglomeratic channels, rich in lignitous and/or pyritized floated wood (e.g. CTA-45, CTA-44, CTA43, CTA-10, or CTA-75; Fig. 9). The corresponding section is coarsening upward (Fig. 3). In the SE flank of the Maquía Anticline, deposits of the Pebas Fm. crop out continuously between CTA-63 and CTA-75 (Fig. 2), with a measured thickness of $340 \mathrm{~m}$ (Figs. 3, S1), in good agreement with the "maximum thickness of $\sim 500$ m" proposed by Roddaz et al. (2010). Some carbonated levels crop out throughout the sequence (decimetric limestone nodules in CTA-45; mollusk-rich hardground in CTA-44 Base [Fig. 9B]; calcretes of diagenetic origin in CTA-75). The uppermost level is CTA-75 (Fig. 3), a sandy polygenic conglomeratic channel with a species-poor vertebrate and mollusk assemblage (Supplementary Data), topped by a calcrete-rich paleosol.

A $1 \mathrm{~m}$-thick seismite, with sismoslumps, crops out in the upper part of the Pebas Fm. ( $40 \mathrm{~m}$ above CTA-43 and $5 \mathrm{~m}$ below CTA-76), intercalated between low-energy whitish sandstones with trough crossstratification.

3.1.4.2. Paleontological content (Fig. 10). In contrast to the underlying sediments of the Huchpayacu, Pozo, and Chambira formations, the fossil record of Pebasian deposits is much better documented at the Western Amazonian scale (e.g., Hoorn and Wesselingh, 2010; Salas-Gismondi et al., 2015). The Contamana area is no exception, with many diversified assemblages recovered, encompassing plant remains (essentially pollen and spores, but also floated wood, carbonized fruits and seeds), foraminifers, dinoflagellates, mollusks (inner moulds or shells preserved), crustaceans (ostracods and crabs), annelids and poriferans (CTA-58 and CTA-77), urchins (CTA-58), and species-rich vertebrate faunas (>30 taxa in CTA-63, CTA-44 Top, and CTA-43; Supplementary Data).

The pollen and spore record is excellent, especially in CTA-44 Middle (130 taxa identified; see Table S3). The most characteristic palynological associations in the fluvial settings contained a wide variety of rainforest taxa including families Arecaceae, Melastomataceae, Sapotaceae, Euphorbiaceae, Leguminosae, Annonaceae, Meliaceae, Malvaceae and Malpighiaceae (Table S3). The most abundant taxa were those nearest to the aquatic depositional environment such as Mauritia (Mauritiidites), typical of palm swamps, accompanied by taxa from the

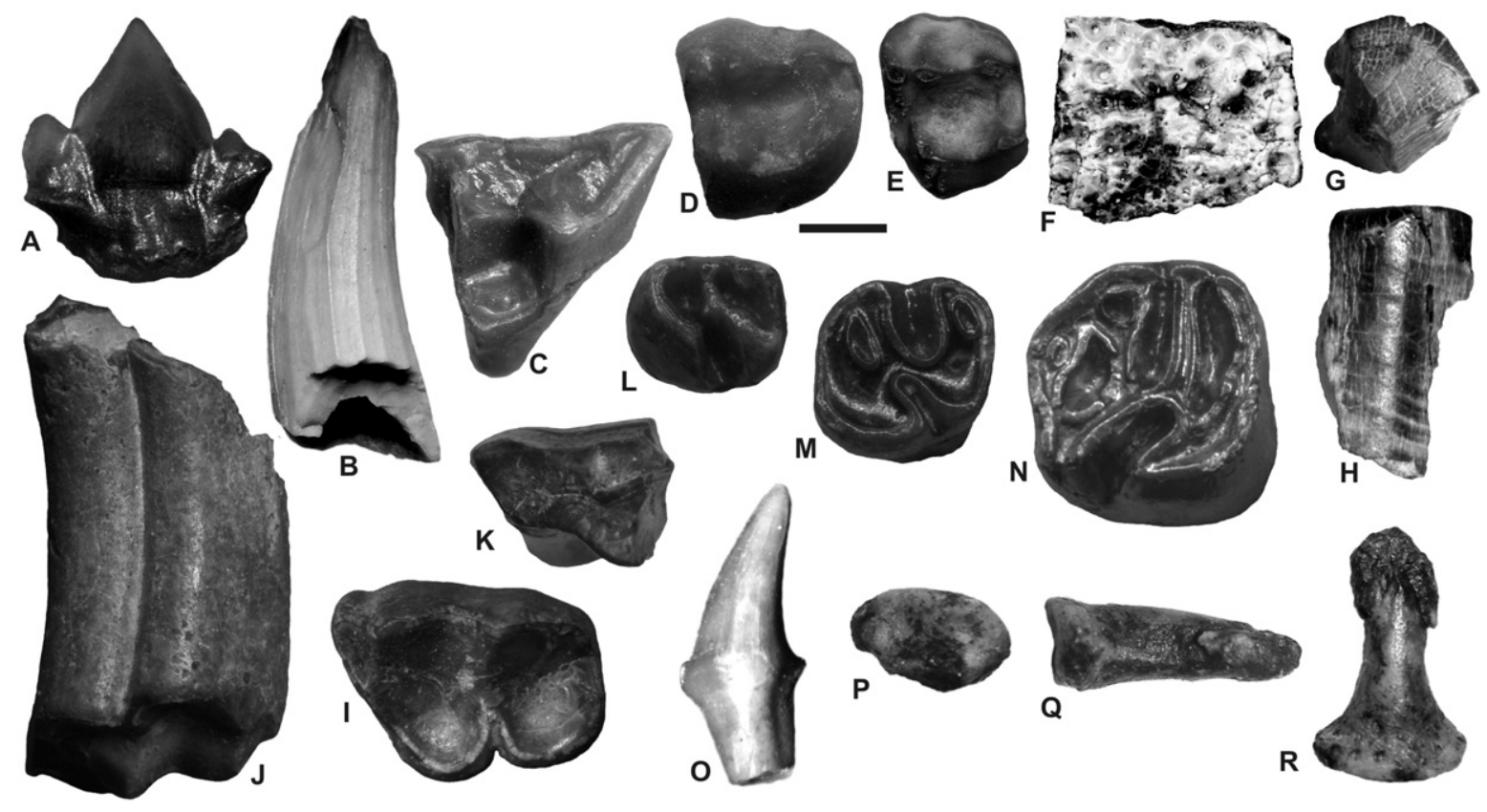

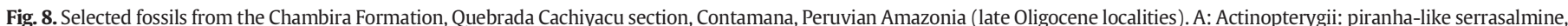

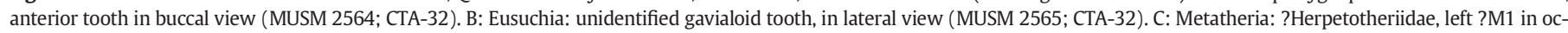

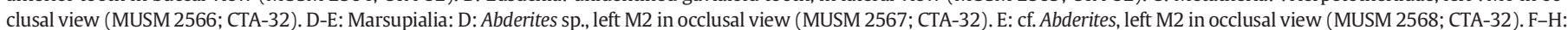

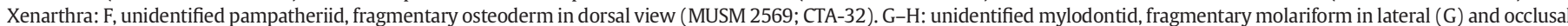

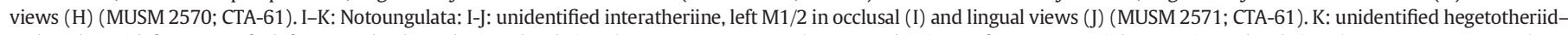

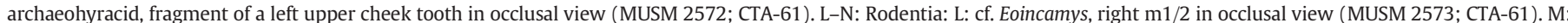

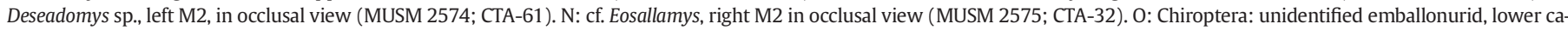

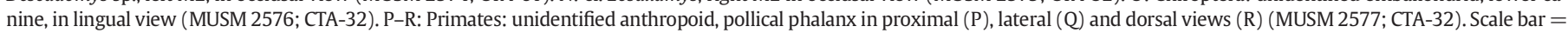
$1 \mathrm{~mm}$ (A, C-E, L-R), $2 \mathrm{~mm}$ (B, I-K), and $5 \mathrm{~mm}(\mathrm{~F}-\mathrm{H})$. 
fluvial overbanks such as Amanoa (Retitrescolpites? irregularis), Alchornea (Ranunculacidites operculatus), and Malvaceae (including several Bombacoideae). The presence of aquatic (mostly freshwater) settings is supported by taxa such as the fern Ceratopteris (Magnastriatites grandiosus), a small aquatic fern bordering lakes and riverbanks (Germeraad et al., 1968) and freshwater algae Botryococcus and Azolla. These fluvial/freshwater settings were occasionally disrupted by marine floodings, as suggested by sample CTA-44 Middle that has a moderate abundance of marine palynomorphs, including at least four species of dinoflagellate cysts (referred to as the genera Spiniferites, Brigantedinium, Impletosphaeridium, and Trinovantenidium), and chitinous foraminiferal test linings (Table S3), with a preservation similar to that from other Pebasian localities from Western Amazonia (see Boonstra et al., 2015). Spiniferites sp. was also recovered from CTA-58.

Microfossils were recovered in three localities (CTA-44 Middle, CTA-58, and CTA-77), all considered to be laterally equivalent and coinciding with the middle-late Miocene transition, based on both lithostratigraphical and paleontological proxies. Foraminiferan assemblages (poorly diversified: 4-21 co-occurring species; Fig. 10A-G) are dominated by Ammonia beccarii (up to $80 \%$ in terms of specimens; Fig. 10A) and widely homotaxic at the species level, especially between CTA-58 and CTA-77 (Simpson Index $=100$ ) or CTA-44 and CTA-77 (Simpson Index $=50$ ), to a lesser extent between CTA-44 and CTA-58 (Simpson Index $=25$; Supplementary Data). Ostracod assemblages are dominated by Cytheroidea (with both cosmopolitan and endemic taxa; Fig. 10H-I). Calcareous algae and dinoflagellates are also characteristic for these levels. Foraminifers are strikingly reminiscent of those from Colombian Amazonia (e.g., Leticia, Puerto Nariño, Zaragoza and Macarena), whereas ostracods are mainly "Pebasian" (sensu Wesselingh et al., 2006).

Inframillimetric burrows and calcium carbonate tubes on oyster shells recovered in CTA-58 and CTA-77 attest to the presence of clionid demosponges and serpulid annelids, respectively.

Mollusks recovered from the Cachiyacu section are typical Pebasian endemics (sensu Wesselingh et al., 2006; Fig. 10R-T; Supplementary Data). Their alpha-diversity is low with respect to what is recorded at the Pebas Mega-Wetland scale (1-13 associated species in CTA-44 Base vs. up to 95 co-occurring species in late middle Miocene localities around the city of Iquitos; Wesselingh et al., 2006, chap. 2). On the other hand, ostreid bivalves (Crassostrea sp., thousands of specimens found in-situ, with associated valves, in CTA-58 and CTA-77) are attested for the first time in Western Amazonia (Figs. 9D, 10R-S).

Crustaceans are documented by decapods (trichodactylid crabs, found only in the middle and upper members; Table S2) and Pebasian ostracod assemblages (CTA-58 and CTA-77, moderately diversified; Supplementary Data), the latter mostly consisting of representatives of the Cyprideis species flock (Fig. 10H-I; Wesselingh and Ramos, 2010; Gross et al., 2013). These ostracod faunas are remarkably similar to that of a middle Miocene core nearby the Rio Iutí, in Western Brazil, which also yielded bryozoans and barnacles (Linhares et al., 2011).

Urchin spines were found associated with foraminiferans and dinoflagellates in CTA-58.

Vertebrates recovered from the Pebas Fm. in the Contamana area include selachians (stingrays, eagle rays, and sawfishes) and ray-finned fishes (mostly characiforms and siluriforms), but also a lepidosirenid lungfish (CTA-44 Top), sauropsids (snakes, lizards, crocodylomorphs, and turtles) and mammals.

Ichthyofauna is a conspicuous element of vertebrate assemblages in the concerned localities, with 10 to 13 co-occurring species (CTA-63, CTA-44 Top, CTA-43, and CTA-75; Supplementary Data). Most levels yield chondrichthyans (Fig. 10U-W), with a maximum diversity in CTA-44 Top (two potamotrygonids, a dasyatid, and a pristid) and CTA-43 (same association, plus a myliobatid; Supplementary Data). Actinopterygian faunas, strongly similar throughout the Pebas Fm. are dominated by large serrasalmine, cynodontid, and anostomid characiforms (pacus, piranhas, dogtooth characins, and headstanders, respectively) and, to a lesser extent, by small loricariid siluriforms (muffel-like teeth; Fig. 10X).

Pleurodirous chelonians are abundantly represented in terms of remains ( shell fragments). They mostly consist of podocnemidid turtles (Table S2), but several keeled plates are likely to attest to the presence of chelids in CTA-63.

Squamate remains are either referable to snakes of uncertain affinities (vertebrae: CTA-43, CTA-75) or a durophagous lizard (teiid/ tupinambid isolated tooth; CTA-63; Supplementary Data).

Crocodylomorph assemblages include up to four taxa, typically encompassing a gavialoid and one or two caimanines (Caiman, Purussaurus, and/or a durophagous species), but also a terrestrial sebecid (Langstonia sp.) in CTA-63 (Fig. 10K; Table S2). Such a composition is intermediate between what is observed in other Pebasian crocodylomorph hotspots such as the Fitzcarrald local fauna (SalasGismondi et al., 2007) and IQ-26/IQ-114 (nearby Iquitos, Peru; SalasGismondi et al., 2015).

Seven successive levels referred to the Pebas Fm. have yielded mammalian remains, and three of them are species-rich (12-16 co-occurring species in CTA-63, CTA-44 Top, and CTA-43; Supplementary Data). As usual in Miocene deposits from Western Amazonia (see Tejada-Lara et al., 2015), metatherian remains are rare and document a low taxonomic diversity (isolated teeth). They are represented by unidentified didelphimorphs (in CTA-63 and CTA-43; Fig. 10L), a marmosid didelphimorphian in CTA-43), a small sparassodont (CTA-44 Top), and an argyrolagid polydolopimorphian (CTA-43; Fig. 10Y-Z). Xenarthran specimens encompass cingulates, with Parapropalaeohoplophorus sp. in CTA-63 (Fig. 10M) and Neoglyptatelus sp. in CTA-43 (Fig. 10AA), pampatheriids (unidentified in CTA-63; cf. Scirrotherium sp. in CTA-44 Top and CTA-43; Fig. 10AB) and dasypodids (dasypodine in CTA-63; tolypeutine in CTA-44 Top; unidentified in CTA-43 and CTA-75) and a very few pilosan remains (Supplementary Data). Ground sloths, closely allied to Pseudoprepotherium and Octodontobradys from the middle Miocene of Colombia and late Miocene of Brazil (dos Santos et al., 1993), occur in CTA-63 and CTA-57, respectively (isolated teeth eight-shaped in occlusal view, and a claw; Fig. 10AC-AD). A second phalanx of a small mylodontoid sloth was also unearthed in CTA-43.

Remains documenting native South American ungulates are rare, with only a distal tibia and a lower molar fragment assigned to litopterns (CTA-75) and a few isolated notoungulate teeth collected, either protohypsodont (?leontinid toxodont in CTA-63), or hypselodont (toxodontid in CTA-63 and CTA-44 Top; interatheriine interatheriid in CTA-57; Fig. 10AE). No indisputable astrapotheriid remains were found in-situ.

In contrast, rodents are the most abundant and diversified mammalian component (mostly isolated teeth) of vertebrate assemblages in the deposits of the Pebas Fm. (Fig. 100Q AF-AL). The concerned remains document all major groups, such as Octodontoidea and Chinchilloidea (from CTA-63 up to CTA-75), but also Cavioidea, and Erethizontoidea. Octodontoids encompass Protadelphomys sp. (CTA-63; Fig. 100), a late representative of Acarechimys (CTA-43 and CTA-75; Fig. 10AF), and several taxa of unidentified affinities (Supplementary Data). Chinchilloids are more diversified among rodents (Fig. 10P-Q, AH-AL), with seven taxa occurring throughout the Pebas Fm. (CTA-63 / CTA-75), including Dinomyidae (e.g., low-crowned "Scleromys" in CTA-63; Potamarchus sp. in CTA-44 Top, CTA-43, and CTA-75; Drytomomys sp. in CTA-44 Top; eumegamyine in CTA-43; Simplimus? in CTA-57), and the neoepiblemid Neoepiblema sp. (CTA-44 Top and CTA-10). On the other hand, cavioids and erethizontoids are only observed in the upper part of the formation, with an unidentified dasyproctid (CTA-44 Top) and a new caviine (CTA-44 Top and CTA-43; Fig. 10AG), and the erethizontid Steiromys? sp. (CTA-43), respectively.

Bats are documented by an emballonurid in CTA-63 and CTA-75 (Fig. 10AM) and a molossid in CTA-44 Top (Supplementary Data). Isolated teeth of two new cebid primates (a medium-sized cebine and a tiny callithrichine) were recovered at CTA-43. No North American 

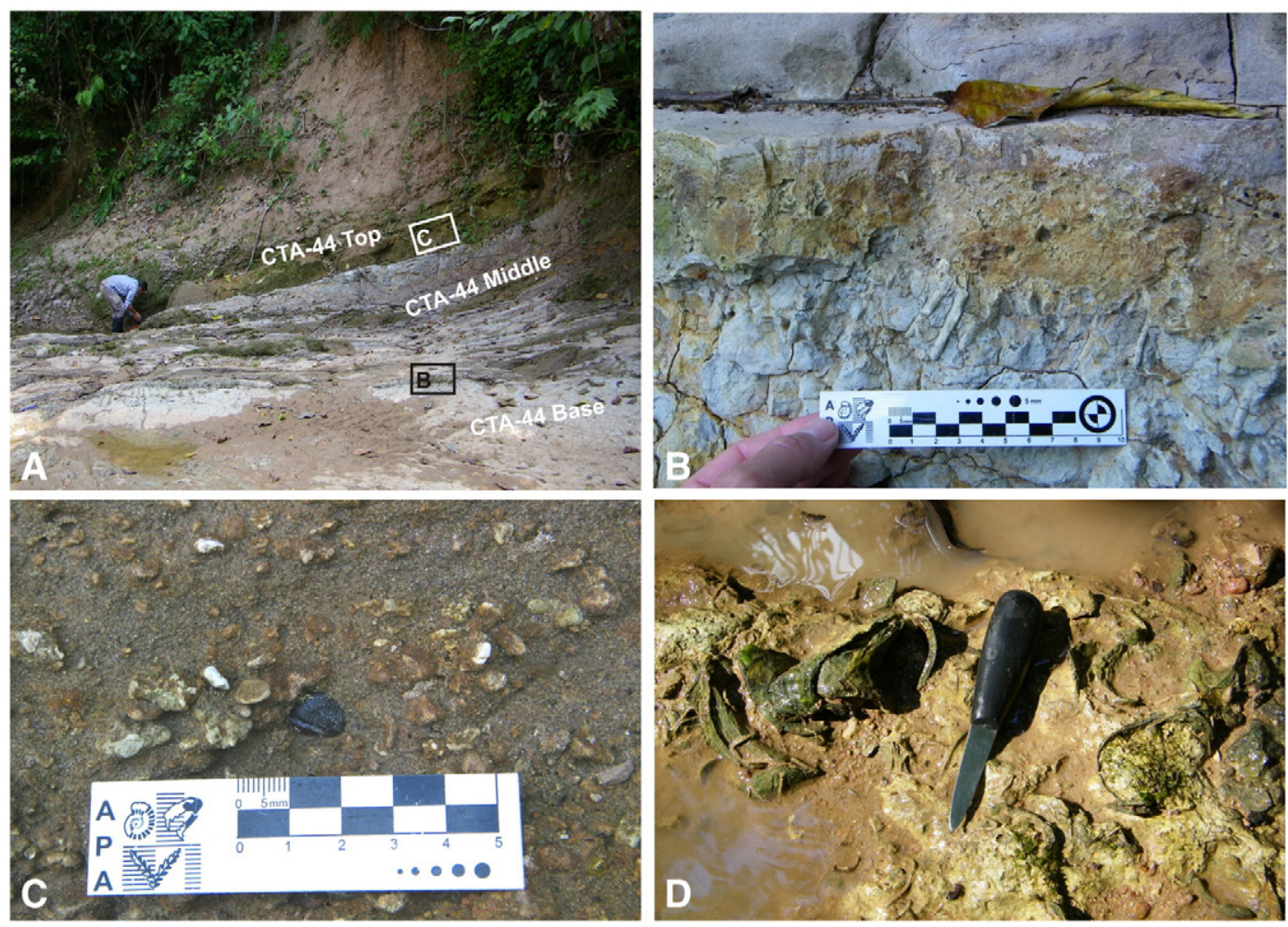

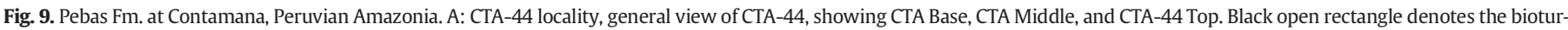

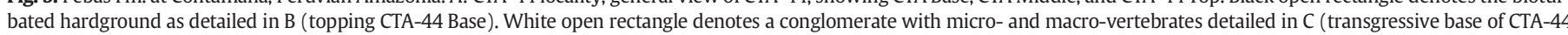

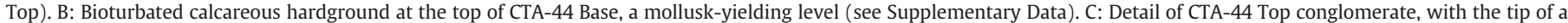
Purussaurus tooth cropping out in-situ. D: Detail of the oyster-rich level in CTA-58. Note that the individuals of Crassostrea have their valves paired and connected.

immigrant was recognized in the deposits ascribed to the Pebas Fm. in the Contamana area (Supplementary Data), but a lower molar of an indisputable trichechid sirenian was unearthed in the lowermost level (CTA-63).

3.1.4.3. Age. Thirteen fossil-yielding localities in the Contamana area are assigned to the Pebas Fm. (Fig. 3; Table 1; Supplementary Data). They document at least eight successive levels in a single section (SW of the Maquia Anticline; Fig. S1), which can be gathered into four clusters (CTA-63 [early Miocene]; CTA-09 + CTA-45 [late early/early middle Miocene]; CTA-44 Base + CTA-44 Middle + CTA-58 + CTA-77 [middle/late Miocene transition]; CTA-44 Top + CTA-43 + CTA-58 + CTA$10+$ CTA-76 + CTA-75 [early late Miocene]). These localities are distributed over a long stratigraphical interval, as they range from the early Miocene (Colhuehuapian-Santacrucian SALMAs; $2017 \mathrm{Ma}$ ) up to the late Miocene (Mayoan/Chasicoan SALMAs; 11-9 Ma).
The early Miocene age of CTA-63 is mostly constrained by its rodent assemblage, with the octodontoid Protadelphomys sp. (Colhuehuapian SALMA; Vucetich and Bond, 2013; Arnal et al., 2014) and a relatively low-crowned dinomyid comparable to Scleromys quadrangulatus from Patagonia and Peruvian Amazonia (post-Colhuehuapian/preSantacrucian 'Pinturan' stage; Kramarz, 2006; Marivaux et al., 2012). The glyptodontid Parapropalaehoplophorus sp. was also restricted to the Santacrucian SALMA (Chucal Fm., Chile; Croft et al., 2007) before two osteoderms late middle Miocene in age were referred to as the same taxon by Tejada-Lara et al. (2015; Laventan SALMA, Fitzcarrald local fauna, Peru).

Contrary to the underlying localities CTA-09 and CTA-45, which are poorly age-constrained and assumed to be late early to middle Miocene in age (mainly based on their position in the section), CTA-44 has yielded three successive assemblages of high biostratigraphic interest. The mollusks of CTA-44 Base are latest middle Miocene in age (mollusk zone

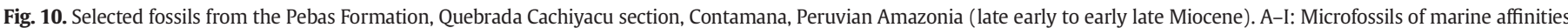

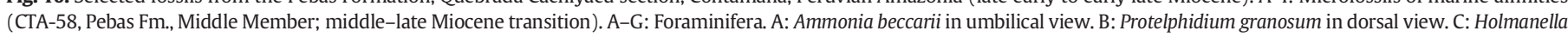

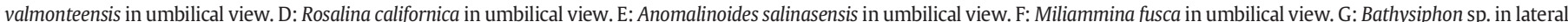

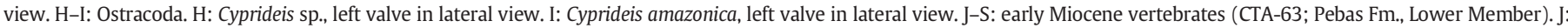

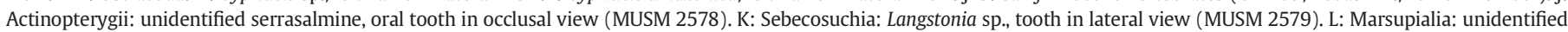

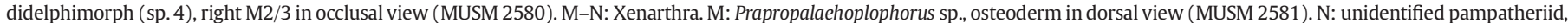

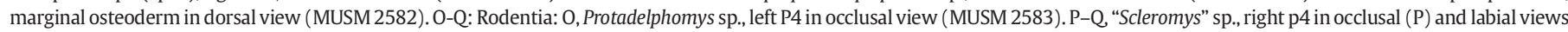

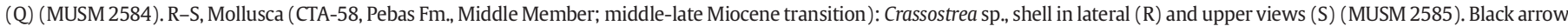

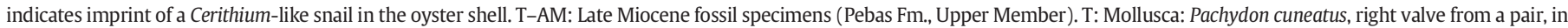

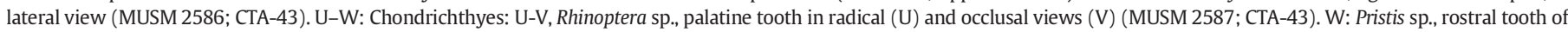

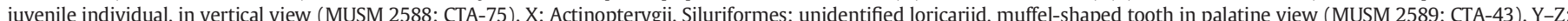

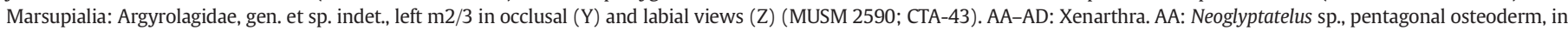

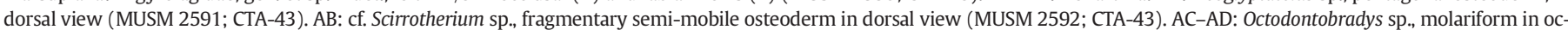

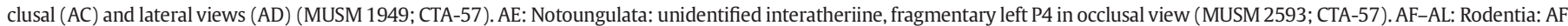

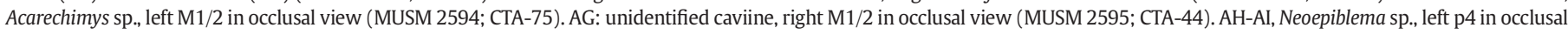

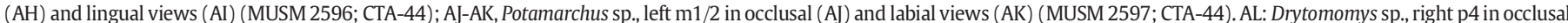

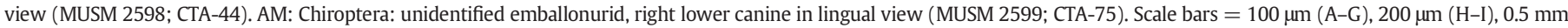
(O, AF), 1 mm (L, X-Z, AE, AG, AM), 2 mm (J, P-Q AA-AB, AJ-AK), 5 mm (K, M-N, W, AH-AI, AL), 10 mm (R-V, AC-AD). 
MZ8, 12 Mya; Wesselingh et al., 2006), the microfossil assemblage of CTA-44 Middle is most probably recording the middle-late Miocene transition (pollen and foraminiferans; Supplementary Data), and the mammalian fauna of CTA-44 Top documents the earliest late Miocene (Mayoan SALMA; rodents Neoepiblema, Potamarchus, and Drytomomys). Laterally equivalent localities, CTA-58 and CTA-77, yielded mollusks, Pebasian ostracods, and palynomorphs pointing to a similar age (middle-late Miocene transition; Fig. 2; Supplementary Data).
The species-rich locality CTA-43, located $24 \mathrm{~m}$ above CTA-44 Top in the same section, is most probably earliest late Miocene in age (Mayoan SALMA). There co-occur taxa of late middle Miocene affinities (Laventan SALMA; hypselodont argyrolagid marsupial: Sánchez-Villagra et al., 2000; Steiromys, Acarechimys, Scirrotherium, and Neoglyptatelus: Madden et al., 1997) and of late Miocene/Pliocene affinities (Chasicoan SALMA onward; eumegamyine rodents: Zárate et al., 2007; caviine cavioid: Pérez and Pol, 2012). A similar age is hypothesized for CTA-
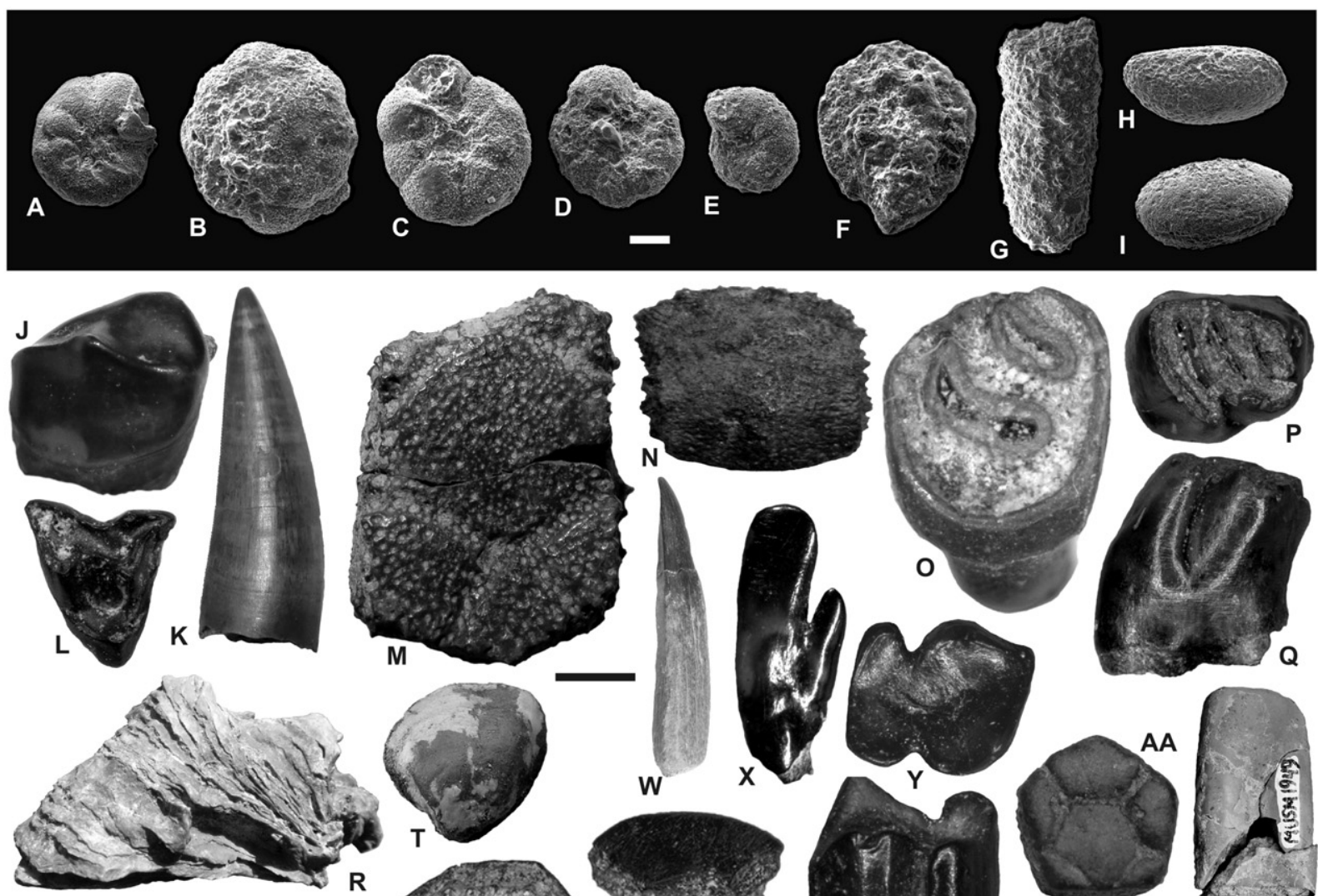
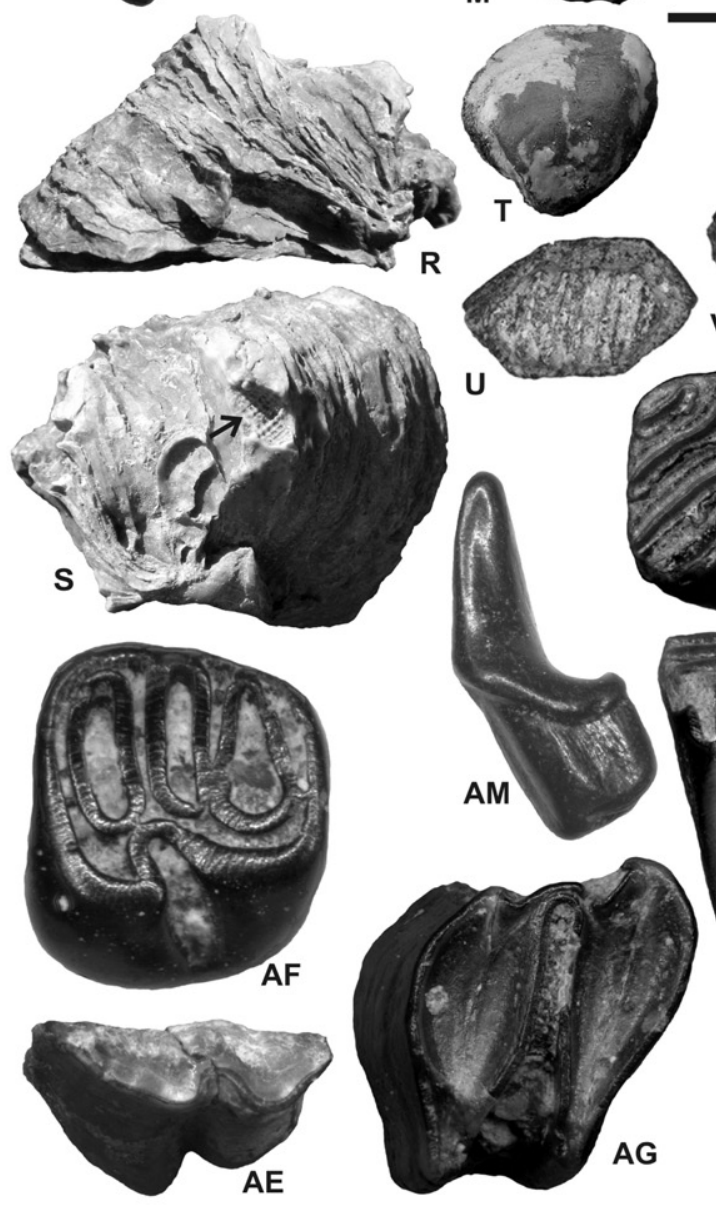

AG
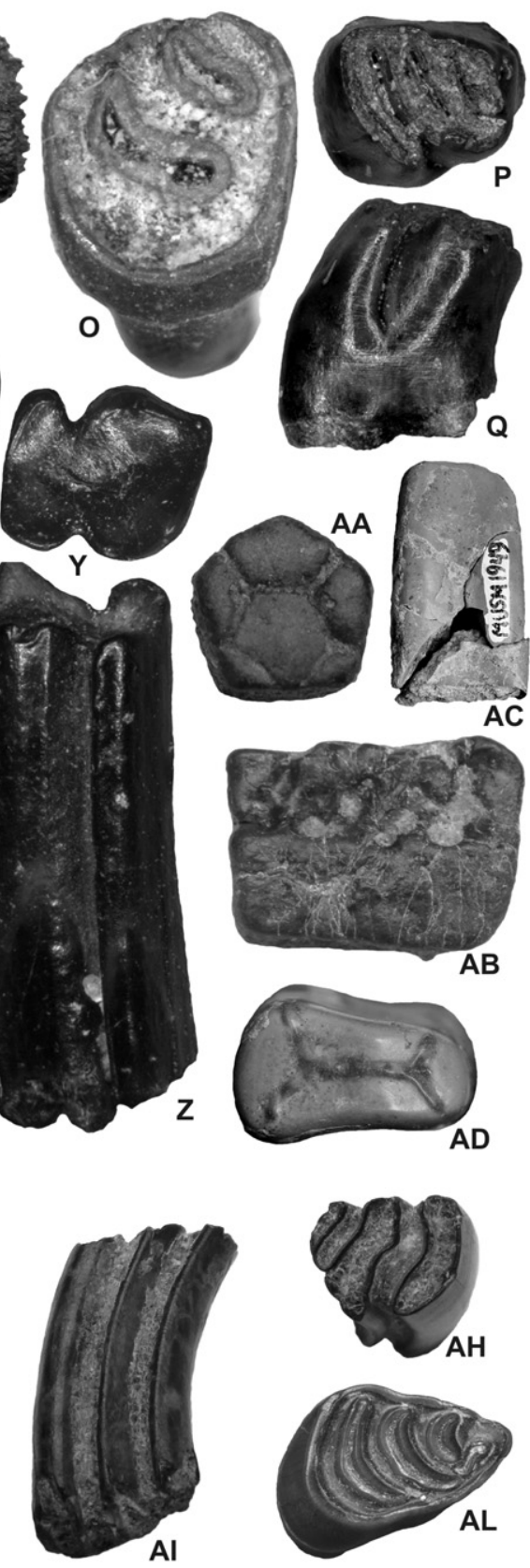
57. The uppermost localities ascribed to the Pebas Fm. (CTA-10, CTA-76, and CTA-75) are considered not to be significantly younger than CTA43, as they notably include the same representatives of Acarechimys and Potamarchus as the latter locality (Fig. 10AF, AJ-AK; Supplementary Data), further supporting a high sedimentation rate for the concerned interval. The seismite level that is cropping out between CTA-43 and CTA-76 attests to a tectonic activity, suggesting that thrust tectonic movements were active by early late Miocene times, which is in agreement with data available for the Central Andes (Mora et al., 2010; Espurt et al., 2011; Armijo et al., 2015) and the northern Peruvian Subandean Zone (Eude et al., 2015).

3.1.4.4. Depositional environments. Blue clays with thin lignite seams and pyrite nodules (e.g., CTA-63 and CTA-44 Base; Fig. 9A) are strikingly reminiscent of early and middle Miocene fossiliferous deposits from the Pebas Fm. in the Iquitos area (e.g., Antoine et al., 2006; Wesselingh et al., 2006; Salas-Gismondi et al., 2015). Conversely, other fossilyielding levels, essentially consisting of unconsolidated and unsorted conglomerates and sandstones (e.g. CTA-45, CTA-44 Top, CTA-43, CT76 , or CTA-75) in the Cachiyacu section, are likely to document transgressive lags. They are much similar to the late middle Miocene Fitzcarrald bone beds in terms of organization and thickness (referred to the Ipururo Fm.; Fig. 1B; Espurt et al., 2007, 2010; Pujos et al., 2013; Tejada-Lara et al., 2015).

The laminated blue siltites with leaf litter in CTA-45 are particularly rich in organic matter.

Environments may change drastically within a single outcrop (CTA-44, 10 m-thick; Fig. 9A-C; Supplementary Data), with successive levels documenting $(i)$ a lake shore (CTA-44 Base: mollusk assemblage within a carbonated hardground; Fig. 9B), (ii) a coastal plain with marginal marine affinities (CTA-44 Middle: pollen, foraminiferans, and dinoflagellate assemblage), (iii) a channelized estuarine embayment (CTA-44 Top: vertebrate assemblage with a mixture of terrestrial, riverine, and marine taxa; Fig. 9C), and (iv) a channel experiencing instant floodings as attested by the $3 \mathrm{~m}$-thick topping conglomerate, with pluri-decimetric clay pebbles wrenched off from close upstream banks (Figs. 9A, S1). Similarly, in CTA-76 (Upper Member), a coarse conglomerate overlies a bivalve-rich bed within ochre sands showing an oblique stacking pattern typical of a unidirectional stream.

In CTA-58, 21 foraminiferan species co-occur, dominated by Ammonia, and ostracods of mesohaline-euryhaline affinities (e.g., Perissocytheridea acuminata, Rhadinocytherura amazonensis; Gross et al., 2013). The ostracod assemblage is strikingly reminiscent of that from a marine interval recognized in coeval deposits of Western Brazil (Solimoes Fm.; Linhares et al., 2011). The dinoflagellate Spiniferites sp. (CTA-44 and CTA-58) and unidentified urchins (spines; CTA-58) further attest to marine affinities. Accordingly, Crassostrea oysters from CTA-58 (Fig. 9D) and CTA-77 are perforated by clionid demosponges and covered by serpulid annelid tubes. One of them bears an imprint of a Cerithium-like gastropod (Fig. 10RS).

The top of the Pebas Fm. as observed in the SW flank of the Maquía Anticline is marked by calcrete-rich paleosols (CTA-75).

3.1.4.5. Correlation. The Pebas Fm. was formerly named in the IquitosPebas area. It is correlated with the Solimoẽs Fm. in northwestern Brazil; in most recent works illustrating the PMWS, marine incursions and tectonic pulses are considered as major markers for intra-basin correlation between Peru, Brazil, Colombia, Ecuador, and Bolivia (Hoorn et al., 2010b; Roddaz et al., 2010; Boonstra et al., 2015; Salas-Gismondi et al., 2015).

\subsubsection{Ipururo Formation (late Miocene-?early Pliocene)}

3.1.5.1. Description. The Ipururo Fm. crops out extensively in the SW flank of the Maquía Anticline (Fig. 2), and along the tracks in the close outskirts of Contamana. The concerned deposits conformably overlie those of the Pebas Fm. They are dominated by more or less friable gray conglomerates and sandstones intercalated with yellowish and brown paleosols, and dominated by quartz, crystalline rock, and clay pebbles. These levels are strongly folded, with dips exceeding $45^{\circ}$ downstream the Quebrada Cachiyacu and close to the Río Ucayali (Fig. 2), in accordance with the observation of Kummel (1948: 1258). Based on available surface data (exposures and dips), their total thickness may exceed $1,200 \mathrm{~m}$. There is no exposure on the right bank of the Río Ucayali, at least in the Contamana area.

3.1.5.2. Paleontological content. The fossil record is so far very poor within the Ipururo Fm. in the Contamana area, with only two successive fossilyielding localities recognized in the SW flank of the Maquía Anticline (Figs. 2, 3). The lowermost locality is CTA-42, located $\sim 160 \mathrm{~m}$ above CTA-75 (i.e., the uppermost level ascribed to the Pebas Fm.), in the same section. There, a freshwater trichodactylid crabs, a fish-eating longirostrine crocodylomorph, and an unidentified caiman co-occurred (Supplementary Data). A mandibular fragment of a small representative of Caiman was unearthed in CTA-59, $200 \mathrm{~m}$ above CTA-42 (Figs. 2, 3).

3.1.5.3. Age. No direct age constraint is available for the Ipururo Fm. in Contamana. Nevertheless, as it conformably overlies Pebas deposits and exceeds $500 \mathrm{~m}$ in terms of thickness, it is likely to document a long late Neogene interval (late Miocene-?Pliocene). Additional proxies, however, are needed for a reliable age constraint.

3.1.5.4. Depositional environment. Sedimentological data and paleontological evidences suggest fluvial depositional environments, alternating with floodplains and paleosols throughout the Ipururo Fm. The lack of preservation of organic matter in the levels sampled for palynology (CTA-42, CTA-59, and CTA-70; Figs. 3, S1) could suggest a fully fluvial environment with seasonal fluctuation of the water level. The available data do not point to marine episodes in the Contamana area during the concerned time interval.

\subsubsection{Ucayali Formation (?late Pliocene-Pleistocene)}

We have not thoroughly investigated the Ucayali Fm., i.e., the uppermost formation cropping out along the right bank of the Río Ucayali in the Contamana region, neither from a paleontological perspective nor for stratigraphy. The corresponding fluvio-lacustrine settings form horizontal terraces unconformably overlying deposits of the Ipururo Fm. (Fig. 2; Kummel, 1948). Their hypothesized thickness does not exceed $75 \mathrm{~m}$, which coincides with the height of the highest terraces, SE to Contamana (Fig. 2). To our knowledge, no fossil content was described in the concerned deposits, except for some vertebrate specimens unearthed in a remote area of the Ucayali Basin (Río Pachitea; Spillmann, 1949). Besides, the field-based description by Kummel (1948), a recent review of the concerned unit and equivalent formations (e.g., Marañon Fm.) at the Western Amazonian scale is available in Roddaz et al. (2010).

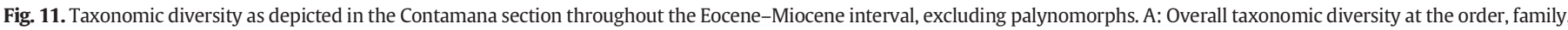

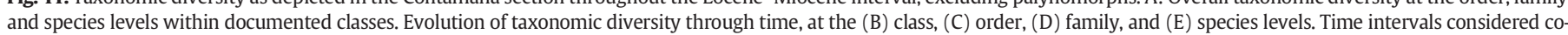

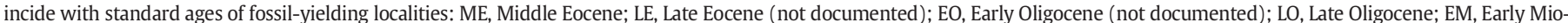

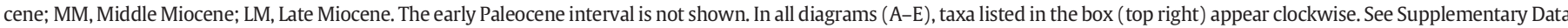
for further details. 


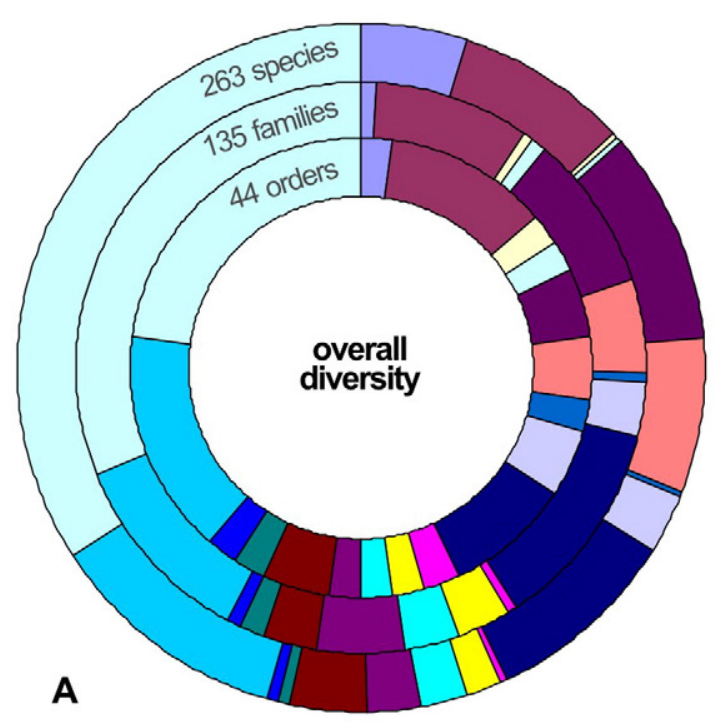

$\square$ Charophyta

$\square$ Foraminifera

$\square$ Porifera

$\square$ Annelida

Mollusca

$\square$ Crustacea

$\square$ Echinodermata

$\square$ Chondrichthyes

actinopterygii

$\square$ Dipnoi

$\square$ Amphibia

$\square$ Chelonia

$\square$ Lepidosauria

Crocodylia

$\square$ Aves

Allotheria

$\square$ Metatheria

$\square$ Eutheria
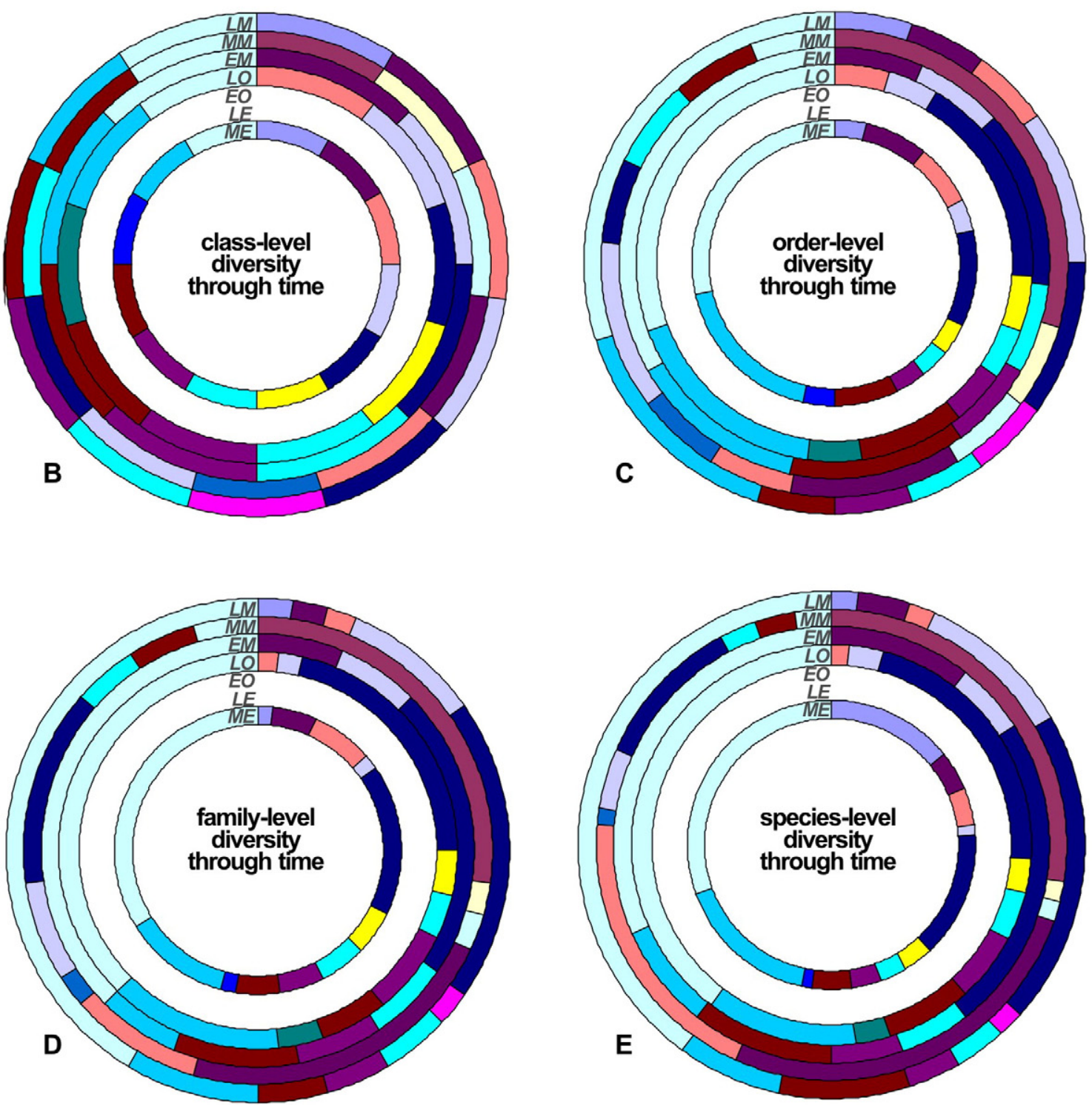


\section{Discussion}

\subsection{Taxonomic diversity trends (Eocene-Miocene)}

The overall taxonomic diversity in the Contamana section and its evolution throughout the Eocene-Miocene interval (excluding palynomorphs) are depicted in Fig. 11 at the class/infraclass, order, family, and species levels. The time intervals considered coincide with welldiversified fossil-yielding locality clusters, i.e. the middle Eocene (Pozo Fm., Lower Member), the late Oligocene (Chambira Fm., Lower Member), the early Miocene (Pebas Fm., Lower Member), the middle Miocene (Pebas Fm., Middle Member; somewhat biased by a poor fossil record regarding vertebrates), and the late Miocene (Pebas Fm., Upper Member + Ipururo Fm.). We have chosen not to include the Paleocene Huchpayacu Fm., as its fossil record is both virtually undocumented and presumably highly biased (CTA-54, charophyte-dominated; Supplementary Data).

As illustrated in Fig. 11B, the middle Eocene, late Oligocene, early Miocene, middle Miocene, and late Miocene assemblages display a fairly constant higher-level taxonomic diversity throughout the period documented (ranging from 8 to 12 classes or infraclasses; Supplementary Data). Order-level diversity fluctuates to a greater degree, with a decline in the early and middle Miocene ( 15 and 17 co-occurring orders, respectively) compared to earlier intervals ( 28 in the middle Eocene; 23 in the late Oligocene) and the late Miocene (20 co-occurring orders; Fig. 11C). Nevertheless, this first-order analysis does not take into account the replacement of terrestrial vertebrates by aquatic organisms with marine or fluvio-lacustrine affinities in the "Pebasian" interval (early and middle Miocene). In other words, overall diversity might be comparable but with strikingly distinct components: non-vertebrate taxa of marine affinities during the early and middle Miocene interval (PMWS: dinoflagellates, foraminiferans, most ostracods, serpulid polychetes, ostreids, and demosponges; Supplementary Data) as opposed to a vertebrate-dominated biota during earlier and later intervals (Fig. 11B-E; Table S2).

At the family/species level, the richest interval is the middle Eocene one with 59/92 co-occurring taxa. This huge diversity is maintained during the late Oligocene ( 56 families encompassing 73 species), but with a stronger vertebrate component (Fig. 11D-E). The lowest family/species diversity (32/38) is recorded during the early Miocene. The drastic drop in species/family diversity recorded then might result from the coincidence of at least two factors: (i) a sustainable environmental change occurred at regional scale with the onset of the lacustrine-dominated Pebas Mega-Wetland System. The latter replaced fully fluvial-dominated conditions prevailing until then, which most likely affected both the aquatic and terrestrial components of the ecosystems (Wesselingh et al., 2006; Hoorn et al., 2010a,b; this work); (ii) there is an obligate sampling bias, as the early Miocene interval comprises only one species-rich locality in our analysis (CTA-63) whereas we have grouped CTA-09 and CTA45 (of uncertain age: late early or early middle Miocene) with unequivocal middle Miocene localities (CTA-44 Base, CTA-44 Middle, CTA-58, and CTA-77; Supplementary Data). By contrast, the middle and late Miocene intervals document increasing diversity with 44 and 46 co-occurring families, respectively. Species-richness is higher during the middle Miocene (76) than the late Miocene (60), due to the occurrence of polytypic/plurispecific ostracod and foraminiferan genera in the former interval (Fig. 11A, E). In general, overall familyand-species diversity declines throughout the concerned interval, with a drastic drop in the early Miocene ( 32 families/38 species). This compares with 59/92 and 56/73 in earlier Paleogene time slices and 44/76 and 46/60 taxa in later time slices (middle and late Miocene, respectively; see Supplementary Data).

From a taxonomic perspective, charophytes only occur in the early Paleocene + middle Eocene interval, with a comparable diversity (13-14 species; Table 2; Fig. 11B). Trichodactylids are abundant in all intervals except the early and middle Miocene (absent). Chondrichthyes increase in diversity through time: only freshwater potamotrygonids are present during the Paleogene interval, whereas dasyatids, myliobatids, and pristids (of marine affinities) occur in all Miocene time slices (along with potamotrygonids; Fig. 11D-E). The actinopterygian ichthyofauna (mainly characiforms and siluriforms) is relatively invariant throughout the concerned interval in terms of taxonomic content (Fig. 11C-E), in contrast to the highly fluctuating chondrichthyan component. However, no siluriform has yet been recorded from the early Miocene. Dipnoi are only recognized in the late Miocene period (CTA-44).

The amphibian (anuran) record in the Contamana area is restricted to the Paleogene interval (Supplementary Data; Fig. 11B-E): no Neogene representative has been unearthed so far.

Chelonia and Lepidosauria are not identified precisely enough to allow for a significant interpretation in terms of diversity trends. Crocodylomorphs are a consistent component of Contamana assemblages at any taxonomic level (Fig. 11B-E), with a sebecid (closely allied to either Sebecus in Paleogene localities or Langstonia in Miocene ones), caimanines (generalist and/or malacophagous), and gharials cooccurring in most cases.

In general, mammalian diversity appears to have reached a climax during Paleogene times in the Contamana area (Fig. 11), with 14/28/ 44 middle Eocene and 11/29/38 late Oligocene orders/families/species, compared with 7/14/15 early Miocene, 1/2/2 middle Miocene, and 9/ 23/28 late Miocene co-occurring orders/families/species. Even taking into account that the early and middle Miocene interval is likely under-sampled, the late Miocene mammalian assemblage is impoverished with respect to its Paleogene counterpart, as many endemic taxa had apparently disappeared by that time, and northern GABI-induced immigrants have not yet been documented. In particular, potential allotherians (?sudamericid gondwanatheres) are restricted to the earliest interval (middle Eocene; Supplementary Data). Similarly, Metatheria are well-represented and widely diversified in Paleogene localities (5/4 co-occurring orders, $7 / 8$ families, and $15 / 9$ species in the middle Eocene/late Oligocene, respectively), whereas they are much rarer (zero to four species) in Miocene assemblages (Fig. 11B-E; Supplementary Data). Xenarthrans are never abundant, and their taxonomic diversity does not vary throughout the documented range. Cingulates are dominant over sloths (but this may be a taphonomic bias as the former are only documented by osteoderms; Gaudin and Croft, 2015). Three cingulate families co-occur with mylodontoid sloths from the late Oligocene onward. Among South American native ungulates, notoungulates are by far the most diversified in Contamana localities, with a family/species diversity decreasing abruptly at the OligoceneMiocene transition. Both the 'trigonostylopid' astrapothere and pyrotheres are restricted to the earliest documented interval (middle Eocene), in good agreement with their record at the South American scale (e.g., Kramarz et al., 2011).

Rodents provide a much better sketch in both a taxonomic and biostratigraphic perspective. There is no common taxon between the middle Eocene and the late Oligocene assemblages (stem caviomorphs vs. representatives of Recent superfamilies), whereas a relative continuity is observed between the late Oligocene and the early Miocene. Dinomyids characterize Neogene localities at Contamana, in agreement with both the Argentinian and Brazilian fossil records (e.g., Kerber et al., 2015). Their generic diversity increases throughout the Miocene interval. Dasyproctidae and Neoepiblemidae are only documented in late Miocene localities.

Bats are rare but do occur throughout the documented period, except during the under-sampled middle Miocene interval (absent), with up to three co-occurring families and species. Two intervals have yielded primates (late Oligocene, late Miocene) with two species recorded in both cases (Supplementary Data). A single trichechid sirenian specimen was identified throughout the documented section (Pebasian interval). 


\subsection{Paleoenvironmental inferences}

\subsubsection{Depositional environments}

Based on the observations of the previous section, depositional environments can basically be grouped in three distinct clusters:

- (i) fluvial settings, testifying to the occurrence of depositional environments highly comparable to the recent ones of the Quebrada Cachiyacu;

- (ii) lacustrine settings (oxbow lakes or piranha-rich "cochas");

- (iii) bay margin/coastal settings (blue clays with lignitic seams and a mixture of fossil remains of terrestrial, freshwater, and marine affinities; transgressive lags).

Together with lithology in general, mollusks, ostracods, and charophytes are the best markers for defining the geological formations in the Contamana area:

- Lower Huchpayacu Fm.: carbonates that preserve numerous charophytes but almost no mollusks and no palynomorph; dysoxic lacustrine environments;

- Pozo Fm. ('Pozo Sands'): sedimentation dominated by floodplain deposits transformed into variegated paleosols intercalated with channelized fluvial sandstones; diagenetic millimetric carbonate nodules are preserved, with numerous palynomorphs, (secondarily silicified) charophyte oogonia, ostracods, and mollusks (inner casts no shell preserved);

- Chambira Fm.: sedimentation dominated by polygenic conglomerate channels and floodplain deposits, transformed into red paleosols with anhydrite veins; no carbonates, palynomorphs, charophytes, ostracods, or mollusks are preserved;

- Pebas Fm.: sedimentation dominated by red-grayish paleosols and blue clays (with pyrite nodules and lignitous lenses); carbonates may occur (nodules and hardgrounds); mollusks are abundant and diversified (shells preserved; bivalves + gastropods); palynomorphs are diverse and well-preserved; foraminiferans, dinoflagellates, and brackish to marine ostracods are abundant; no charophytes preserved, except in one locality;

- Ipururo Fm. + Ucayali Fm.: sedimentation dominated by coarser deposits (conglomerates intercalated with sandstones and siltstones) rather than floodplain deposits); no carbonates, palynomorphs, charophytes, mollusks, or ostracods.

\subsubsection{Paleoenvironments as inferred by organisms}

Based on recent biomes, consensual inferences regarding fossil organisms recovered, and lithology (Table S4), we have considered ten hypothetical biotopes a priori, either terrestrial (high-elevation range, savanna, rainforest), aquatic (freshwater: lake/pond, river/small stream; brackish: delta/estuary, coastal plain; marine: inner shelf), or at the interface between two of them (floodplain, mangrove). This allows for sketching landscape evolution in Contamana during the Cenozoic.

The Contamana area was fully dominated by freshwater environments within a tropical rainforest throughout the concerned period (Table S4): primarily rivers and small streams (early PaleoceneRecent), but also lakes (early Paleocene; late Oligocene; Miocene). Floodplains are inferred from the occurrence of "terrestrial" crocodiles (sebecids) and tree stumps (middle Eocene; late Oligocene; early Miocene) in fine-grained paleosols. There is no clue for any high-elevation (Andean), mangrove, or open terrestrial habitats (savanna or "chaco"), at least from the palynological record (Tables S3-S4). Although other biotic components consistently point to a tropical rainforest (with brackish/marine inputs; Table S4), the co-occurrence of mammals with evergrowing teeth, such as argyrolagid marsupials or dinomyid and caviine rodents, indicates a higher rate of abrasive food (dust/ashes) at the end of the Pebasian interval (CTA-44 Top and CTA-43; early late Miocene).
Marine influence is suggested during the middle Eocene (coastal plain/marginal marine: dinoflagellates in CTA-47; ostracod in CTA-27) and strongly evidenced during the middle Miocene (CTA-45: brackish water rays) and around the middle-late Miocene transition (co-occurrence of a wide array of marine organisms in CTA-44 Middle, CTA-58, and CTA-77; Table S4).

\subsubsection{Correlation with other Amazonian sub-basins}

A marine corridor bordered the eastern flank of the Proto-Andes during the late Cretaceous, as shown extensively from Argentina to Colombia (e.g., Lundberg et al., 1998; Hoorn et al., 2010a; Louterbach et al., 2014). Accordingly, marine deposits are recorded in the NPFB (Lundberg et al., 1998), SPFB (based on selachian ichthyofauna; Louterbach et al., 2014), and Ucayali basin (Kummel, 1948). It seems that this shallow seaway withdrew around the Cretaceous/Paleogene transition (Lundberg et al., 1998), which is supported by the early Paleocene record of the Contamana area (Huchpayacu Fm., base; Fig. 12). Unfortunately, the present study provides no data for the middle Paleocene-early Eocene interval; although tidal sands assigned to the Casa Blanca Fm. (and thus coinciding with the corresponding interval; Fig. 12) are cropping out in other parts of the Ucayali Basin (Pachitea; Kummel, 1948), it is so far impossible to test whether a connection existed with either the NPFB (Paleocene continental and Eocene marine-dominated sedimentation; Roddaz et al., 2010) or the SPFB (late Paleocene marine incursion; e.g., Louterbach et al., 2014). Conversely, independent sub-basin dynamics between the NPFB and the Ucayali Basin can be assumed during the middle Eocene (well-documented and time-constrained in Contamana), and perhaps the late Eocene as well (Fig. 12). By late Oligocene and earliest Miocene times, sedimentation seems to have been homogenous throughout Peruvian lowlands and Subandean zones, with the fluvial-dominated Chambira deposits. The PMWS subsequently developed in both the NPFB and the Ucayali Basin between the late early and early late Miocene (Fig. 12; Antoine et al., 2013). At least from a paleontological perspective, no Pebasian influence is recorded in the SPFB, as the southernmost assemblage of ascertained Pebasian affinities was mentioned at Sepahua on the Río Urubamba (middle Miocene mollusks, $11^{\circ} 10^{\prime} \mathrm{S}$; Wesselingh et al., 2006). An early late Miocene marine incursion is recorded throughout the NPFB and Ucayali Basin (Fig. 12; Boonstra et al., 2015 and this work), testifying to a single event, perhaps distinct from the later one(s) documented in the SPFB (e.g., Hovikoski et al., 2010). From Pliocene times onward (initiated at $4 \mathrm{Ma}$; Espurt et al., 2007; Roddaz et al., 2010), the Fitzcarrald Arch was uplifted as a pivotal topographic high at the Western Amazonian scale, which may explain the discrepancies between the Ucayali basin, connected with the NPFB, and the Madre de Dios basin (SPFB).

\subsection{Paleobiogeography}

The fossil assemblages documented in the Paleocene-?Pliocene interval in the Contamana area attest at least to four biogeographic histories, sometimes interwoven and inherited from (i) Mesozoic Gondwanan times, (ii) the Panamerican realm prior to (iii) South America's Cenozoic "splendid isolation", and (iv) Neotropical ecosystems in the Americas.

\subsubsection{Gondwanan faunal and floral components}

Aquatic taxa are the most conspicuous biotic elements of Gondwanan affinities in the Contamana section (charophytes, neritid gastropods and hyriid bivalves, cichlid actinopterygians, lepidosireniform lungfishes, plus chelid and podocnemidid turtles), in agreement with the conclusions of Brito et al. (2007) and Sterli and de la Fuente (2013). Similarly, pipid anurans occur only in South America and Africa (recent: San Mauro et al., 2005; fossil: Rage et al., 2013). Specimens assigned to that family are relatively common in middle Eocene assemblages of the Contamana area, whereas no post-Eocene remains have been discovered so far (Supplementary Data). 


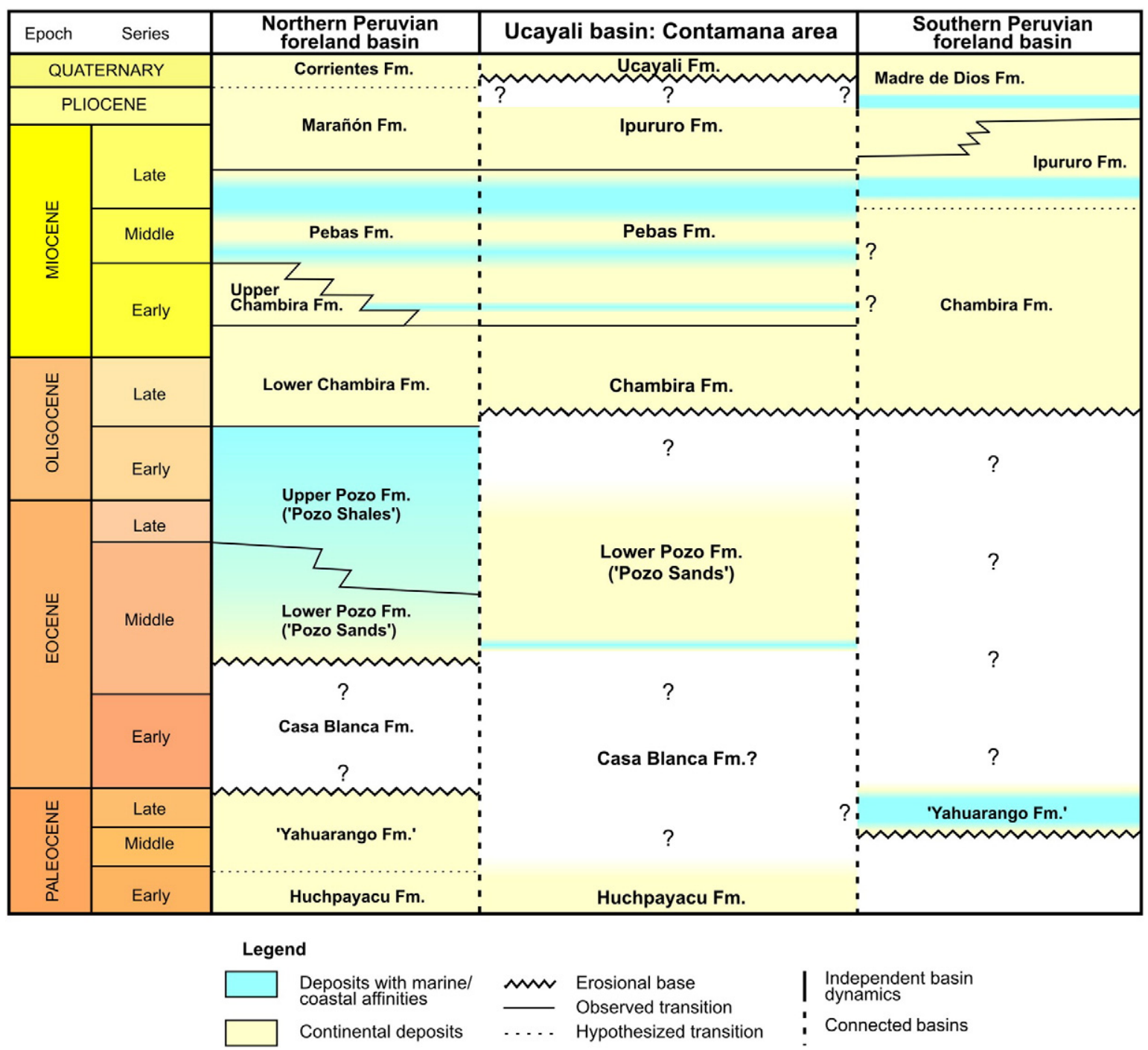

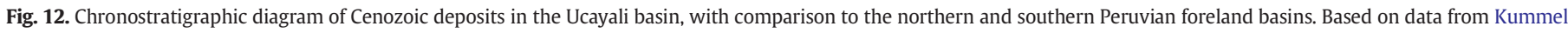

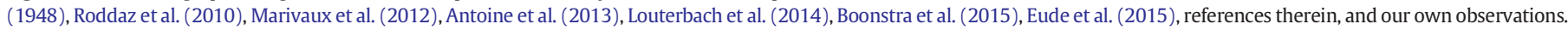

Some terrestrial mammals, such as polydolopimorphian and microbiotherian marsupials, also attest to a Gondwanan legacy (also recorded in Australia and Antarctica; e.g., Archer et al., 1999; Goin et al., 1999, 2007; Sigé et al., 2009).

\subsubsection{Panamerican heritage (and Holarctic outliers)}

The Contamana Paleogene record supports a latest Cretaceousearly Cenozoic North American pathway for aquatic/freshwater taxa, such as corbulid bivalves (Pachydon group), freshwater stingrays (Potamotrygonidae; Table S2), and crocodylomorphs (durophagous caimanines), as already mentioned by Adnet et al. (2014) and SalasGismondi et al. (2015), and supported by geological evidence in Northern South America (Cardona et al., 2010; Bayona et al., 2011). The fact that interchanges between South and North America involved freshwater animals confirms that a continuous, well established terrestrial connection linked the two continents at that time (Gayet et al., 1992). The occurrence of possible herpetotheriid metatherians, of Holarctic/North American affinities in the late middle Eocene of Contamana (Supplementary Data), further supports the hypothesis of a terrestrial connection between these landmasses during the same interval (see also Goin and Candela, 2004; Sánchez-Villagra et al., 2007). Likewise, recent collagen-based phylogenetic studies point to close relationships of litopterns and notoungulates with Perissodactyla among Laurasiatheria, of undisputed
Holarctic affinities, with a split around the Cretaceous-Paleogene transition (Buckley, 2015; Welker et al., 2015).

If confirmed, the presence of a probable rhinolophoid microchiropteran bat in the late Oligocene of Contamana (CTA-32; Supplementary Data) would considerably expand the geographic range of the superfamily, so far restricted to the Old World (Ravel et al., 2014), though clearly the dispersal ability of bats is in no way comparable to that of scansorial or freshwater organisms (Calderón-Patrón et al., 2013).

\subsubsection{South American endemics}

Other components of the freshwater ichthyofauna recovered in Contamana, such as Potamotrygonidae sensu stricto, anostomid characiforms, and lepidosirenids, have a biogeographical history restricted to South America (Sidlauskas and Vari, 2008; Albert and Reis, 2011; Adnet et al., 2014). Also trichodactylid freshwater crabs are considered as autochthonous South American faunal elements (Klaus et al., 2011). The anilioid squamate from CTA-27 and sebecid mesoeucrocodylians have a similar range (Pol and Powell, 2011; Wallach et al., 2014). The mammalian fauna from the Contamana series also has a strong South American signature, with bonapartherioid and argyrolagid polydolopimorphians, paucituberculatans, and sparassodonts (e.g., Beck, 2012), but also South American native 
ungulates, such as pyrotheres and astrapotheres - possibly closely related to notungulates though (Billet, 2010) and, as such, to perissodactyls (Buckley, 2015; Welker et al., 2015). South American endemics are recorded as early as the middle Eocene in the Contamana area.

Our results are consistent with most recent paleogeographical maps for middle-late Miocene times (Antoine et al., 2013; Boonstra et al., 2015; Salas-Gismondi et al., 2015) in showing that the Contamana area was unambiguously part of the PMWS during a long interval (late early to early late Miocene). In particular, most ostracods, mollusks, and crocodylomorphs found in Contamana are Pebasian endemics (Wesselingh and Ramos, 2010; Salas-Gismondi et al., 2015).

\subsubsection{Neotropical markers - no evidence for the Great American Biotic Interchange}

Most actinopterygian clades documented in Contamana (serrasalmine, cynodontid, and erythrinid characiforms, but also loricariid and pimelodid siluriforms; Albert and Reis, 2011) have a South American Neotropical distribution today. Due to the closure of the Central American seaway in the Pliocene or perhaps even in Miocene times as suggested by Bacon et al. (2015) and Montes et al. (2015), these groups have subsequently dispersed into Central and North America. A similar scenario might be hypothesized for teiid lizards (Pujos et al., 2009), caimanine crocodylians (Salas-Gismondi et al., 2015), didelphimorphian marsupials (Sánchez-Villagra et al., 2007), and notoungulates (MacFadden, 2006). The xenarthran, caviomorph and platyrrhine biogeographic history appears to be much more complicated, with a South American differentiation and several subsequent dispersals to Caribbean islands, Central America, and/or North America during the Oligocene-Pleistocene interval (MacFadden, 2006; Antoine et al., 2012; Vélez-Juarbe et al., 2014).

Trichechid sirenians are fully aquatic and their fossil record encompasses both the Paleotropics and the Neotropics (e.g., Vélez-Juarbe, 2014). Nevertheless, the recognition of an early Miocene trichechine in the Cachiyacu section (CTA-63) supports the hypothesis of a Neotropical origin for manatees (e.g., Domning, 2005; Vélez-Juarbe, 2014). This record also pushes the presence of trichechines in South America from the middle Miocene (Domning, 1982) back to the early Miocene, implying that the group may have a more complex evolutionary history on the continent.

Conversely, based on the available samples, we have not documented direct evidence for North American terrestrial immigrants into the tropical rainforests of Peruvian Amazonia during the Miocene interval in Contamana that could coincide with an early onset of the Great American Biotic Interchange during the middle or late Miocene (Supplementary Data; Carrillo et al., 2014).

\section{Acknowledgements}

We are much indebted to the editors of Gondwana Research, M. Santosh, and T. Horscroft, for inviting this review. Two anonymous reviewers have provided interesting and constructive remarks.

We are particularly grateful to the Canaan Shipibo Native Community and Maple Gas Peru S.A. for granting access to the field, and to the IRD-PeruPetro Convention Programme for logistic support. We thank warmly our guides Manuel and Manuel, Joaquin Sanancino, their families, and whoever helped us in the field and in the lab. This article is dedicated to the memory of Eduardo "Aldo" Musacchio. This work was supported by CNRS 'Eclipse 2', CNRS 'Paleo2', Toulouse University 'SPAM' programs, by ANR-08-JCJC-0017 (PALASIAFRICA) program, by the Alexander von Humboldt-Foundation (Bonn), and by an "Investissements d'Avenir" grant managed by Agence Nationale de la Recherche (CEBA, ANR-10-LABX-25-01).

POA, PB, CJ, LM, and RSG designed research. POA, SA, AJA, PB, GB, YC, DAC, CJ, LM, MJO, FPu, MR, JVT-L, and RSG participated in the fieldwork. POA, AA, SA, AJA, GB, MB, AC, JC, DAC, CJ, SK, LM, REN, FPa, MEP, FPu, JCR, AR, CR, JVT-L, JVJ, FPW, and RSG helped with taxonomic identification and specimen illustration. POA, PB, YC, and MR measured the sections. FC and MG performed radioisotopic datings. POA, FC, CJ, LM, REN, FPa, MR, FPW, and RSG wrote the manuscript. This is ISEM publication 2015-236 SUD.

\section{Appendix A. Supplementary data}

Supplementary data to this article can be found online at http://dx. doi.org/10.1016/j.gr.2015.11.001.

\section{References}

Adaci, M., Tabuce, R., Mebrouk, F., Bensalah, M., Fabre, P.-H., Hautier, L., Jaeger, J.-J., Lazzari, V., Mahboubi, M., Marivaux, L., Otero, O., Peigné, S., Tong, H., 2007. Nouveaux sites à vertébrés paléogènes dans la région des Gour Lazib (Sahara Nord-occidental, Algérie). Comptes Rendus Palevol 6, 535-544.

Adnet, S., Salas Gismondi, R., Antoine, P.-O., 2014. River stingrays (Chondrichthyes: Potamotrygonidae) from the middle Eocene of Peruvian Amazonia and an overview of potamotrygonid dental morphology. Naturwissenschaften 101, 33-45.

Alberdi Alonso, M.T., Prado, J.L., Salas, R., 2004. The Pleistocene Gomphotheriidae (Proboscidea) from Peru. Neues Jahrbuch für Geologie und Paläontologie Abhandlungen 231, 423-452.

Albert, J.S., Reis, R.E., 2011. Historical Biogeography Of Neotropical Freshwater Fishes. University of California Press, Berkeley.

Anthony, H.E., 1924. A new fossil perissodactyl from Peru. American Museum Novitates $111,1-4$.

Antoine, P.-O., De Franceschi, D., Flynn, J.J., Nel, A., Baby, P., Benammi, M., Calderón, Y., Espurt, N., Goswami, A., Salas-Gismondi, R., 2006. Amber from Western Amazonia reveals Neotropical diversity during the middle Miocene. Proceedings of the National Academy of Sciences of the United States of America 103, 13595-13600.

Antoine, P.-O., Baby, P., Benammi, M., Brusset, S., De Franceschi, D., Espurt, N., Goillot, C., Pujos, F., Salas-Gismondi, R. Tejada, J., Urbina, M., 2007. The Laventan Fitzcarrald local fauna, Amazonian Peru. 4th European Meeting on Paleontology and Stratigraphy of Latin America. Cuadernos del Museo Geominero, Madrid 8, pp. 19-24.

Antoine, P-O Marivaux, L Croft, D. A, Billet, G Ganerød, M., Jaramillo, C, Martin, T, Orliac, M.J., Tejada, J., Duranthon, F., Fanjat, G., Rousse, S., Salas-Gismondi, R., 2012. Middle Eocene rodents from Peruvian Amazonia reveal the pattern and timing of caviomorph origins and biogeography. Proceedings of the Royal Society B: Biology 279, 1319-1326.

Antoine, P.-O., Roddaz, M., Brichau, S., Louterbach, M., Salas Gismondi, R., Altamirano, A., Tejada, J., Lambs, L., Otto, T., Brusset, S., 2013. Middle Miocene vertebrates from the Amazonian Madre de Dios Subandean Zone, Perú. Journal of South American Earth Sciences 42, 91-102.

Antoine, P.-O., Billet, G., Salas-Gismondi, R., Tejada Lara, J., Baby, P., Brusset, S., Espurt, N., 2015. A new Carodnia Simpson, 1935 (Mammalia, Xenungulata) from the early Eocene of Northwestern Peru and a phylogeny of xenungulates at species level. Journal of Mammalian Evolution 22, 129-140.

Archer, M., Arena, R., Bassarova, M., Black, K., Brammall, J., Cooke, B., Creaser, P., Crosby, K., Gillespie, A., Godthelp, H., Gott, M., Hand, S.J., Kear, B., Krikmann, A., Mackness, B., Muirhead, J., Musser, A., Myers, T., Pledge, N., Wang, Y., Wroe, S., 1999. The evolutionary history and diversity of Australian mammals. Australian Mammalogy 21, 1-45.

Armijo, R., Lacassin, R., Coudurier-Curveur, A., Carrizo, D., 2015. Coupled tectonic evolution of Andean orogeny and global climate. Earth-Science Reviews 143, 1-35.

Arnal, M., Kramarz, A.G., Vucetich, M.G., Vieytes, E.C., 2014. A new early Miocene octodontoid rodent (Hystricognathi, Caviomorpha) from Patagonia (Argentina) and a reassessment of the early evolution of Octodontoidea. Journal of Vertebrate Paleontology 34, 397-406.

Bacon, C.D., Silvestro, D., Jaramillo, C.A., Smith, B.T., Chakrabarty, P., Antonelli, A., 2015. Biological Evidence Supports an Early and Complex Emergence of the Isthmus of Panama. Proceedings of the National Academy of Sciences of the United States of America 112, 6110-6115.

Barbosa-Rodrigues, J., 1892. Les Reptiles fossiles de la vallée de l'Amazone. Vellosia 2, $41-46$.

Bayona, G., Cortés, M., Jaramillo, C., Ojeda, G., Aristizabal, J., Reyes-Harker, A., 2008. An integrated analysis of an orogen-sedimentary basin pair: Latest Cretaceous-Cenozoic evolution of the linked Eastern Cordillera orogen and the Llanos foreland basin of Colombia. Geological Society of America Bulletin 120, 1171-1197.

Bayona, G., Montes, C., Cardona, A., Jaramillo, C., Ojeda, G., Valencia, V., 2011. Intraplate subsidence and basin filling adjacent to an oceanic arc-continent collision: a case from the southern Caribbean-South America plate margin. Basin Research 23, 403-422.

Beck, R.M., 2012. An 'ameridelphian'marsupial from the early Eocene of Australia supports a complex model of Southern Hemisphere marsupial biogeography. Naturwissenschaften 99, 715-729.

Billet, G., 2010. New observations on the skull of Pyrotherium (Pyrotheria, Mammalia) and new phylogenetic hypotheses on South American ungulates. Journal of Mammalian Evolution 17, 21-59.

Bond, M., López, G., Reguero, M.A., Scillato-Yané, G.J., Vucetich, M.G., 1998. Los Mamíferos de la Formación Fray Bentos (Edad Mamífero Deseadense, Oligoceno Superior?) de las Provincias de Corrientes y entre Río, Argentina. Asociación Paleontológica Argentina, Publicación Especial 5 pp. 41-50. 
Bond, M., Tejedor, M.F., Campbell Jr., K.E., Chornogubsky, L., Novo, N., Goin, F., 2015. Eocene primates of South America and the African origins of New World monkeys. Nature 520, 538-541.

Boonstra, M., Troelstra, S.R., Lammertsma, E.I., Ramos, M.I.F., Antoine, P.-O., Hoorn, C., 2015. Marine connections of Amazonia: Evidence from foraminifera and dinoflagellate cysts (early to middle Miocene, Colombia/Peru). Palaeogeography, Palaeoclimatology, Palaeoecology 417, 176-194.

Brito, P.M., Deynat, P.P., 2004. Freshwater stingrays from the Miocene of South America with comments on the rise of potamotrygonids (Batoidea, Myliobatiformes). In: Arratia, G., Wilson, M.V.H., Cloutier, R. (Eds.), Recent advances in the origin and early radiation of vertebrates. Dr. Friedrich Pfeil, Munich, pp. 575-582.

Brito, P.M., Meunier, F.J., Leal, M.E.C., 2007. Origine et diversification de l'ichtyofaune néotropicale: une revue. Cybium 31, 1-15.

Buckley, M., 2015. Ancient collagen reveals evolutionary history of the endemic South American 'ungulates'. Proceedings of the Royal Society B 282. http://dx.doi.org/10. 1098/rspb.2014.2671.

Buffetaut, E., Hoffstetter, R., 1977. Découverte du Crocodilien Sebecus dans le Miocène du Pérou oriental. Comptes Rendus de l'Académie des Sciences, Paris 284, 1663-1666.

Cadena, E.A., 2014. The fossil record of turtles in Colombia; a review of the discoveries, research and future challenges. Acta Biológica Colombiana 19, 333-339.

Cadena, E.A., Bloch, J.I., Jaramillo, C.A., 2010. New podocnemidid Turtle (Testudines: Pleurodira) from the Middle-Upper Paleocene of South America. Journal of Vertebrate Paleontology 30, 367-382.

Calderón-Patrón, J.M., Moreno, C.E., Pineda-López, R., Sánchez-Rojas, G., Zuria, I., 2013. Vertebrate dissimilarity due to turnover and richness differences in a highly betadiverse region: the role of spatial grain size, dispersal ability and distance. PLoS ONE 8 (12), e82905.

Campbell, K.E., 2004. Paleogene mammalian fauna of Santa Rosa, Amazonian Peru. Natural History Museum of Los Angeles County Science Series 40 (Los Angeles).

Campbell, K.E., Frailey, C.D., Romero Pittman, L., 2000. The Late Miocene Gomphothere Amahuacatherium peruvium (Proboscidea: Gomphotheriidae) From Amazonian Peru: Implications for the Great American Faunal Interchange. Boletín del INGEMMET, Lima.

Campbell, K.E., Heizler, M., Frailey, C.D., Romero-Pittman, L., Prothero, D.R., 2001. Upper Cenozoic chronostratigraphy of the southwestern Amazon Basin. Geology 297, 595-598.

Campbell, K.E., Prothero, D.R., Romero-Pittman, L., Hertel, F., Rivera, N., 2010. Amazonian magnetostratigraphy: dating the first pulse of the Great American Faunal Interchange. Journal of South American Earth Sciences 29, 619-626.

Cardona, A., Ruiz, J., Valencia, V., Bayona, G., Duque, J., Jaramillo, C., Montes, C., Ojeda, G., 2010. Turonian to Eocene accretion and subduction in the Santa Marta massif and Rancheria Basin, Colombia: Implications for Northern Andean Orogeny. Terra Nova 23, 26-34.

Carrillo, J.D., Forasiepi, A., Jaramillo, C., Sánchez-Villagra, M.R., 2014. Neotropical mammal diversity and the Great American Biotic Interchange: spatial and temporal variation in South America's fossil record. Frontiers in Genetics http://dx.doi.org/10.3389/ fgene.2014.00451.

Carvajal-Ortiz, H., Mora, G., Jaramillo, C., 2009. Molecular biomarker evaluation of a terrestrial carbon isotope record as a chronostratigraphic tool for the Paleocene-Eocene of tropical sequences. Palaeogeography, Palaeoclimatology, Palaeoecology 277, 173-183.

Chassagne-Manoukian, M., Haddoumi, H., Cappetta, H., Charrière, A., Feist, M., Tabuce, R., Vianey-Liaud, M., 2013. Dating the "red beds" of the Eastern Moroccan High Plateaus: Evidence from late Late Cretaceous charophytes and dinosaur eggshells. Geobios 46 371-379.

Christophoul, F., Baby, P., Dávila, C., 2002. Stratigraphic responses to a major tectonic event in a foreland basin: the Ecuadorian Oriente Basin from Eocene to Oligocene times. Tectonophysics 345, 281-298.

Ciancio, M.R., Carlini, A.A., Campbell, K.E., Scillato-Yané, G.J., 2013. New Palaeogene cingulates (Mammalia, Xenarthra) from Santa Rosa, Perú and their importance in the context of South American faunas. Journal of Systematic Palaeontology 11, 727-741.

Colin, J.-P., Antunes, M.T., 2003. Limnic ostracoda from Silveirinha, Portugal (?Late Paleocene-Lowermost Eocene). Ciências da Terra 15, 91-100.

Corfu, F., 2004. U-Pb Age, Setting and Tectonic Significance of the Anorthosite-MangeriteCharnockite-Granite Suite, Lofoten-Vesterålen, Norway. Journal of Petrology 45, 1799-1819.

Cozzuol, M.A., 2006. The Acre vertebrate fauna: age, diversity, and geography. Journal of South American Earth Sciences 21, 185-203.

Croft, D.A., Flynn, J.J., Wyss, A.R., 2007. A new basal glyptodontid and other Xenarthra of the early Miocene Chucal Fauna, northern Chile. Journal of Vertebrate Paleontology 27, 781-797.

Croft, D.A., Anaya, F., Auerbach, D., Garzione, C., MacFadden, B.J., 2009. New data on Miocene Neotropical provinciality from Cerdas, Bolivia. Journal of Mammalian Evolution $16,175-198$

Czaplewski, N.J., Campbell, K.E., 2004. A possible bat (Mammalia: Chiroptera) from the? Eocene of Amazonian Peru. In: Campbell, K.E. (Ed.), The Paleogene Mammalian Fauna of Santa Rosa, Amazonian PeruScience Series 40. Natural History Museum of Los Angeles County, Los Angeles, pp. 141-144.

Czaplewski, N.J., Masanaru, T., Naeher, T.M., Shigehara, N., T. Setoguchi T., 2003. Additional bats from the middle Miocene La Venta fauna of Colombia. Revista de la Academia Colombiana de Ciencias 27, 263-282.

Domning, D.P., 1982. Evolution of the manatees: a speculative history. Journal of Paleontology 56, 599-619.

Domning, D.P., 2005. Fossil Sirenia of the West Atlantic and Caribbean region. VII. Pleistocene Trichechus manatus Linnaeus, 1758. Journal of Vertebrate Paleontology 25, 685-701.
Doria, G., Jaramillo, C.A., Herrera, F., 2008. Menispermaceae from the Cerrejón Formation, middle to late Paleocene, Colombia. American Journal of Botany 95, 954-973.

Dos Santos, J., Rancy, A., Ferigolo, J., 1993. Octodontobradyinae, uma nova subfamília de Orophontidae (Edentata, Tardigrada) do Mioceno Superior-Plioceno do Estado do Amazonas, Brasil. Ameghiniana 30, 255-264.

Espurt, N., Baby, P., Brusset, S., Roddaz, M., Hermoza, W., Regard, V., Antoine, P.-O., SalasGismondi, R., Bolaños, R., 2007. How does the Nazca Ridge subduction influence the modern Amazonian foreland basin? Geology 35, 515-518.

Espurt, N., Baby, P., Brusset, S., Roddaz, M., Hermoza, W., Barbarand, J., 2010. The Nazca Ridge and uplift of the Fitzcarrald Arch: implications for regional geology in northern South America. In: Hoorn, C., Wesselingh, F.P. (Eds.), Amazonia, Landscape and Species Evolution: A Look into the Past. Blackwell-Wiley, pp. 89-100.

Espurt, N., Barbarand, J., Roddaz, M., Brusset, S., Baby, P., Saillard, M., Hermoza, W., 2011. A scenario for late Neogene Andean shortening transfer in the Camisea Subandean zone (Peru, $12^{\circ} \mathrm{S}$ ): Implications for growth of the northern Andean Plateau. Geological Society of America Bulletin 123, 2050-2068.

Eude, A., Roddaz, M., Brichau, S., Brusset, S., Baby, P., Calderón, Y., Soula, J.-C., 2015. Controls on timing of exhumation and deformation in the Northern Peruvian Eastern Andean wedge as inferred from Low-Temperature Thermochronology and Balanced Cross-Section. Tectonics 34. http://dx.doi.org/10.1002/2014TC003641.

Feist, M., Brouwers, E., 1990. A New Tolypella from the Ocean Point Dinosaur Locality North Slope, Alaska, and the Late Cretaceous to Paleocene Nitelloid Charophytes. US Geological Survey Bulletin 1, 1-16.

Ferretti, M.P., 2008. A review of South American proboscideans. Neogene Mammals. New Mexico Museum of Natural History and Science Bulletin 44, 381-392.

Flynn, J.J., Wyss, A.R., Croft, D.A., Charrier, R., 2003. The Tinguiririca Fauna, Chile: biochronology, paleoecology, biogeography, and a new earliest Oligocene South American Land Mammal 'Age'. Palaeogeography, Palaeoclimatology, Palaeoecology $195,229-259$.

Flynn, J.J., Charrier, R., Croft, D.A., Wyss, A.R., 2012. Cenozoic Andean faunas: shedding new light on South American mammal evolution, biogeography, environments, and tectonics. In: Patterson, B.D., Costa, L.P. (Eds.), Bones, Clones, and Biomes: The History and Geography of Recent Neotropical Mammals. university of Chicago Press, pp. 51-75.

Frailey, C.D., 1986. Late Miocene and Holocene mammals, exclusive of the Notoungulata, of the Rio Acre region, western Amazonia. Natural History Museum of Los Angeles County Contributions in Science 374 pp. 1-46.

Frailey, C.D., Campbell, K.E., 2004. Paleogene rodents from Amazonian Peru: the Santa Rosa local fauna. In: Campbell, K.E. (Ed.), The Paleogene Mammalian Fauna of Santa Rosa, amazonian Peru. Natural History Museum of Los Angeles County Science Series 40, pp. 71-130.

Gabb, W.M., 1869. Descriptions of fossils from the clay deposits of the Upper Amazon. American Journal of Conchology 4, 197-200.

Gaudin, T.J., Croft, D.A., 2015. Paleogene Xenarthra and the evolution of South American mammals. Journal of Mammalogy 96, 622-634.

Gayet, M., Rage, J.-C., Sempéré, T., Gagnier, P.-Y., 1992. Modalités des échanges de vertébrés continentaux entre l'Amérique du Nord et l'Amérique du Sud au Crétacé supérieur et au Paléocène. Bulletin de la Societe Geologique de France 163, 781-791.

Gayet, M., Jégu, M., Bocquentin, J., Negri, F.R., 2003. New characoids from the Upper Cretaceous and Paleocene of Bolivia and the Mio-Pliocene of Brazil: phylogenetic position and paleobiogeographic implications. Journal of Vertebrate Paleontology 23, 28-46.

Germeraad, J.H., Hopping, C.A., Muller, J., 1968. Palynology of Tertiary sediments from tropical areas. Review of Palaeobotany and Palynology 6, 189-348.

Gil, W., Baby, P., Ballard, J.F., 2001. Structure et contrôle paléogéographique de la zone subandine péruvienne. Comptes Rendus de l'Académie des Sciences-Sciences de la Terre et des Planètes 333, 741-748.

Goillot, C., Antoine, P.-O., Tejada Lara, J., Pujos, F., Salas-Gismondi, R., 2011. Middle Miocene Uruguaytheriinae (Mammalia, Astrapotheria) from Peruvian Amazonia and a review of the astrapotheriid fossil record in northern South America. Geodiversitas 33, 331-345.

Goin, F.J., Candela, A.M., 2004. New Paleogene marsupials from the Amazon Basin of eastern Peru. In: Campbell, K.E. (Ed.), The Paleogene Mammalian Fauna of Santa Rosa, Amazonian Peru. Natural History Museum of Los Angeles County Science Series 40, pp. 15-60.

Goin, F.J., Case, J.A., Woodburne, M.O., Vizcaíno, S.F., Reguero, M.A., 1999. New discoveries of "opossum-like" marsupials from Antarctica (Seymour Island, Medial Eocene). Journal of Mammalian Evolution 6, 335-365.

Goin, F.J., Vieytes, E.C., Vucetich, M.G., Carlini, A.A., Bond, M., 2004. Enigmatic mamma from the Paleogene of Perú. In: Campbell, K.E. (Ed.), The Paleogene Mammalian Fauna of Santa Rosa, Amazonian Peru. Natural History Museum of Los Angeles County Science Series 40, pp. 145-153.

Goin, F.J., Zimicz, N., Reguero, M.A., Santillana, S.N., Marenssi, S.A., Moly, J.J., 2007. Nuevo marsupial (Mammalia) del Eoceno de la Antártida, y los orígenes y afinidades de los Microbiotheria. Revista de la Asociación Geológica Argentina 62, 597-603.

Gross, M., Ramos, M.I., Caporaletti, M., Piller, W.E., 2013. Ostracods (Crustacea) and their palaeoenvironmental implication for the Solimões Formation (Late Miocene; Western Amazonia/Brazil). Journal of South American Earth Sciences 42, 216-241.

Gross, M., Ramos, M.I.F., Piller, W.E., 2014. On the Miocene Cyprideis species flock (Ostracoda; Crustacea) of Western Amazonia (Solimões Formation): Refining taxonomy on species level. Zootaxa 3899, 1-69.

Hastings, A.K., Bloch, J.I., Cadena, E.A., Jaramillo, C.A., 2010. A New Small Short Snouted Dyrosaurid (Crocodylomorpha, Mesoeucrocodylia) from the Paleocene of Northeastern Colombia. Journal of Vertebrate Paleontology 30, 139-162.

Hastings, A.K., Bloch, J.I., Jaramillo, C.A., 2011. A New Longirostrine Dyrosaurid (Crocodylomorpha, Mesoeucrocodylia) from the Paleocene of Northeastern 
Colombia: Biogeographic and Behavioural Implications for New World Dyrosauridae. Palaeontology 54, 1095-1116.

Head, J.J., Bloch, J.I., Hastings, A.K., Bourque, J., Cadena, E.A., Herrera, F.A., Polly, P.D., Jaramillo, C.A., 2009. Giant boid snake from the Palaeocene Neotropics reveals hotter past equatorial temperatures. Nature 457, 715-716.

Hendy, A.J.W., Jones, D.S., Moreno, F., Zapata, V., Jaramillo, C., 2015. Neogene molluscs, shallow-marine paleoenvironments and chronostratigraphy of the Guajira Peninsula, Colombia. Swiss Journal of Palaeontology http://dx.doi.org/10.1007/s13358-0150074-1.

Hermoza, W., Brusset, S., Baby, P., Gil, W., Roddaz, M., Guerrero, N., Bolaños, R., 2005. The Huallaga foreland basin evolution: Thrust propagation in a deltaic environment, northern Peruvian Andes. Journal of South American Earth Sciences 19, 21-34.

Herrera, F.A., Jaramillo, C.A., Dilcher, D.L., Wing, S.L., Gómez, N.C., 2008. Fossil Araceae from a Paleocene Neotropical rainforest in Colombia. American Journal of Botany 95, 1569-1583.

Hirschfeld, S.E., Marshall, L.G., 1976. Revised faunal list of the La Venta fauna (FriasianMiocene) of Colombia, South America. Journal of Paleontology 50, 433-436.

Hoorn, C., 1993. Marine incursions and the influence of Andean tectonics on the Miocene depositional history of northwestern Amazonia: results of a palynostratigraphic study. Palaeogeography, Palaeoclimatology, Palaeoecology 105, 267-309.

Hoorn, C., 1994. An environmental reconstruction of the palaeo-Amazon river system (Middle-Late Miocene, NW Amazonia). Palaeogeography, Palaeoclimatology, Palaeoecology 112, 187-238.

Hoorn, C., Wesselingh, F., 2010. Amazonia, Landscape and Species Evolution: A Look into the Past. John Wiley \& Sons, Hoboken.

Hoorn, C., Wesselingh, F.P., Ter Steege, H., Bermudez, M.A., Mora, A., Sevink, J., Sanmartín, I., Sanchez-Meseguer, A., Anderson, C.L., Figueiredo, J.P., Jaramillo, C., Riff, D., Negri, F.R., Hooghiemstra, H., Lundberg, J., Stadler, T., Särkinen, T., Antonelli, A., 2010a. Amazonia through time: Andean uplift, climate change, landscape evolution, and biodiversity. Science 330, 927-931.

Hoorn, C., Wesselingh, F.P., Hovikoski, J., Guerrero, J., 2010b. The development of the Amazonian Mega-Wetland (Miocene; Brazil, Colombia, Peru, Bolivia). In: Hoorn, $\mathrm{C}$. Wesselingh, F.P. (Eds.), Amazonia, Landscape and Species Evolution: A Look into the Past. Blackwell-Wiley, Hoboken, pp. 123-142.

Hovikoski, J., Wesselingh, F.P., Räsänen, M., Gingras, M., Vonhof, H.B., 2010. Marine influence in Amazonia: evidence from the geological record. In: Hoorn, C. Wesselingh, F.P. (Eds.), Amazonia, Landscape and Species Evolution: A Look into the Past. BlackwellWiley, Hoboken, pp. 143-160.

Hulka, C., Gräfe, K.-U., Sames, B., Uba, C.E., Heubeck, C., 2006. Depositional setting of the Middle to Late Miocene Yecua Formation of the Chaco Foreland Basin, southern Bolivia. Journal of South American Earth Sciences 21, 135-150.

Jaffey, A.H., Flynn, K.F., Glendenin, L.E., Bentley, W.C., Essling, A.M., 1971. Precision measurement of half-lives and specific activities of ${ }^{235} \mathrm{U}$ and ${ }^{238} \mathrm{U}$. Physical Review C: Nuclear Physics 4, 1889-1906.

Jaillard, E., Carlotto, V., Cardenas, J., Chavez, R., Gil, W., 1993. La "Nappe des Couches Rouges" de Cuzco (Sud du Pérou): mise en évidence stratigraphique, interprétation ectoniques et paléogéographiques. Comptes Rendus de l'Académie des Sciences, Paris 36, 379-386.

Jaillard, E., Feist, M., Grambast-Fessard, N., Carlotto, V., 1994. Senonian-Paleocene charophyte succession of the Peruvian Andes. Cretaceous Research 15, 445-456.

Jaramillo, C.A., Pardo-Trujillo, A., Rueda, M., Harrington, G., Bayona, G., Torres, V., Mora, G. 2007. The Palynology of the Cerrejón Formation (Upper Paleocene), Northern Colombia. Palynology 31, 153-189.

Jaramillo, C., Rueda, M., Bayona, G., Santos, C., Florez, P., Parra, F., 2009. Biostratigraphy breaking paradigms: dating the Mirador Formation in the Llanos Basin of Colombia. In: Demchuk, T., Waszczak, R. (Eds.), Geological Problem Solving with Microfossils: A Volume in Honor of Garry D. JonesSpecial Publication 93. SEPM, Tulsa, pp. 29-40.

Jaramillo, C., Rueda, M., Torres, V., 2011. A Palynological Zonation for the Cenozoic of the Llanos Foothills of Colombia. Palynology 35, 46-84.

Jaramillo, C., Moreno, F., Hendy, F., Sánchez-Villagra, M., Marty, D., 2015. Preface: La Guajira, Colombia: a new window into the Cenozoic neotropical biodiversity and the Great American Biotic Interchange. Swiss Journal of Palaeontology http://dx.doi. org $10.1007 / \mathrm{s} 13358-015-0075-0$

Kay, R.F., 2015. New World monkey origins. Science 347, 1067-1068.

Kay, R.F., Cozzuol, M.A., 2006. New platyrrhine monkeys from the Solimões formation (late Miocene, Acre State, Brazil). Journal of Human Evolution 50, 673-686.

Kay, R.F., Frailey, C.D., 1993. Large fossil platyrrhines from the Rio Acre local fauna, late Miocene, western Amazonia. Journal of Human Evolution 25, 319-327.

Kay, R.F., Madden, R.H., 1997. Paleogeography and paleoecology. In: Kay, R.F., Madden, R.H., Cifelli, R.L., Flynn, J.J. (Eds.), Vertebrate Paleontology in the Neotropics: The Miocene Fauna of La Venta, Colombia. Smithsonian Institution Press, Washington D.C pp. 520-550.

Kerber, L., Negri, F.R., Ribeiro, A.M., Vucetich, M.G., De Souza-Filho, J.P., 2015. Late Miocene potamarchine rodents from southwestern Amazonia, Brazil, with description of new taxa. Acta Palaeontologica Polonica http://dx.doi.org/10.4202/app.00091.2014.

Klaus, S., Yeo, D.C.J., Ahyong, S.T., 2011. Freshwater crab origins-laying Gondwana to rest. Zoologischer Anzeiger 250, 449-456.

Kramarz, A., 2006. Neoreomys and Scleromys (Rodentia, Hystricognathi) from the Pinturas Formation, late Early Miocene of Patagonia, Argentina. Revista del Museo Argentino de Ciencias Naturales 8, 53-62.

Kramarz, A.G., Bond, M., Forasiepi, A.M., 2011. New remains of Astraponotus (Mammalia, Astrapotheria) and considerations on astrapothere cranial evolution. Paläontologische Zeitschrift 85, 185-200

Kummel, B., 1948. Geological reconnaissance of Contamana region, Peru. Geological Society of America Bulletin 59, 1217-1266.
Linhares, A.P., Ramos, M.IF., Gross, M., Piller, W.E, 2011. Evidence for marine influx during the Miocene in southwestern Amazonia, Brazil. Geologia Colombiana 36, 91-104.

Lipa, V., Larico, W., Cuyubamba, V., 1997. Geología de los cuadrángulos de Puerto Oriente, Ana María y Rio Tapiche. Boletín del INGEMMET 101.

Lorente, M., 1986. Palynology and Palynofacies of the Upper Tertiary in Venezuela. J. Cramer, Berlin.

Louterbach, M., Roddaz, M., Bailleul, J., Antoine, P.-O., Adnet, S., Kim, J.H., van Soelen, E., Parra, F., Gérard, J., Calderon, Y., Gagnaison, C., Sinninghe Damsté, J.S., Baby, P., 2014. Evidences for a Paleocene marine incursion in Southern Amazonia (Madre de Dios Sub-Andean Zone, Peru). Palaeogeography, Palaeoclimatology, Palaeoecology 414, 451-471.

Lovejoy, N.R., Bermingham, E., Martin, A.P., 1998. Marine incursion into South America. Nature 396, 421-422.

Lovejoy, N.R., Albert, J.S., Crampton, W.G., 2006. Miocene marine incursions and marine/ freshwater transitions: Evidence from Neotropical fishes. Journal of South American Earth Sciences 21, 5-13.

Lundberg, J.G., 1997. Fishes of the Miocene La Venta fauna: additional taxa, biotic and paleoenvironmental implications. In: Kay, R.F., Madden, R.H., Cifelli, R.L., Flynn, J.J. (Eds.), Vertebrate paleontology in the Neotropics: The Miocene fauna of La Venta, Colombia. Smithsonian Institution Press, Washington DC, pp. 67-91.

Lundberg, J.G., Marshall, L.G., Guerrero, J., Horton, B., Malabarba, M.C., Wesselingh, F., 1998. The stage for Neotropical fish diversification: a history of tropical South American rivers. In: Malabarba, L.R., Reis, R.E., Vari, R.P., Lucena, Z.M.S., Lucena, C.A.S. (Eds.), Phylogeny and Classification of Neotropical Fishes. EDIPUCRS, Porto Alegre, pp. $13-48$

Lundberg, J.G., Sabaj Pérez, M.H., Dahdul, W.M., Aguilera, O.A., 2010. The Amazonian Neogene fish fauna. In: Hoorn, C., Wesselingh, F.P. (Eds.), Amazonia, Landscape and Species Evolution: A Look into the Past. Blackwell-Wiley, Hoboken, pp. 281-301.

MacFadden, B.J., 1990. Chronology of Cenozoic primate localities in South America. Journal of Human Evolution 19, 7-21.

MacFadden, B.J., 2006. Extinct mammalian biodiversity of the ancient New World tropics. Trends in Ecology \& Evolution 21, 157-165.

Madden, R.H., Guerrero, J., Kay, R.F., Flynn, J.J., Swisher III, C.C., Walton, A.H., 1997. The Laventan Stage and Age. In: Kay, R.F. Madden, R.H., Cifelli, R.L, Flynn, J. (Eds.), Vertebrate Paleontology in the Neotropics: The Miocene Fauna of La Venta, Colombia. Smithsonian Institution Press, Washington DC, pp. 499-519.

Marivaux, L., Salas-Gismondi, R., Tejada, J., Billet, G., Louterbach, M., Vink, J., Bailleul, J., Roddaz, M., Antoine, P.-O., 2012. A platyrrhine talus from the early Miocene of Peru (Amazonian Madre de Dios Sub-Andean Zone). Journal of Human Evolution 63, 696-703.

Marocco, R., Valdez Pardo, A.M., Rivadeneira, M., 1996. Sedimentología de las formaciones de edad eocena y oligocena de la Cuenca Orienta. IRD-Petroproducción, Lima.

Martín-Closas, C., Guerrero, E.R., 2005. Palaeogene Charophytes of the Balearic Islands (Spain). Geologica Acta 3, 39-58.

Mattinson, J.M., 2005. Zircon U-Pb chemical abrasion ("CA-TIMS") method: Combined annealing and multi-step partial dissolution analysis for improved precision and accuracy of zircon ages. Chemical Geology 220, 47-66.

Mebrouk, F., Tabuce, R., Cappetta, H., Feist, M., 2009. Charophytes du Crétacé/Paléocène du Moyen-Atlas (Maroc): systématique et implications biochronologiques. Revue de Micropaleontologie 52, 131-139.

Monsch, K.A., 1998. Miocene fish faunas from the northwestern Amazonia basin (Colombia, Peru, Brazil) with evidence of marine incursions. Palaeogeography, Palaeoclimatology, Palaeoecology 143, 31-50.

Montes, C., Cardona, A., Jaramillo, C., Pardo, A., Silva, J.C., Valencia, V., Ayala, C., PérezAngel, L.C., Rodriguez-Parra, L.A., Ramirez, V., Niño, H., 2015. Middle Miocene closure of the Central American Seaway. Science 348, 226-229.

Mora, A., Baby, P., Roddaz, M., Parra, M., Brusset, S., Hermoza, W., Espurt, N., 2010. Tectonic history of the Andes and sub-Andean zones: implications for the development of the Amazon drainage basin. In: Hoorn, C. Wesselingh, F.P. (Eds.). Amazonia, Landscape and Species Evolution: A Look into the Past. Blackwell-Wiley, Hoboken, pp. 38-60.

Moreno, F., Hendy, A.J.W., Quiroz, L., Hoyos, N., Jones, D.S., Zapata, V., Zapata, S., Ballen, G., Cadena, E., Cárdenas, A.L., Carrillo-Briceño, J.D., Carrillo, J.D., Delgado-Sierra, D., Escobar, J., Martinez, J.I., Martinez, C., Montes, C., Moreno, J., Perez, N., Sanchez, R., Suarez, C., Vallejo-Pareja, M.C., Jaramillo, C., 2015. Revised stratigraphy of Neogene strata in the Cocinetas basin, La Guajira, Colombia. Swiss Journal of Palaeontology http://dx.doi.org/10.1007/s13358-015-0071-4

Mothé, D., Avilla, L., 2015. Mythbusting evolutionary issues on South American Gomphotheriidae (Mammalia: Proboscidea). Quaternary Science Reviews 110, 23-35.

Mourier, T. Bengtson, P. Bonhomme, M., Buge, E Cappetta, H., Crochet, J.-Y, Feist, M. Hirsch, K.F., Jaillard, E., Lefranc, J.-P., Moullade, M., Noblet, C., Pons, D., Rey, J., Sigé, B., Tambareau, Y., Taquet, P., 1988. The Upper Cretaceous-Lower Tertiary marine to continental transition in the Bagua basin, northern Perú. Newsletters on Stratigraphy 19,143-177.

Muller, J., Di Giacomo, E., Van Erve, A., 1987. A palynologic zonation for the Cretaceous, Tertiary and Quaternary of Northern South America. American Association of Stratigraphic Palynologists Contribution Series 19 pp. 7-76.

Muñoz-Torres, F., Whatley, R., Van Harten, D., 1998. The endemic non-marine Miocene ostracod fauna of the Upper Amazon Basin. Revista Española de Micropaleontología 30, 89-105

Muñoz-Torres, F.A., Whatley, R.C., Van Harten, D., 2006. Miocene ostracod (Crustacea) biostratigraphy of the upper Amazon Basin and evolution of the genus Cyprideis. Journal of South American Earth Sciences 21, 75-86.

Musacchio, E.A., 1973. Charophytas y ostrácodos no marinos del Grupo Neuquén (Cretácico Superior) en algunos afloramientos de las provincias de Río Negro y Neuquén en la República Argentina. Revista Museo de La Plata, Paleontología 8, 1-33. 
Musacchio, E.A., 2006. Charophyta del Cretácico Tardío y el Paleoceno del centro oeste de Argentina. Revista Brasileira de Paleontología 9, 93-100.

Musacchio, E.A., 2010. Upper Cretaceous Lychnothamnus, Nitella and Tolypella (Charophyta) from Zampal, Argentina. Cretaceous Research 31, 461-472.

Naeser, C.W., Crochet, J.-Y., Jaillard, E., Laubacher, G., Mourier, T., Sigé, B., 1991. Tertiary fission-track ages from the Bagua syncline (northern Peru): stratigraphic and tectonic implications. Journal of South American Earth Sciences 4, 61-71.

Negri, F.R., Bocquentin Villanueva, J., Ferigolo, J., Antoine, P.-O., 2010. 16. A review of Tertiary mammal faunas and birds from western Amazonia. In: Hoorn, C., Wesselingh, F.P. (Eds.), Amazonia, Landscape and Species Evolution: A Look into the Past. Blackwell-Wiley, Hoboken, pp. 245-258.

Olivier, J., Otto, T., Roddaz, M., Antoine, P.-O., Londoño, X., Clark, L.G., 2009. First macrofossil evidence of a pre-Holocene thorny bamboo cf. Guadua (Poaceae: Bambusoideae: Bambuseae: Guaduinae) in south-western Amazonia (Madre de Dios - Peru). Review of Palaeobotany and Palynology 153, 1-7.

Oppenheim, V., 1937. Contribución a la geología de los Andes venezolanos. Boletín Geológico y Minero 1, 11-13.

Patterson, B., 1942. Two Tertiary mammals from northern South America. American Museum Novitates 1173, 1-8.

Paula-Couto, C.D., 1956. Mamíferos fósseis do Cenozóico da Amazônia. Instituto Brasileiro de Bibliografia e Documentação, Rio de Janeiro Boletim 3 pp. 1-121.

Pérez, M.E., Pol, D., 2012. Major radiations in the evolution of caviid rodents: reconciling fossils, ghost lineages, and relaxed molecular clocks. PLoS ONE, e48380.

Perrichot, V., Antoine, P.-O., Salas-Gismondi, R., Flynn, J.J., Engel, M.S., 2014. The genus Macroteleia Westwood in mid-Miocene amber from Peru (Hymenoptera: Platygastridae s. l.: Scelioninae). Zookeys 426, 119-127.

Petrulevičius, J.F., Nel, A., De Franceschi, D., Goillot, C., Antoine, P.-O., Salas-Gismondi, R., Flynn, J.J., 2011. First fossil blood sucking Psychodidae in South America: a sycoracinae (Insecta: Diptera) in the middle Miocene Amazonian amber. Insect Systematics \& Evolution 42, 87-96.

Pol, D., Powell, J.E., 2011. A new sebecid mesoeucrocodylian from the Rio Loro Formation (Palaeocene) of north-western Argentina. Zoological Journal of the Linnean Society $163,7-36$.

Pujos, F., Albino, A.M., Baby, P., Guyot, J.-L., 2009. Presence of the extinct lizard Paradracaena (Teiidae) in the middle Miocene of the Peruvian Amazon. Journal of Vertebrate Paleontology 29, 594-598.

Pujos, F., Salas-Gismondi, R., Baby, G., Baby, P., Goillot, C., Tejada, J., Antoine, P.-O., 2013. Implication of the presence of Megathericulus (Xenarthra: Tardigrada: Megatheriidae) in the Laventan of Peruvian Amazonia. Journal of Systematic Palaeontology 11, 973-991.

Rage, J.-C., Pickford, M., Senut, B., 2013. Amphibians and squamates from the middle Eocene of Namibia, with comments on pre-Miocene anurans from Africa. Annales de Paleontologie 99, 217-242.

Ramos, M.I.F., 2006. Ostracods from the Neogene Solimões Formation (Amazonas, Brazil). Journal of South American Earth Sciences 21, 87-95.

Ravel, A., Marivaux, L., Qi, T., Wang, Y.Q., Beard, K.C., 2014. New chiropterans from the middle Eocene of Shanghuang (Jiangsu Province, Coastal China): new insight into the dawn horseshoe bats (Rhinolophidae) in Asia. Zoologica Scripta 43, 1-23.

Regali, M., Uesugui, N., Santos, A., 1974. Palinologia dos sedimentos Meso-Cenozoicos do Brasil. Boletim Tecnico da Petrobras 17, 177-191.

Ribeiro, A.M., Madden, R.H., Negri, F.R., Kerber, L., Hsiou, A.S., Rodrigues, K.A., 2013. Mamíferos fósiles y biocronología en el suroeste de la Amazonia, Brasil. In: Brandoni, D., Noriega, J.I. (Eds.), El Neógeno de la Mesopotamia argentina. Asociación Paleontológica Argentina, Publicación Especial 14, pp. 207-221.

Rincón, A.D., Solórzano, A., Benammi, M., Vignaud, P., McDonald, H.G., 2014. Cronología y geología de una asociación de mamíferos del Mioceno Temprano en el Norte de América del Sur, cerro La Cruz (Formación Castillo), Estado Lara, Venezuela: implicaciones para las hipótesis del 'cambio del curso del río Orinoco'. Andean Geology 41, 507-528.

Roddaz, M., Hermoza, W., Mora, A., Baby, P., Parra, M., Christophoul, F., Brusset, S., Espurt, N., 2010. Cenozoic sedimentary evolution of the Amazonian foreland basin system. In: Hoorn, C., Wesselingh, F.P. (Eds.), Amazonia, Landscape and Species Evolution: A Look into the Past. Blackwell-Wiley, Hoboken, pp. 61-88.

Salas-Gismondi, R., Baby, P., Antoine, P.-O., Pujos, F., Benammi, M., Espurt, N., Brusset, S. Urbina, M., De Franceschi, D., 2006. Late middle Miocene vertebrates from the Peruvian Amazonian basin (Inuya and Mapuya Rivers, Ucayali): Fitzcarrald Expedition 2005. XIII Congreso Peruano de Geología, pp. 643-646.

Salas-Gismondi, R., Antoine, P.-O., Baby, P., Benammi, M., Espurt, N., Pujos, F., Tejada, J., Urbina, M., De Franceschi, D., 2007. Middle Miocene crocodiles from the Peruvian Amazonian basin (Fitzcarrald Arch). 4th European Meeting on Paleontology and Stratigraphy of Latin America. Cuadernos del Museo Geominero 8 . pp. 355-360.

Salas-Gismondi, R., Tejada, J., Antoine, P.-O., 2011. Evidence on the tropical history of Paleogene Cingulata. Cuarto Congreso Latinoamericano de Paleontología de Vertebrados.

Salas-Gismondi, R., Flynn, J.J., Baby, P., Antoine, P.-O., 2014. Sobre el origen de la biodiversidad amazónica. In: Varón, R. (Ed.), Iquitos, Ediciones Telefónica, pp. 84-91.

Salas-Gismondi, R., Flynn, J.J., Baby, P., Tejada-Lara, J., Wesselingh, F.P., Antoine, P.-O., 2015. A Miocene hyperdiverse crocodylian community reveals peculiar trophic dynamics in proto-Amazonian mega-wetlands. Proceedings of the Royal Society B http://dx.doi.org/10.1098/rspb.2014.2490.

San Mauro, D., Vences, M., Alcobendas, M., Zardoya, R., Meyer, A., 2005. Initial diversification of living amphibians predated the breakup of Pangaea. The American Naturalist 165, 590-599.

Sánchez-Villagra, M., Scheyer, T., 2010. Fossil turtles from the northern Neotropics: The Urumaco sequence fauna and finds from other localities in Venezuela and Colombia. In: Sánchez-Villagra, M.R., Aguilera, O.A., Carlini, A.A. (Eds.), Urumaco and Venezuelan Paleontology: The Fossil Record of the Northen Neotropics (Life of the Past). Indiana University Press, pp. 173-191.

Sánchez-Villagra, M.R., Burnham, R.J., Campbell, D.C., Feldmann, R.M., Gaffney, E.S., Kay, R.F., Lozsán, R., Purdy, R., Thewissen, J.G.M., 2000. A new near-shore marine fauna and flora from the early Neogene of northwestern Venezuela. Journal of Paleontology 74, 957-968.

Sánchez-Villagra, M., Asher, R.J., Rincón, A.D., Carlini, A.A., Meylan, P., Purdy, R.W., 2004 New faunal reports for the Cerro La Cruz Locality (Lower Miocene, Northwestern Venezuela). In: Sánchez-Villagra, M.R., Clack, J.A. (Eds.), Fossils of the Miocene Castillo Formation, Venezuela: contributions on Neotropical Palaeontology. Special Papers in Palaeontology 71, pp. 105-116.

Sánchez-Villagra, M., Ladevèze, S., Horovitz, I., Argot, C., Hooker, J.J., Macrini, T.E., Martin, T., Moore-Fay, S., de Muizon, C., Schmetzle, T., Asher, R.J., 2007. Exceptionally preserved North American Paleogene metatherians: adaptations and discovery of a major gap in the opossum fossil record. Biology Letters 3, 318-322.

Sanjuan, J., Martín-Closas, C., 2012. Charophyte palaeoecology in the upper Eocene of the Eastern Ebro basin (Catalonia, Spain). Biostratigraphic implications. Palaeogeography, Palaeoclimatology, Palaeoecology 365, 247-262.

Sanjuan, J., Martín-Closas, C., 2014. Taxonomy and palaeobiogeography of charophytes from the Upper Eocene-Lower Oligocene of the Eastern Ebro Basin (Catalonia, NE Spain). Geodiversitas 36, 385-420.

Sheppard, L.M., Bate, R.H., 1980. Plio-Pleistocene ostracods from the upper Amazon of Colombia and Peru. Palaeontology 23, 97-124.

Shockey, B.J., Hitz, R., Bond, M., 2004. Paleogene notoungulates from the Amazon Basin of Peru. In: Campbell, K.E. (Ed.), The Paleogene mammalian fauna of Santa Rosa, Amazonian Peru. Natural History Museum of Los Angeles County Science Series 40, pp. $61-70$

Shockey, B.J., Salas, R., Quispe, R., Flores, A., Sargis, E.J., Acosta, J., Pino, A., Jarica, N.J., Urbina, M., 2006. Discovery of Deseadan fossils in the upper Moquegua Formation (late Oligocene-? early Miocene) of southern Peru. Journal of Vertebrate Paleontology 26, 205-208.

Shockey, B.J., Salas Gismondi, R., Gans, P., Jeong, A., Flynn, J.J., 2009. Paleontology and geochronology of the Deseadan (late Oligocene) of Moquegua, Perú. American Museum Novitates 3668, 1-24.

Sidlauskas, B.L., Vari, R.P., 2008. Phylogenetic relationships within the South American fish family Anostomidae (Teleostei, Ostariophysi, Characiformes). Zoological Journa of the Linnean Society 154, 70-210.

Sigé, B., Archer, M., Crochet, J.-Y., Godthelp, H., Hand, S., Beck, R., 2009. Chulpasia and Thylacotinga, late Paleocene-earliest Eocene trans-Antarctic Gondwanan bunodont marsupials: new data from Australia. Geobios 42, 813-823.

Simpson, G.G., Paula-Couto, C.D., 1981. Fossil Mammals from the Cenozoic of Acre, Brazi III-Pleistocene Edentata Pilosa, Proboscidea, Sirenia, Perissodactyla and Artiodactyla. Iheringia 6 pp. 11-73.

Spillmann, F., 1949. Contribución a la paleontología del Perú: Una mamifauna fósil de la región del Río Ucayali. Publicaciones del Museo de Historia Natural Javier Prado 1 pp. 1-39.

Sterli, J., de la Fuente, M.S., 2013. New evidence from the Palaeocene of Patagonia (Argentina) on the evolution and palaeo-biogeography of Meiolaniformes (Testudinata, new taxon name). Journal of Systematic Palaeontology 11, 835-852.

Stirton, R.A., 1953. Vertebrate Paleontology and continental stratigraphy in Colombia. Bulletin of the Geological Society of America 64, 603-622.

Tejada-Lara, J.V., Salas-Gismondi, R., Pujos, F., Baby, P., Benammi, M., Brusset, S., De Franceschi, D., Espurt, N., Urbina, M., Antoine, P.-O., 2015. Life in Protoamazonia: Middle Miocene mammals from the Fitzcarrald Arch (Peruvian Amazonia). Palaeontology http://dx.doi.org/10.1111/pala.12147.

Tineo, D.E., Bona, P., Pérez, L.M., Vergani, G.D., González, G., Poiré, D.G., Gasparini, Z. Legarreta, P., 2015. Palaeoenvironmental implications of the giant crocodylian Mourasuchus (Alligatoridae, Caimaninae) in the Yecua Formation (late Miocene) of Bolivia. Alcheringa 39, 224-235.

Tschopp, H.J., 1953. Oil explorations in the Oriente of Ecuador, 1938-1950. AAPG Bulletin 37, 2303-2347.

Uba, C.E., Hasler, C.A., Buatois, L.A., Schmitt, A.K., Plessen, B., 2009. Isotopic, paleontologic and ichnologic evidence for late Miocene pulses of marine incursions in the central Andes. Geology 37, 827-830.

Vallejo-Pareja, M.C., Carrillo, D.J., Moreno-Bernal, J.W., Pardo-Jaramillo, M., RodriguezGonzalez, D.M., Muñoz-Duran, J., 2015. Hilarcotherium castanedai, gen. et sp. nov., a new Miocene astrapothere (Mammalia, Astrapotheriidae) from the Upper Magdalena Valley, Colombia. Journal of Vertebrate Paleontology 35. http://dx.doi.org/10. 1080/02724634.2014.903960.

Vandenberghe, N., Hilgen, F., Speijer, R., 2012. The Paleogene Period. In: Gradstein, F.M., Ogg, J.G., Schmitz, M., Ogg, G. (Eds.), The Geologic Time Scale 2012. Elsevier, pp. 855-921.

Vélez-Juarbe, J., 2014. Ghost of seagrasses past: using sirenians as a proxy for historical distribution of seagrasses. Palaeogeography, Palaeoclimatology, Palaeoecology 400, 41-49.

Vélez-Juarbe, J., Martin, T., MacPhee, R.D., Ortega-Ariza, D., 2014. The earliest Caribbean rodents: Oligocene caviomorphs from Puerto Rico. Journal of Vertebrate Paleontology 34, 157-163.

Vialle, N., Merzeraud, G., Delmer, C., Feist, M., Jiquel, S., Marivaux, L., Vianey-Liaud, M., E Mabrouk, E., Marzougui, W., Khayati Ammar, H., Tabuce, R., 2013. Discovery of an embrithopod mammal (Arsinoitherium?) in the late Eocene of Tunisia. Journal of African Earth Sciences 87, 86-92.

Vucetich, M.G., Bond, M., 2013. Un nuevo Octodontoidea (Rodentia, Caviomorpha) del Oligoceno tardío de la Provincia de Chubut (Argentina). Ameghiniana 21, 105-114.

Vucetich, M.G., Dozo, M.T., Arnal, M., Pérez, M.E., 2015. New rodents (Mammalia) from the late Oligocene of Cabeza Blanca (Chubut) and the first rodent radiation in Patagonia. Historical Biology 27, 236-257. 
Wallach, V., Williams, K.L., Boundy, J., 2014. Snakes Of The World: A Catalogue Of Living And Extinct Species. CRC Press.

Welker, F., Collins, M.J., Thomas, J.A., Wadsley, M., Brace, S., Cappellini, E., Turvey, S.T., Reguero, M., Gelfo, J.N., Kramarz, A., Burger, J., Thomas-Oates, J., Ashford, D.A., Ashton, P.D., Rowsell, K., Porter, D.M., Kessler, B., Fischer, R., Baessmann, C., Kaspar, S., Olsen, J.V., Kiley, P., Elliott, J.A., Kelstrup, C.D., Mullin, V., Hofreiter, M., Willerslev, E., Hublain, J.-J., Orlando, L., Barnes, I., MacPhee, R.D., 2015. Ancient proteins resolve the evolutionary history of Darwin's South American ungulates. Nature http://dx. doi.org/10.1038/nature14249.

Wesselingh, F.P., Ramos, M.I.F., 2010. Amazonian aquatic invertebrate faunas (Mollusca, Ostracoda) and their development over the past 30 million years. In: Hoorn, C., Wesselingh, F.P. (Eds.), Amazonia, Landscape and Species Evolution: A Look into the Past. Blackwell-Wiley, Hoboken, pp. 302-316.

Wesselingh, F.P., Räsänen, M.E., Irion, G., Vonhof, H.B., Kaandorp, R., Renema, W., Romero Pittman, L., Gingras, M., 2002. Lake Pebas: a palaeoecological reconstruction of a Miocene, long-lived lake complex in western Amazonia. Cainozoic Research 1, 35-81.

Wesselingh, F.P., Hoorn, M.C., Guerrero, J., Räsänen, M.E., Pittmann, L.R., Salo, J.A., 2006. The stratigraphy and regional structure of Miocene deposits in western Amazonia (Peru, Colombia and Brazil), with implications for late Neogene landscape evolution. Scripta Geologica 133, 291-322.

Willard, B., 1966. The Harvey Bassler Collection of Peruvian Fossils. Lehigh University.

Wing, S.L., Herrera, F.A., Jaramillo, C.A., Gomez, C., Wilf, P., Labandeira, C.C., 2009. Late Paleocene fossils from the Cerrejón Formation, Colombia, are the earliest record of Neotropical Rainforest. Proceedings of the National Academy of Sciences of the United States of America 106, 18627-18632.

Woodburne, M.O., Goin, F.J., Bond, M., Carlini, A.A., Gelfo, J.N., López, G.M., Iglesias, A., Zimicz, A.N., 2014. Paleogene land mammal faunas of South America; a response to global climatic changes and indigenous floral diversity. Journal of Mammalian Evolution 21, 1-73.

Woodward, H., 1871. The Tertiary shells of the Amazons valley. Annals and Magazine of Natural History 4 (59-64), 101-109.

Yeo, D., Cumberlidge, N., Klaus, S., 2014. Advances in freshwater decapod systematics and biology. Crustaceana Monographs 19. Brill, Leiden.

Zárate, M.A., Schultz, P.H., Blasi, A., Heil, C., King, J.Y., Hames, W., 2007. Geology and geochronology of type Chasicoan (late Miocene) mammal-bearing deposits of Buenos Aires (Argentina). Journal of South American Earth Sciences 23, 81-90.

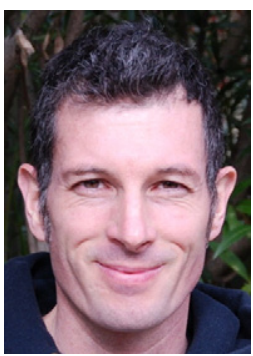

Pierre-Olivier Antoine is a Professor of Paleontology at the University of Montpellier, France. He has a PhD from the Muséum National d'Histoire Naturelle, Paris and he was formerly Associate Professor in the University of Toulouse, France. His research was primarily devoted to Cenozoic mammal evolution, combining phylogenetic analyses and fieldwork in remote areas from Eurasia and South America. Major focuses of his current research are balanced between Cenozoic stratigraphy, biochronology, and paleogeography in Eurasia, and Proto-Amazonian biodiversity and ecosystem dynamics in South America. He has participated in more than 40 field expeditions in Pakistan, Turkey, Peru, and Bolivia.

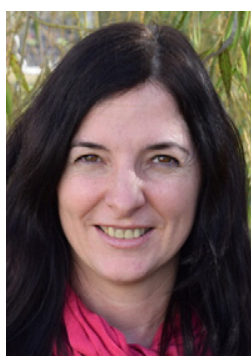

M. Alejandra Abello is a Researcher at the Consejo Naciona de Investigaciones Científicas (CONICET) from Argentina and Assistant Professor of the Unidad Paleontología Vertebrados at the Universidad Nacional de La Plata (UNLP), Argentina. She obtained a PhD from UNLP in 2007 with a study on the evolution of paucituberculatan marsupials. Her research mainly focuses on the systematics of South American metatherians, but her interests also include biogeographical and paleoecological approaches to better understand the evolution of these groups. She has participated in several paleontological expeditions in Argentina, Bolivia and Antarctica.

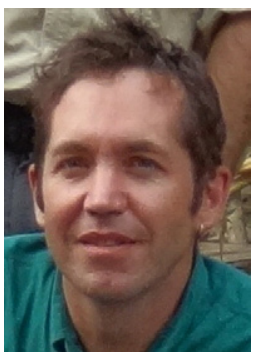

Sylvain Adnet is a vertebrate paleontologist in the Institute of Evolutionary Sciences of Montpellier and Associate Professor at the University of Montpellier, France. His research focuses mainly on shark, skate and ray evolution, with a special emphasis on their long-term dispersal dynamics and diversity in Cenozoic tropical marine realms.

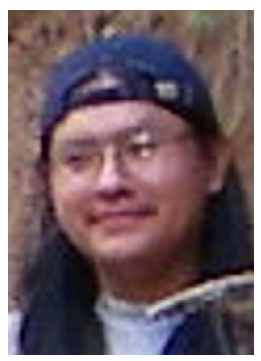

Alí J. Altamirano Sierra is a paleontologist devoted to anatomy and paleobiology of both birds and sharks. He is a research associate at the Vertebrate Paleontology Department of the San Marcos University Natural History Museum in Lima, Peru. His fieldwork takes place mostly on the Pacific coast of Peru, but he has also performed research in Peruvian Amazonia.

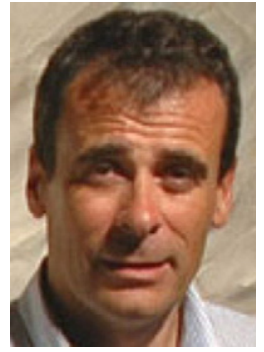

Patrice Baby is a geologist. He is Research Director at the Institute for Research and Development. He has a PhD in Earth sciences from the University of Toulouse, France. His works focus mainly on Andean, Subandean, and Amazonian geodynamics. In the last 20 years, he has cooperated with academic and industrial institutions in Bolivia, Peru, and Ecuador. In the last decade, he has also been working with biologists and paleontologists on the tectonic control of the diversification of biota in Western Amazonia. In particular, he has launched the multidisciplinary research group primarily coinciding with the coauthors of this review, and led several geological-paleontological expeditions in Amazonia.

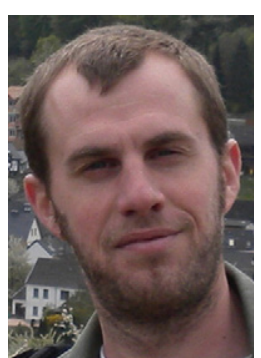

Guillaume Billet is an Associate Professor at the Muséum National d'Histoire Naturelle, Paris, France. After obtaining a $\mathrm{PhD}$ from the same Institution, he was an assistant lecturer in the University of Poitiers, France, and a postdoctoral researcher in the University of Bonn, Germany. His research in the macroevolutionary field is applied to extant and fossil morphological diversity of placental mammals endemic to South America during the Cenozoic. Specific questions he addresses on these groups especially relate to the links between the described patterns of morphological variation and phylogenetic, functional and architectural factors.

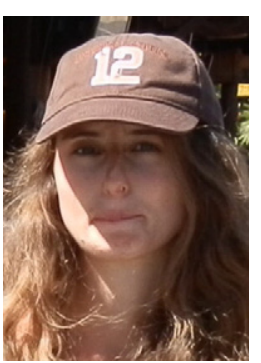

Myriam Boivin is a PhD student and teaching assistant at the University of Montpellier, France, supervised by PierreOlivier Antoine and Laurent Marivaux. Her works focus on morphology, phylogeny, and paleobiogeography of Paleogene caviomorph rodents from Peruvian Amazonia.

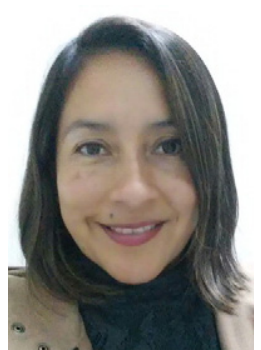

Ysabel Calderón is a geologist working at PERUPETRO, Private Law State Company of the Energy and Mines Peruvian Sector. Since joining PERUPETRO in 2000, she evaluated new plays and promoted areas in different basins of Peru (Offshore and Onshore basins). Also, she is a PhD student at Géosciences-Environnement Toulouse in Paul Sabatier University, France, funded by the Institut de Recherche pour le Développement. She obtained a Master degree in Geology from the same university. Her research has been focused on structural architecture, sedimentary evolution and hydrocarbon potential in a wedge-top foredeep zone in the northern Peruvian subandean basins.

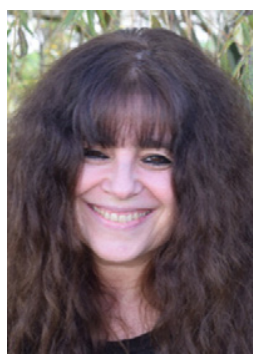

Adriana Candela is an Independent Researcher of CONICET (Consejo Nacional de Investigaciones Científicas) and Professor at the UNLP (Universidad Nacional de La Plata). Most of her research focuses on systematics, evolution, morphofunctional, and paleobiological studies of caviomorph rodents. She has also conducted investigations on Paleogene faunas of extinct lineages of South American metatherian mammals. More recently, she has started a new line of research on bio-chronostratigraphic issues, structure, and evolution of the Late Cenozoic mammalian communities of northwestern Argentina. 


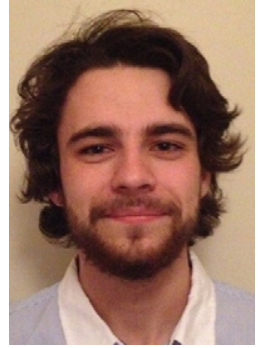

Jules Chabain recently obtained an MSc degree in Paleontology at the University of Montpellier, France. His works focus on taxonomy, evolution, and diversity of the Cenozoic ichthyofauna from Western Amazonia. His main interests are palaeoecology, zoology, and geology.

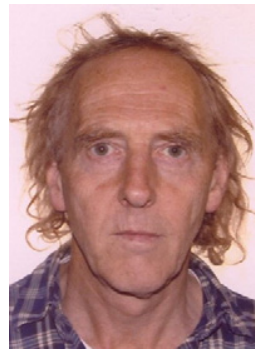

Fernando Corfu is a professor at the University of Oslo. He has a $\mathrm{PhD}$ from the $\mathrm{ETH}$, Zürich, and has been researcher at the Royal Ontario Museum in Toronto. He is specialized in ID-TIMS U-Pb geochronology applied to a variety of geological problems, primarily, but not exclusively, dealing with tectonics and orogeny throughout Earth history.

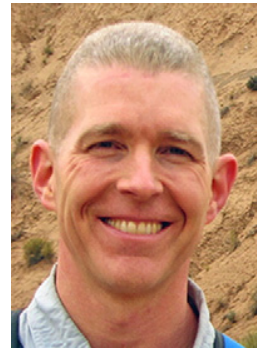

Darin A. Croft is an Associate Professor in the Department of Anatomy at Case Western Reserve University (Cleveland, Ohio), where he teaches human anatomy to medical and graduate students and investigates the extinct mammals of South America. He received his B.A. from The University of Iowa and his M.S. and Ph.D. from The University of Chicago. He has ongoing field programs in Chile and Bolivia, and his studies span alpha taxonomy, phylogenetics, paleoecology, and macroecology. Much of his research focuses on a group of endemic (and now extinct) herbivores known as notoungulates.

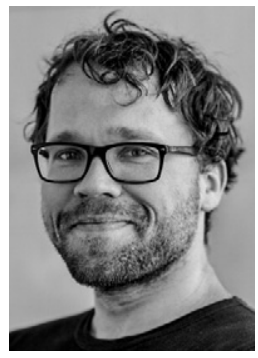

Morgan Ganerød is a geochronologist and paleomagnetist currently employed as a researcher at the Geological Survey of Norway (NGU). He obtained a PhD from the Norwegian University of Science and Technology in 2010 focusing on eruption timescales of Large Igneous Provinces (LIPS). He worked as a postdoctoral researcher in the noblegas laboratory at NGU from 2010 to 2012 and since 2012 he was appointed head of the ${ }_{40} \mathrm{Ar} /{ }_{39} \mathrm{Ar}$ and the paleomagnetic laboratory. He has interests in all areas of argon geochronology and is currently involved in projects including geochronology of the Caledonian orogeny, gold mineralizations (Norway, Iran), timescales of LIP formations and thermal conditions at subduction zones.

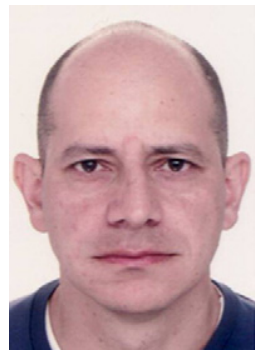

Carlos Jaramillo is a staff scientist with the Smithsonian Tropical Research Institute in Panama. His research investigates the causes, patterns, and processes of tropical biodiversity at diverse scales in time and space. Carlos is also interested in Mesozoic and Cenozoic biostratigraphy of low latitudes, developing methods for high-resolution biostratigraphy and the palaeobiogeography of Tethys.

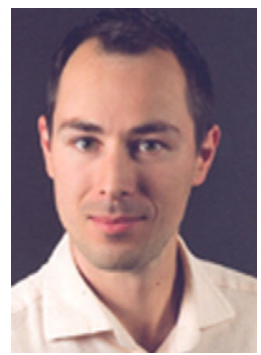

Sebastian Klaus is a group-leader at the Goethe-University, Frankfurt, Germany. He received his doctoral degree from Heidelberg University and worked on postdoctoral projects in Frankfurt, Singapore and Chengdu. He is interested in historical biogeography and evolution of aquatic organisms, with a focus on phylogeography, trait evolution and palaeontology of primary freshwater crabs.

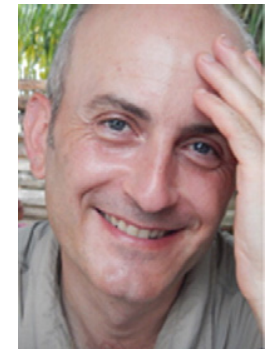

Laurent Marivaux is a CNRS researcher, paleontologist and head of the Paleontology Department at the "Institut des Sciences de l'Evolution de Montpellier". He has a PhD in Vertebrate Paleontology from the University of Montpellier. His research focuses on macroevolutionary, phylogenetic historical biogeography and paleobiological aspects of the early Tertiary adaptive radiations of some mammal groups (especially Rodentia, Primates, Dermoptera and Chiroptera, and others in collaboration), with a special emphasis on the role of the geodynamic and paleoenvironment changes on their emergence, dispersals and evolution. His is primarily a field paleontologist working in Paleo- and Neotropics.

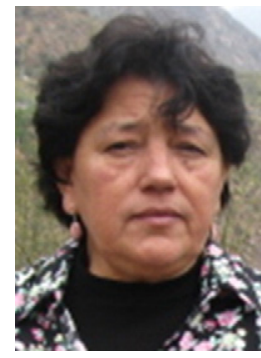

Rosa E. Navarrete is a $\mathrm{PhD}$ geologist, micropaleontologist and biostratigrapher, mainly focused on marine and terrestrial environments, tectonic - erosion, paleogeography and paleoclimate. She is much experienced in multidisciplinary biogeochronology (foraminifers, ostracods, calcareous nannofossils, molluscs, and palynostratigraphy) of the postPaleozoic interval in Americas, with emphasis on South American sedimentary basins. She is Chairwoman and research senior of biostratigraphy consulting Colombian company Paleosedes E.U. assessing Oil \& Gas industry over 25 years.

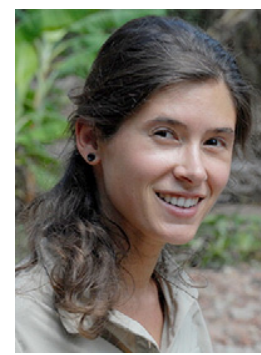

Maëva J. Orliac is a CNRS researcher at the University of Montpellier, France. She is a vertebrate paleontologist devoted to Cenozoic mammal evolution and phylogeny. She completed her undergraduate training and her $\mathrm{PhD}$ at the University Pierre et Marie Curie, in Paris. Her work primarily focused on the morphology and systematics of suoids (pigs and peccaries) and hippos, and their relationships within Artiodactyla. She is currently working on endocrania features of extinct and extant ungulates and primates, such as the middle and inner ear, and brain morphology. Recent fieldwork has taken her to Cenozoic deposits of Turkey and Peruvian Amazonia.

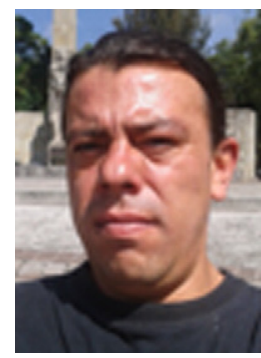

Francisco Parra has obtained a MSc Degree in Geology of Natural Resources at the University of Toulouse, France. He is currently a PhD student in co-tutorship at the University of Toulouse and the National University of Colombia, funded by the IRD. His experience mainly spans sedimentology and stratigraphy combining laboratory and field work with a focus in post-Paleozoic micropaleontology (foraminifers, ostracods, spores, pollen, dinoflagellates, and charophytes) biostratigraphy, paleogeography, paleoenvironmental analysis in Colombia and Peruvian Amazonia.

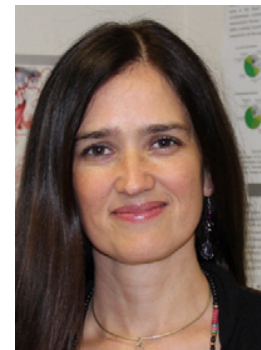

María Encarnación Pérez is a Researcher of CONICET at the Museo Paleontológico Egidio Feruglio of Trelew, Argentina, and Integrative Researcher at the Field Museum of Natura History of Chicago, USA. She has a PhD from the Universidad de La Plata and her research is focused in the evolutionary history of South American hystricognath rodents from a phylogenetic perspective. The research line includes the study of taxonomy, systematic, biogeography, and phylogeny of fossi and extant rodents, combining morphological and molecular data from many different sources of information (e.g. micro Ct scan, next generation sequencing).

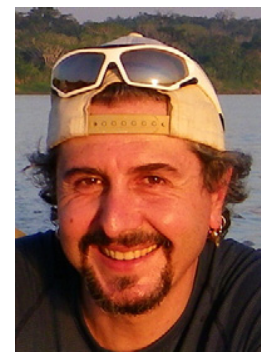

Francois Pujos is has received a $\mathrm{PhD}$ degree from the National Museum of Natural History of Paris. $\mathrm{He}$ is a former Researcher of the French Institute of Andean Studies and currently Researcher of the Argentinean Scientific and Technica National Research Councilin Mendoza. As a paleontologist focusing in systematics and evolution of South American Cenozoic mammals (e.g., Xenarthra), he has organized 25 field missions in South America and described new taxa, including several ground sloths. As a member of multidisciplinary teams, he has participated in the discovery of several new vertebrate communities from the Bolivian Altiplano and Peruvian Amazonia. 


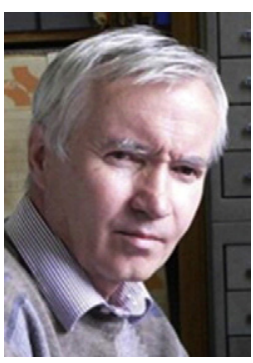

Jean-Claude Rage is an Emeritus Research Director of the CNRS (CR2P, CNRS-MNHN-UPMC) at the Muséum National d'Histoire Naturelle, in Paris, France. His major research interests lie in the evolution of lissamphibians and squamates, in paleobiogeography and in major paleobiological events (extinctions, radiations...). Most of his studies are devoted to the Cretaceous and Paleogene but his work is not restricted to this time interval.

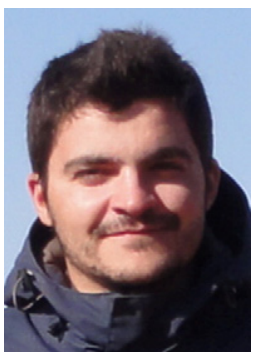

Anthony Ravel is a paleontologist devoted to the early evolutionary history of Chiroptera (bats), integrating systematic phylogenetic, paleobiogeographical and paleoecological aspects. He obtained a $\mathrm{PhD}$ from the University of Montpellier (France) focused on the origin and initial radiation of modern bats, with a special emphasis on new bat faunas from Eocene localities of North Africa and China. His current research project aims to better understand the emergence and evolution of echolocation within bat groups, thanks to the inner ear morphology of fossil bats.

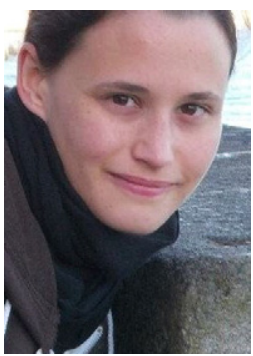

Céline Robinet is a $\mathrm{PhD}$ student at the Vertebrate Paleontology Division of the Museo de La Plata, Argentina. She has a Master's degree in Paleontology from the University of Montpellier, France. She has primarily worked on European Eocene mammals with a phylogenetic approach, before she was shortly hired as an engineer at the Institute of Evolutionary Sciences in Montpellier, France, working on Paleogene biodiversity and ecosystems of Peruvian Amazonia. Her research is now devoted to Cenozoic caviomorph rodents' paleoecology and evolution, under the supervision of Adriana Candela and Laurent Marivaux.

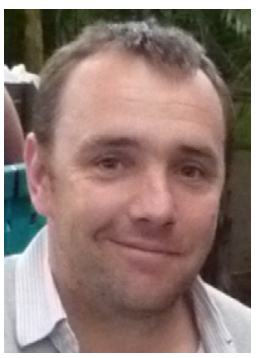

Martin Roddaz is an Associate Professor of geology in the University of Toulouse, France. His main scientific interests include the understanding on controls on sediment production, transport and deposition in the Andes-Amazon system at both short and geological timescales. He has participated in or led several field expeditions in the Amazon basin (Peru, Bolivia) since 2001. He is WP2 Leader of CLIM AMAZON project (Joint Brazilian-European facility for climate and geodynamic research on the Amazon River Basin sediments, http://www.clim-amazon.eu/).

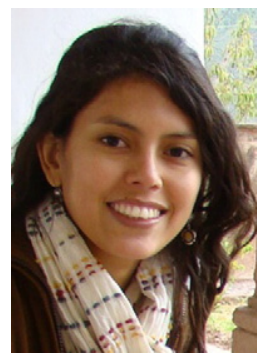

Julia Victoria Tejada-Lara is a PhD student at the Department of Earth and Environmental Sciences at Columbia University, New York. She holds a Master's degree from the Department of Zoology (University of Florida) and a BSc from the National University of San Marcos, Peru. She is Associate Researcher at the French Institute of Andean Studies and at the Natural History Museum in Lima, Peru. Her research has focused on the evolution of Cenozoic mammal communities and ecosystems from Proto-Amazonia and the Andean Plateau. Current research combines systematics, paleogeography, stable isotope geochemistry, and paleoecology of extinct and modern mammals from South America.

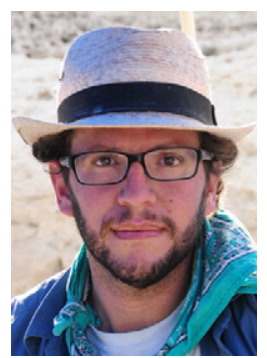

Jorge Vélez-Juarbe is the Assistant Curator of Marine Mammals at the Natural History Museum of Los Angeles County, California. He has a PhD from Howard University in Washington, DC, was formerly a Postdoctoral Researcher at the Florida Museum of Natural History and NSF Postdoctoral Fellow at California State University-Fullerton. His research primarily focuses on two subjects: the morphology, systematics and biology of fossil and extant marine mammals, and Cenozoic vertebrates of the Caribbean region. Combines lab work with fieldwork across the Americas and the Caribbean region.

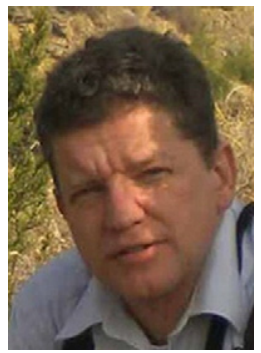

Frank P. Wesselingh is Senior Researcher with scientific curatorial responsibilities at Naturalis, Leiden, Netherlands. After a study in Earth Sciences at the Vrije Universiteit Amsterdam, he continued as a curator (later researcher) at Naturalis. At the same time he engaged in a PhD on Amazonian landscape and biota during the Neogene at the Biology faculty, Turku University, Finland. He tries to document and understand the drivers behind biodiversity changes in the geological past, especially the role of changing landscapes in driving community and biodiversity change, mostly focusing on mollusks from Indonesia, the North Sea, or the Pontocaspian region.

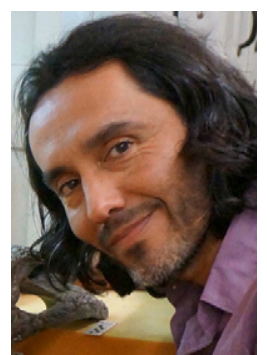

Rodolfo Salas-Gismondi is a $\mathrm{PhD}$ student at the Institut des Sciences de l'Evolution, University of Montpellier, France. He is founder and head of the Vertebrate Paleontology Department of the San Marcos University Natural History Museum in Lima, Peru. His research was primarily devoted to the evolution of South American vertebrates, mainly terrestrial and aquatic mammals (Pacific Coast, Andean highlands, and Amazonia). His current research is focused in the systematics, ecology, and evolution of the crocodylians from the Tertiary of Amazonia. 